\title{
GEOLOGY AND GEOTHERMAL RESOURCES OF THE SANTIAM PASS AREA OF THE OREGON CASCADE RANGE, DESCHUTES, JEFFERSON AND LINN COUNTIES, OREGON
}

DOE/ID/12834--13

\section{Final Report}

October 1992

RECEIVED

MAR 041993

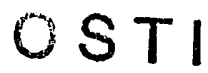

\section{DISCLAIMER}

This report was prepared as an account of work sponsored by an agency of the United States Government. Neither the United States Government nor any agency thereof, nor any of their employees, makes any warranty, express or implied, or assumes any legal liability or responsibility for the accuracy, completeness, or usefulness of any information, apparatus, product, or process disclosed, or represents that its use would not infringe privately owned rights. Reference herein to any specific commercial product, process, or service by trade name, trademark, manufacturer, or otherwise does not necessarily constitute or imply its endorsement, recommendation, or favoring by the United States Government or any agency thereof. The views and opinions of authors expressed herein do not necessarily state or reflect those of the United States Government or any agency thereof.

Work Performed Under Grant No. DE-FG07-89ID12834

For

U. S. Department of Energy

Office of Industrial Technologies

Washington, D.C.

By

State of Oregon

Department of Geolology and Mineral Industries

Portland, Oregon 97232 
STATE OF OREGON

DEPARTMENT OF GEOLOGY AND MINERAL INDUSTRIES

Suite 177

800 NE Oregon St., \#28

Portland, Oregon 97232

OPEN-FILE REPORT 0-92-3

GEOLOGY AND GEOTHERMAL RESOURCES OF THE SANTIAM PASS AREA

OF TKE OREGON CASCADE RANGE, DESCHUTES, JEFFERSON AND

LINN COUNTIES, OREGON

Edited by

Brittain E. Hill

Oregon Department of Geology and Mineral Industries

Portland, Oregon

1992

Funded in part by

U.S. Department of Energy

Grant No. DE-FG07-89 ID 12834 


\section{NOTICE}

This report was prepared with the support of the U.S. Department of Energy (DOE) Cooperative Agreement No. DE-FG07-89 ID 12834. However, any options, findings, conclusions, or recommendations expressed herein are those of the authors and do not necessarily reflect the views of DOE.

The Oregon Department of Geology and Mineral Industries is publishing this paper because the subject matter is soneisient with the mission of the Department. To facilitate timely distribution of information, camera-ready copy submitted by the editor has not been edited by the staff of the Oregon Department of Geology and Mineral Industries. 


\section{CONTENTS}

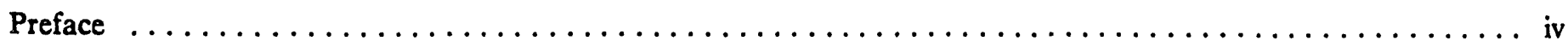

Chapter 1. Drilling history of the Santiam Pass 77-24 well, Cascade Range, Oregon,

by Brittain E. Hill and Dick Benoit $\ldots \ldots \ldots \ldots \ldots \ldots \ldots \ldots \ldots \ldots \ldots \ldots$

Chapter 2. Geologic setting of the Santiam Pass area, central Cascade Range, Oregon,

by Brittain E. Hill and George R. Priest $\ldots \ldots \ldots \ldots \ldots \ldots \ldots \ldots \ldots \ldots \ldots$

Chapter 3. Stratigraphy and petrology of the Santiam Pass 77-24 drill core, Cascade Range, Oregon,

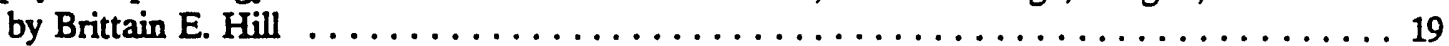

Chapter 4. Thermal results of the Santiam Pass 77-24 drill hole,

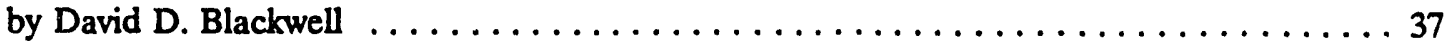

Appendix A. Description of analytical techniques used to determine the compositions of core and surface samples from the Santiam Pass area $\ldots \ldots \ldots \ldots \ldots \ldots \ldots \ldots \ldots \ldots \ldots \ldots \ldots$

Appendix B. Visual estimates of phenocryst abundances and additional petrographic information obtained from thin-sections of Santiam Pass $77-24$ core samples . . . . . . . . . . . 54

Appendix C. Major, minor, and trace element analyses of Santiam Pass 77-24 core, surface rocks

from the Santiam Pass area, and core from Unocal $82-1 \ldots \ldots \ldots \ldots \ldots \ldots 6$ 


\section{Preface}

The Santiam Pass study area is located about $140 \mathrm{~km}$ southeast of Portland, on the axis of the Oregon Cascade Range (Figure 1). Most of the study area is located in the High Cascades physiographic subprovince, which consists of relatively young, uneroded volcanic rocks. Older, more deeply incised terrane associated with the Western Cascade subprovince is exposed along the western part of the area. The High Cascades in Oregon represents an extensive, northsouth-trending arc of Quaternary volcanism related to oblique subduction of the Juan de Fuca oceanic plate beneath North America.

The northern and central parts of the Oregon Cascade Range have several geologic features commonly associated with geothermal resources. Large composite volcanoes such as Mount Jefferson, South Sister, and Mount Hood (Figure 1) contain numerous silicic flows and domes and have been active for 100,000 years (South Sister; Hill, 1991) to at least 1,000,000 years (Mount Jefferson; Conrey, 1991), with evidence for Holocene eruptions at all these volcanoes. Holocene and late Pleistocene mafic volcanism also extends the length of the Oregon Cascades arc. The Oregon Cascade Range is characterized by east-west extension and late Tertiary graben subsidence, which may allow for deep circulation of geothermal fluids. Much of this area also lies within a zone of anomalously high heat flow, which ranges from 100 milliwatts per square meter $\left(\mathrm{mW} / \mathrm{m}^{2}\right)$ to more than $120 \mathrm{~mW} / \mathrm{m}^{2}$ (Blackwell and others, 1982, 1990). Known Geothermal Resource

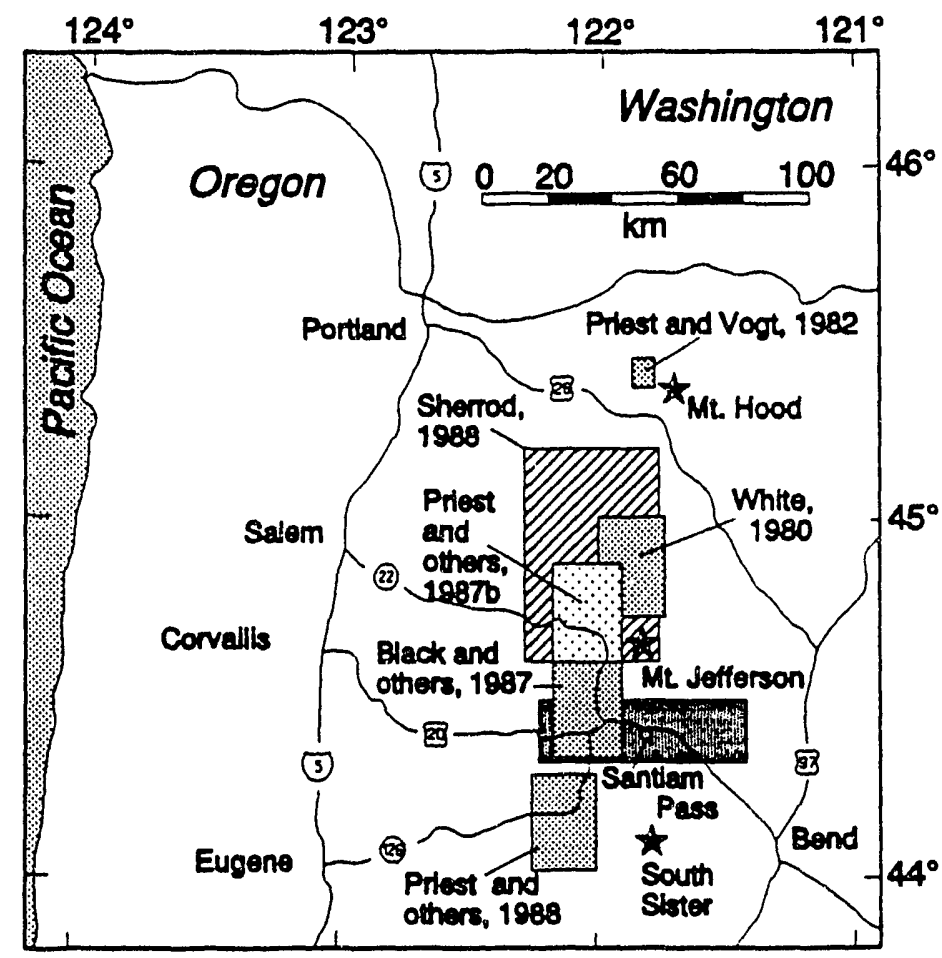

Figure 1. Index map showing the location of the Santiam Pass study area and locations of other DOGAMI-sponsored geothermal investigations in the central and northem Cascade Range of Oregon. Also shown are major towns, highways and Quatemary composite volcanoes. 
Areas are also located at Mount Hood (Priest and Vogt, 1982), $\approx 25 \mathrm{~km}$ northwest of South Sister at Belknap-Foley Hot Springs (Priest and others, 1988), and $\approx 20 \mathrm{~km}$ northwest of Mt. Jefferson at Breitenbush Hot Springs (Sherrod, 1988). However, estimates of geothermal resource potential in the Oregon Cascades are poorly constrained (Muffler and Guffanti, 1989), owing to inadequate subsurface data. Previous geothermal studies (Figure 1) have focused on known thermal features or have been located adjacent to large composite volcanoes. There also have been few intermediatedepth drilling programs to calibrate geothermal, geophysical and geological models of the Oregon High Cascades.

This open-file report presents the results of the Santiam Pass drilling program. The first phase of this program was to compile all available geological, geophysical and geothermal data for the Santiam Pass area and select a drill site on the basis of these data (see Priest and others, 1987a). A summary of the drilling operations and costs associated with the project are presented in chapter 1 by Hill and Benoit. An overview of the geology of the Santiam Pass area is presented by Hill and Priest in chapter 2. Geologic mapping and isotopic age determinations in the Santiam Pass-Mount Jefferson area completed since 1987 are summarized in chapter 2. One of the more important conclusions reached in chapter 2 is that a minimum of $2 \mathrm{~km}$ vertical displacement has occurred in the High Cascade graben in the Santiam Pass area.

The petrology of the Santiam Pass drill core is presented by Hill in chapter 3. Most of the major volcanic units in the core have been analyzed for major, minor, and trace element abundances and have been studied petrographically. Three K-Ar ages are interpreted in conjunction with the magnetostratigraphy of the core to show that the oldest rocks in the core are approximately $1.8 \mathrm{Ma}$. Hydrothermal alteration of the core is minimal, and is characterized by weak clay \pm chlorite \pm zeolite alteration in the lower $200 \mathrm{~m}$ of the core. Geochemical comparisons of the Santiam Pass core to other Quaternary and Miocene Cascade mafic rocks show no petrogenetic distinctions between rocks from these different ages.

Geothermal and geophysical data collected from the Santiam Pass well are presented by Blackwell in chapter 4. The Santiam Pass well failed to penetrate beneath the zone of lateral groundwater flow associated with highly permeable Quaternary volcanic rocks. The geothermal gradient in the well is essentially isothermal to $700 \mathrm{~m}$, and it is disturbed by downward flow in the well to almost $900 \mathrm{~m}$. Calculated geothermal gradients range from about $50^{\circ} \mathrm{C} / \mathrm{km}$ at depth 700 $900 \mathrm{~m}$, to roughly $110^{\circ} \mathrm{C} / \mathrm{km}$ from $900 \mathrm{~m}$ to the bottom of the well at $929 \mathrm{~m}$. Heat-flow values for the bottom part of the hole bracket the regional average for the High Cascades. Blackwell concludes that heat flow along the High Cascade axis is equal to or higher than along the western edge of the High Cascades.

\section{ACKNOWLEDGMENTS}

Financial support for this open-file report comes from U.S. Department of Energy Grant DE-FG07-89ID12834 to the Oregon Department of Geology and Mineral Industries. The University of Utah Research Institute provided funding for the three radioactive ages of the SP- 77-24 drill core and contributed quantitative whole-rock analyses. The Santiam Pass drilling would not have been possible without a major cost-sharing arrangement with Oxbow Power Company and the assistance of Dick Benoit. I also thank George Priest, Edward Taylor, Dave Sherrod, Steve Ingebritsen, Jerry Black, Beverly Vogt, and Klaus Neuendorf for their assistance in the preparation of this report. 


\section{REFERENCES CITED}

Blackwell, D.D., Bowen, R.G., Hull, D.H., Riccio, J., and Steele, J.L., 1982, Heat flow, arc volcanism, and subduction in northern Oregon: Journal of Geophysical Research, v. 87, p. 8,735-8,754.

Blackwell, D.D., Steele, J.L, Frohme, M.K., Murphey, C.F., Priest, G.R., and Black, G.L., 1990, Heat flow in the Oregon Cascade Range and its correlation with regional gravity, Curie point depths, and geology: Journal of Geophysical Research, v. 95 , p. $19,475-19,493$.

Conrey, R.M, 1991, Geology and petrology of the Mt. Jefferson area, High Cascade Range, Oregon: Pullman, Washington State University, Ph.D. dissertation, $357 \mathrm{p}$.

Hill, B.E., 1991, Petrogeresis of compositionally distinct silicic volcanoes in the Three Sisters region of the Oregon Cascade Range: The effects of crustal extension on the development of continental arc silicic magmatism: Corvallis, Oregon State University, Ph.D. dissertation, 235 p.

Muffier, L.J.P., and Guffanti, M., 1989, Integration of earth-science data sets to estimate undiscovered geothermal resource of the Cascade Range, in Muffler, L.J.P., Weaver, C.S., Blackwell., D.S., eds., Geological, geophysical, and tectonic setting of the Cascade Range: U.S. Geological Survey Open-File Report 89-178, p. 695-703.

Priest, G.R., Bargar, K.E., Black, G.R., Blackwell, D.D., Couch, R.A., Duncan, R.A., Evans, J., Goldstein, N., Haimson, B.C., Hughes, S., Iyer, M., Keith, T.E.C., Korosec, M.A., Laul, J.C., Levy, S., Mariner, R.H., Mooney, W.D., Rowley, J., Sherrod, D.R., Smith, M., Waibel, A., Weaver, C.S., Woller, N.M., and Wright, P.M., 1987a, Investigation of the thermal regime and geologic history of the Cascade volcanic arc: First phase of a program for scientific drilling in the Cascade Range: Oregon Department of Geology and Mineral Industries Open-File Report O-86-3, $120 \mathrm{p}$.

Priest, G.R., Black, G.L., Woller, N.M., and Taylor, E.M., 1988, Geologic map of the McKenzie Bridge quadrangle, Lane County, Oregon: Oregon Department of Geology and Mineral Industries Map GMS-48, scale 1:62,500.

Priest, G.R., Woller, N.M, and Ferns, M.L., 1987b. Geologic map of the Breitenbush River area, Linn and Marion Counties, Oregon: Oregon Department of Geology and Mineral Industries Map GMS-46, scale 1:62,500.

Priest, G.R., and Vogt, B.A., eds., 1982, Geology and geothermal resources of the Mount Hood area, Oregon: Oregon Department of Geology and Mineral Industries Special Paper 14, 100 p.

Sherrod, D.R., ed., 1988, Geology and geothermal resources of the Breitenbush-Austin Hot Springs area, Clackamas and Marion counties, Oregon: Oregon Department of Geology and Mineral Industries Open File Report O-88-5, 91 p.

White, C., 1980, Geology of the Breitenbush Hot Springs quadrangle, Oregon: Oregon Department of Geology and Mineral Industries Special Paper 9, 26 p. 


\title{
Chapter 1
}

\section{Drilling history of the Santiam Pass 77-24 well, Cascade Range, Oregon}

by Brittain E. Hill, Oregon Department of Geology and Mineral Industries, Portland, Oregon 97232, and Dick Benoit, Oxbow Geothermal Corporation, Suite 450, 200 Virginia Street, Reno, Nevada 89501

\begin{abstract}
The Santiam Pass drilling program was designed to investigate the thermal regime and geologic history of the central part of the Oregon Cascade Range. To accomplish this goal, a 929-m-deep well was drilled into Quaternary volcanic rocks on the axis of the High Cascades. Drilling was completed in two phases. The upper $140 \mathrm{~m}$ of the well were completed through 8 days of rotary drilling during November, 1989, at a total cost of $\$ 29,710$. Diamond-core drilling from $140 \mathrm{~m}$ to $929 \mathrm{~m}$ depth required 29 days during August and September, 1990. No significant delays occurred during drilling, and diamond-core drilling costs totalled \$194,260. Although mud circulation was lost between 160-920 m, 99.7 percent of the core was recovered. Water-filled black pipe was run to $929 \mathrm{~m}$ in the well after circulation of completion mud for roughly three hours.
\end{abstract}

\section{INTRODUCTION}

Since 1979 the U.S. Department of Energy (DOE) has partially funded the Oregon Department of Geology and Mineral Industries (DOGAMI) for geothermal resource assessment activities. In 1989, DOE awarded grant DE-FG0789ID12834 to DOGAMI as part of the Geothermal Research, Development, and Demonstration Act of 1984. The principal objective of this grant was to obtain temperature gradient, heat flow, and hydrologic information along the axis of Cascade volcanism away from major silicic volcanoes; earlier deep ( $\geq 150 \mathrm{~m}$ ) drilling in the Cascade Range only tested local thermal features associated with major volcanic complexes. In an effort to support geothermal studies in the Oregon Cascade Range, Oxbow Power Corporation agreed to contribute a minimum one-third share of the drilling costs.

\section{DRILLING OPERATIONS}

The Santiam Pass 77-24 well was drilled in two phases, beginning in October, 1989. The well site occupies a roughly $15-\mathrm{m}$ by $35-\mathrm{m}$ previously cleared area located approximately $100 \mathrm{~m}$ south of U.S. Highway 20 , along Forest Road 900 (Plate 1). This site was chosen for ease of access for heavy equipment and to minimize impact on the surrounding forest. Initial site preparation consisted of removing logging debris from the site, minor leveling of the site, and digging a mud pit 3-m by $2-\mathrm{m}$ by $2-\mathrm{m}$-deep. The upper $140 \mathrm{~m}$ of the hole were rotary drilled by Woytec Drilling Company between 31 October and 8 November, 1989. The first $11 \mathrm{~m}$ of the hole were drilled and cased with $25.5-\mathrm{cm}$ inner-diameter surface 
conductor, which was then cemented into the hole. Drilling continued at a rate of about 30 meters per day with a $22.2-\mathrm{cm}$ button bit to $119 \mathrm{~m}$ and a $20-\mathrm{cm}$ button bit to $140 \mathrm{~m}$. Circulation of water and foam was maintained throughout most of the rotary drilling, and rock chip samples were collected every $3 \mathrm{~m}$. The 140-m-deep hole was then conditioned with drilling mud, and a $10.2-\mathrm{cm}$ inner diameter conductor was successfully cemented in the hole from the surface to $140 \mathrm{~m}$. Total costs for the upper $140 \mathrm{~m}$ of the well were $\$ 29,710$.

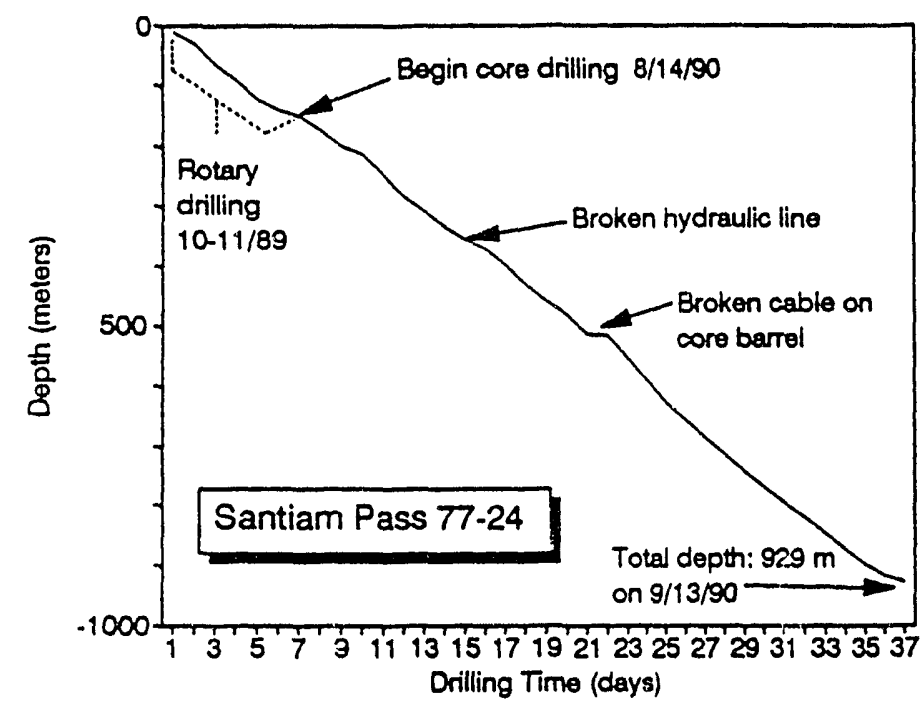

Figure 1-1. Drilling rate (depth per day) for Santiam Pass 77-24.
Diamond-core drilling by Tonto Drilling Services between 10 Augrst and 17 September, 1990, followed additional site leveling and minor clearing to position the drill rig. Rig set-up combined with installation and testing of the blow-out preventer assembly took 3 days; drilling commenced on 14 August. The hole was drilled from $140 \mathrm{~m}$ to a total depth of $929 \mathrm{~m}$ using HQ (10.2-cm outer diameter) diamond core rods, with 99.7 percent core recovery. Mud circulation was intermittent between $140 \mathrm{~m}$ and $188 \mathrm{~m}$, in spite of the addition of cottonseed hulls, mud polymer, mud sealant, and paper fiber; circulation was lost completely between $188 \mathrm{~m}$ and $929 \mathrm{~m}$. Drilling proceeded at an average rate of 28 meters per day with only two minor delays owing

to a broken hydraulic line and a parted cable on the core barrel (Figure 1-1).

Table 1-1. Summary of drilling costs for Santiam Pass 77-24

\begin{tabular}{lr}
\hline Rotary drilling & $\$ 29,710$ \\
Mobilization and demobilization of core rig & $\$ 10,010$ \\
Blow-out preventer rental & $\$ 15,464$ \\
Rig hours, footage, and additional labor & $\$ 136,082$ \\
Equipment rental & $\$ 9,570$ \\
Bits, mud, and grease & $\$ 14,323$ \\
938 m of 4.8 cm black pipe & $\$ 4,416$ \\
Misc. supplies, phone, and disposal service & $\$ 4,395$ \\
& $\$ 223,970$
\end{tabular}

Heavy completion muc was circulated in the 929-m-deep hole for about three hours, and a closed-end, water-filled 4.8-cm inner-diameter schedule-40A black pipe was run to $929 \mathrm{~m}$ through the HQ core rods on 15 September, 1990. During subsequent removal of the HQ rods from the hole an attachment used to suspend the drill rods in the hole failed, resulting in $915 \mathrm{~m}$ of drill string falling about $15 \mathrm{~m}$ to the bottom of the hole. The impact of the rods

broke 3 teeth off of the HQ rod shoe at the bottom of the hole but did not damage the water-filled black pipe. An initial decline in the water level of approximately $30 \mathrm{~cm}$ occurred in the pipe during the first 24 hours, with an additions! decline of several meters during the next 10 days. Total costs for the core drilling were $\$ 194,260$ (Table 1-1) and averaged $\approx \$ 250$ per meter (\$76 per foot). 


\section{Drilling history of the Santiam Pass 77-24 well}

\section{ACKNOWLEDGMENTS}

The funding for this project would not have been possible without the effort and support of George Priest, Don Hull, and John Beaulieu (DOGAMI); Douglas Powell and Lori Orser (Oxbow Power Corporation); and Ken Osborne and Peggy Brookshire (DOE). The drilling of the Santiam Pass well was successful due to the professionals at Woytec Drilling, Sparks, Nevada, and Tonto Drilling Services, Salt Lake City, Utah. We also thank Donna Owens of the U.S. Forest Service, Sisters Ranger District, and Dennis Davis of the Bureau of Land Management, Prineville District, for their assistance. 


\title{
Chapter 2
}

\section{Geologic setting of the Santiam Pass area, central Cascade Range, Oregon}

by Brittain E. Hill and George R. Priest, Oregon Department of Geology and Mineral Industries, Portland, Oregon 97232

\begin{abstract}
An understanding of the geolngy of the Santiam Pass area is necessary to evaluate the geothermal and lithologic data obtained from the Santiam Pass drilling program. The oldest rocks in the Santiam Pass area are hydrothermally altered volcanic and volcaniclastic rocks older than about $8 \mathrm{Ma}$, which are conventionally assigned to the Western Cascades subprovince. Vents for these rocks are exposed as far as $30 \mathrm{~km}$ west of the present volcanic axis of the Cascade Range, and some vents are exposed east of the axis. Rocks older than $8 \mathrm{Ma}$ are unconformably overlain by approximately 7-5 Ma unaltered mafic ( $\mathrm{SiO}_{2}$ less than 58 percent) flows, which were erupted from vents coincident with the present High Cascades axis and from the eastern margin of the Western Cascades. A north-trending intra-arc graben developed in the Santiam Pass area abov s iva, coincident with a period of uplift in the Western Cascades. Graben formation resulted in at least $1 \mathrm{~km}$ and possibly $3 \mathrm{~km}$ of net vertical displacement in the Santiam Pass area. The topographic low created by formation of the graben was mostly filled by volcanic and sedimentary rocks from 5 to 2 Ma. Volcanism since about 2 Ma has been predominantly mafic, with eruptions as recently as 3,000 years ago in the Santiam Pass area.

Tho central part of the Oregon Cascade Range is characterized by anomalously high heat flow, which locally exceeds $100 \mathrm{~mW} / \mathrm{m}^{2}$. The relationship between Cascade volcanism and geothermal resource potential is unclear, because regional heat-flow anomalies extend well beyond the boundaries of post-1 Ma volcanism, and local thermal features are not always associated with long-lived silicic volcanoes. The Santiam Pass drilling program was designed primarily to investigate the extent and nature of background heat flow in a part of the active Cascades arc away from large stratovolcanoes or silicic centers. The drill hole also provides important subsurface geological and geophysical information, which aids in understanding the geologic history of the area and the influence of physical properties of rocks on temperature gradients.
\end{abstract}

\section{INTRODUCTION}

This chapter describes the general geologic setting of the Santiam Pass area of the Oregon Cascade Range, where volcanism and tectonism in the last $10 \mathrm{~m} . y$. have produced a diversity of geologic features. The Santiam Pass drilling program provides additional constraints on the geologic history of this area. Recent papers by Priest and others (1983), 
Sherrod and Conrey (1988), Taylor (1990) and Priest (1990) summarize the general geology in the central Oregon Cascade Range and provide much of the information in this chapter.

\section{Western Cascades}

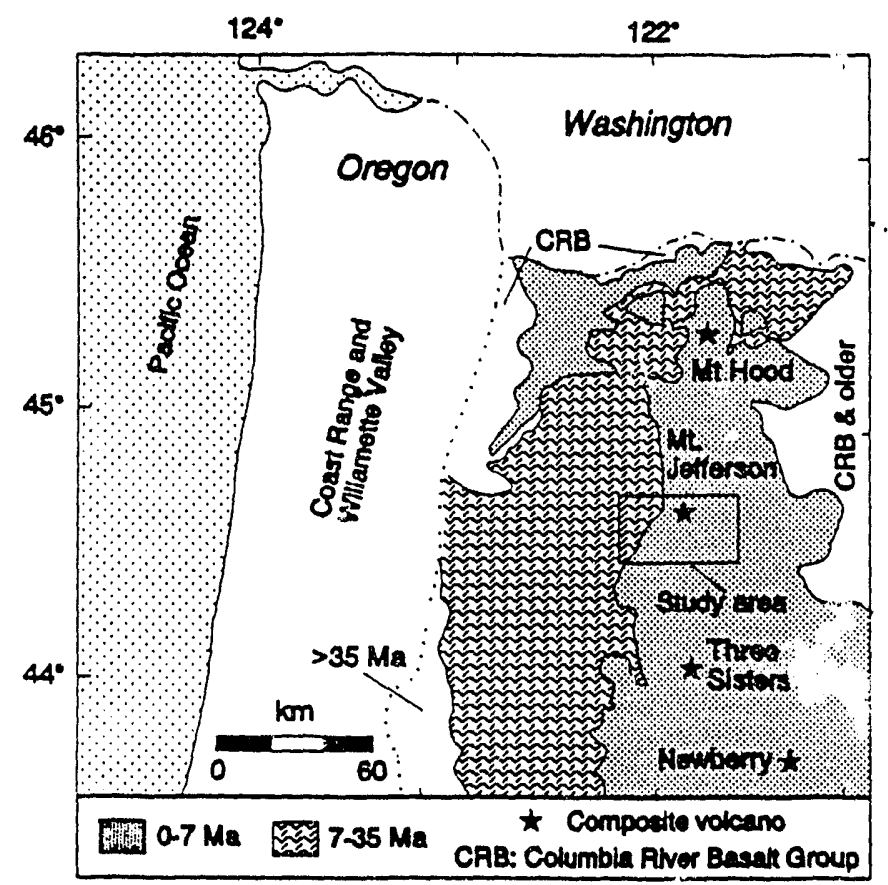

Figure 2-1. Generalized geologic map showing the distribution of Oregon Cascade rocks. Study area is the Santiam Pass area, which is shown in detail in Figure 2.2. Modified from Sherrod and Smith (1989).
The Oregon Cascade Range can be divided into two physiographic subprovinces (Callaghan, 1933), commonly referred to as the Western Cascades and High Cascades (Figure 2-1). A combination of time- and rockstratigraphic units is generally used to further subdivide these provinces (Peck and others, 1964; Priest and others 1983; Sherrod and Smith, 1989; Priest, 1990). Early Western Cascades rocks range in age from about $35 \mathrm{Ma}$ to about $17 \mathrm{Ma}$ and are characterized by local andesitic volcanoes along with voluminous eruptions of tholeiitic lavas and silicic pyroclastic rocks (White and McBirney, 1978; Priest, 1990; Taylor, 1990). Many early Western Cascades rocks are hydrothermally altered. Zeolitic to low-grade propylitic alteration is ubiquitous, with tuffaceous rocks more strongly altered than lava flows (Priest and others, 1983). Early Western Cascades volcanism likely ended with a period of uplift and diminished volcapic activity from about $17 \mathrm{Ma}$ to about $14 \mathrm{Ma}$ (Priest and others, 1983).

Late Western Cascades rocks, which were produced from about $17 \mathrm{Ma}$ to about $8 \mathrm{Ma}$, unconformably overlie early Western Cascades units. Late Western Cascades rocks are characterized by two-pyroxene andesite lavas, with subordinate amounts of basaltic to dacitic lavas and pyroclastic rocks (Priest and others 1983; Sherrod and Smith, 1989). Both early and late Western Cascades rocks generally dip $0^{\circ}-10^{\circ}$ eastward (Walker and Duncan, 1989; Priest, 1990) but are locally disrupted by extensive faulting and slumping. Many late Western Cascades volcanic and subvolcanic rocks have been hydrothermally altered (Priest and others, 1983). Alteration ranges from pervasive low-grade zeolite-clay alteration of late Western Cascades lavas to high-grade potassic alteration in some subvolcanic intrusions (Peck and others, 1964; Priest and others, 1983; Power, 1984; Keith, 1988; Cummings and others, 1990).

Late Western Cascades rocks are vell exposed approximately $30 \mathrm{~km}$ west of the Santiam Pass well site (Figures 2-1 and 2-2). These rocks consist primarily of andesitic lavas and pyroclastic deposits, with subordinate amounts of basaltic to dacitic lavas (Black and others, 1987; Priest and others, 1987b). Northeast of Santiam Pass, 9-8-Ma andesitic rocks are exposed in the Castle Rocks area (Hales, 1974; Conrey, 1985; Wendland, 1988). In addition, about 15-Ma silicic pyro 


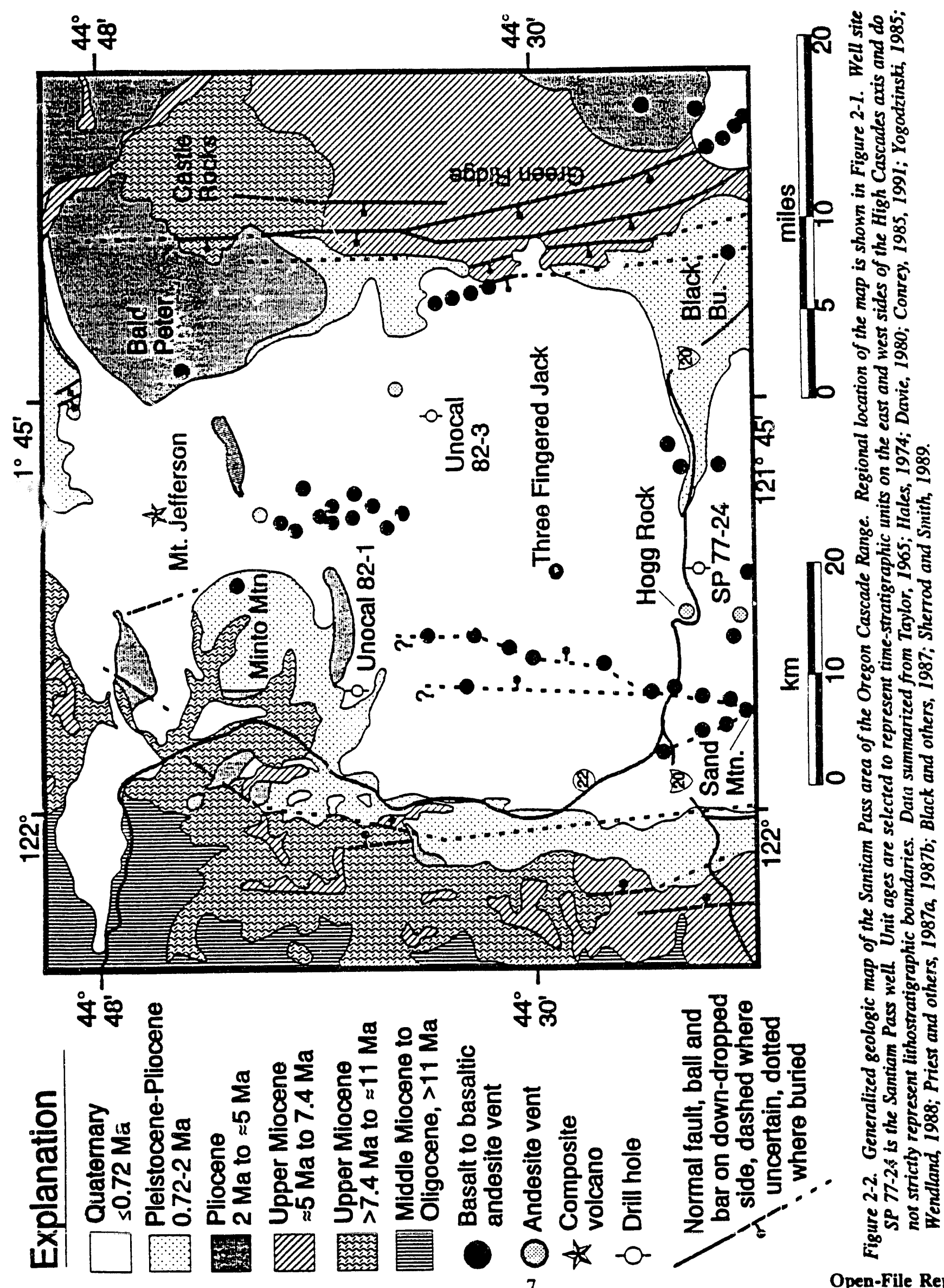

Open-File Report 0-92-3 


\section{Hill and Priest}

clastic units derived from late W'esiern Cascades volcanoes are preserved as the Simtustus Formation in the Deschutes Basin (Hayman, 1983; Smith, 1986a).

\section{Early High Cascades}

Early High Cascades volcanism began around 7.4 Ma and was centered on a volcanic axis essentially coincident with the axis of the present High Cascades (Taylor, 1981; Conrey, 1985; Smith and others, 1987). West of th igh Cascade axis, early High Cascades rocks are characterized by essentially subhorizontal mafic flows that cap many ridges (Taylor, 1981; Priest and others, 1983). These mafic flows are commonly diktytaxitic and have only minor amounts of clay replacing ferromagnesian phenocrysts (Priest and others, 1983; Taylor, 1981, 1990). Only a few pyrociastic rocks are exposed in early High Cascades sections west of the High Cascades axis (Priest and others, 1987b, 1988. 7 ylor, 1990). East of the High Cascades axis, abundant 7-5-Ma pyroclastic and volcaniclastic rocks are preserved as the Deschutes Formation (Taylor, 1981; Smith, 1986b; Co:rey, 1985; Smith and others, 1987). The formation of an intra-arc graben about 5.4 Ma (Taylor, 1981; Smith, 1986b; Smith and others, 1987) localized deposition of volcanic rocks within the graben, although eruptions associated with early High Cascades volcanoes likely continued to at least 4 Ma (Yogodzinski, 1985; Smith, 1986b; Smith and others, 1987 ).

The origin and extent of the High Cascades graben has been the focus of many geological studies (Callaghan, 1933; Allen, 1966; Taylor, 1981; Couch and others, 1982; Smith and Taylor, 1983; Priest and (thers, 1983; Keach and others, 1989; Livelybrooks and others, 1989; Smith and others, 1989; Priest, 1990; Taylor, 1990). One of the goals of the Santiam Pass drilling project is to provide additional data on the exten: of pre- and post-graben rocks beneath the axis of the High Cascades. Previous work by Priest and others (1987b, 1988) and Black and others, (1987) has shown that the western boundary of the graben has a minimum vertical displacement of about $600 \mathrm{~m}$ along north-striking normal faults in the area west and southwest of Santiam Pass. However, these graben-bounding faults are discontinuous south of the Three Sisters area, with faulting only occurring along 45 percent of the High Cascades-Western Cascades transition between latitudes $43^{\circ}-44^{\circ} \mathrm{N}$ (Sherrod, 1986). Thus, a throughgoing graben did not develop south of the Three Sisters area (Sherrod, 1986; Sherrod and Smith, 1989). East of the High Cascades axis, at least $700 \mathrm{~m}$ of vertical displacement is present along Green Ridge (Hales, 1974; Conrey, 1985; Wendland, 1988). Based on gravity data, low density volcanic or volcaniclastic rocks underlie the area between Green Ridge and the High Cascades volcanic axis (Couch and others, 1982). Stratigraphic relationships constrained from nearby drill cores (Figure 2-2) require more than $1 \mathrm{~km}$ of vertical displacement at the eastern boundary of the graben (Priest and others, 1989; Priest, 1990; this study). However, it is unclear if north-striking graben

faults extend directly south of Green Ridge and are buried by younger units (Conrey, 1985; Smith, 1986b; Livelybrooks and others, 1989; Taylor, 1990; Hill, 1991), or if graben-bounding faults merge with the Tumalo Fault Zone and distribute displacement over a 60-km-wide fault zone (Peterson and others, 1976; Lawrence, 1976; MacLeod and Sherrod, 1988; Smith and others, 1987).

In addition to graben formation about $5.4 \mathrm{Ma}$, the Western Cascades underwent a period of uplift commencing about 5 Ma (Priest and others, 1983; Sherrod, 1986; Priest, 1990). Uplift resulted in entrenchment of streams in the Western Cascades, and volcanic rocks younger than $4.5 \mathrm{Ma}$ in the Western Cascades subprovince generally form intra- 
canyon flows (Priest, 1990). West of the High Cascades, 7-5-Ma volcanic rocks (Figure 2-2) occur at nearly constant elevations, indicating that uplift was relatively uniform. However, early High Cascades rocks on the east side of the High Cascades apparently were not uplifted (Taylor, 1981); mafic lavas at Green Ridge have shallow eastward dips consistent with an original depwsitional slope, and the decrease in dip from Green Ridge to the east is consistent with observed proximal to distal fincies changes in the Deschutes Formation (Conrey, 1985; Smith, 1986b).

\section{Late High Cascades}

Late High Cascades volcanism encompasses rocks that were erupted after the formation of the graben about $5 \mathrm{Ma}$, although only a small amount of 5-2-Ma units are exposed; the bulk of the 5-2-Ma late High Cascades rocks presumedly fills the early High Cascades grabsa. Small outcrops of approximately 4.3 Ma graben-filling lavas are exposed at the north end of Green Ridge (Yogodzinski, 1985). Diatomaceous sedimentary rocks, palagonitic tuffs, and mafic lava are exposed near the western boundary of Green Ridge (Smith, 1986b) and from about $250 \mathrm{~m}$ to $600 \mathrm{~m}$ in the Unocal $82-3$ drill core (Figure 2-2; G. Black, written commun., 1988). Diatoms from the lower $100 \mathrm{~m}$ of the $82-3$ drill core consist of an early Pleistocene-late Pliocene assemblage (P. Bradbury, written commun., 1989), and a basalt flow within this interval has a KAr age of $1.49 \pm 0.06 \mathrm{Ma}$ (Priest and others, 1989). Diatomaceous sedimentary rocks, palagonitic tuff and pillowed lava are well exposed west of Santiam Pass in the approximately 1.8-Ma Parkette Creek unit of Black and others (1987). About 30 km southwest of Santiam Pass, 3.6-2.2-Ma basalt, basaltic andesite, and andesite lavas appear to fill the High Cascades graben (Priest and others, 1988). In addition, approximately 4 Ma mafic flows constitute most of Woodpecker Ridge (Conrey, 1991) southwest of Mt. Jefferson (Figure 2-2), and the 2-3-Mat Mt. Bruno basalt flows of Priest and others (1987b) define the base of the late High Cascades section near Minto Mtn.

Most rocks from the late High Cascades eruptive episode consist of mafic flows younger than about $2 \mathrm{Ma}$. In much of the central Oregon Cascades, including the Santiam Pass area, rocks younger than 0.79 Ma (Brunhes NormalPolarity Chron; Johnson, 1982) cover much of the area for $=20 \mathrm{~km}$ east and west of the High Cascades axis (Figure 2-2). Late High Cascades vents between $2 \mathrm{Ma}$ and $0.79 \mathrm{Ma}$ are usually exposed only more than $20 \mathrm{~km}$ away from the present volcanic axis. Examples of approximately 2-Ma mafic composite volcanoes include Bald Peter (2.1 $\pm 0.2 \mathrm{Ma}$, Armstrong and

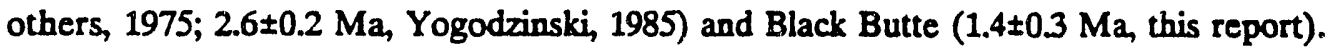

In the area between Mount Jefferson and the Three Sisters, late Hligh Cascades shield volcanoes and mafic flows are the dominant rock type (McBirney and others, 1974) and have coalesced to form a broad mafic platform (Hughes and Taylor, 1986). Mafic platform flows are predominantly diktytaxitic, high-alumina basalt and basaltic andesite (Hughes and Taylor, 1986). Three Fingered Jack (Figure 2-2) and Mount Washington are two examples of highly-eroded mafic shield volcanoes that overlie the mafic platform. Andesite (58-63 percent $\mathrm{SiO}_{2}$ ) is restricted to small domes along the High Cascades axis (Figure 2-2) and to larger composite volcanoes such as Mourat Jefferson and Middle Sister. Rocks more silicic than andesite only occur at or adjacent to large, long-lived composite volcanoes.

The youngest volcanic units in the Santiam Pass area are associated with the Holocene Sand Mountain cinder cones (Figure 2-2). Carbonized wood from beneath these mafic flows has a ${ }^{14} \mathrm{C}$ age of 3,900 \pm 200 years B.P. (Taylor, 1965, 1967). Sand Mountain flows produced snall lakes by damming the McKenzie River; submerged trees in these lakes have ${ }^{14} \mathrm{C}$ ages 


\section{Hill and Priest}

of about 3,000 years B.P. (Benson, 1965). In addition, the explosive eruption of Blue Lake crater $10 \mathrm{~km}$ east of the Santiam Pass drill site occurred 3,500 \pm 250 years B.P. (Taylor, 1967).

\section{INEW RADIOMETRIC AGES}

In 1982, Unocal Geothermal drilled a 500-m-deep core hole $36 \mathrm{~km}$ north-northwest of the Santiam Pass well at an elevation of $885 \mathrm{~m}$ in the valley of Marion Creek (Figure 2-2, site Unocal 82-1). Upper Miocene to lower Pliocene volcanic rocks in the Minto Mountain-Marion Creek area (Black and others, 1987; Conrey, 1991) occur 10-20 km east of the presumed western boundary of the High Cascades graben. Faults along the eastern boundary of the graben at Green Ridge (Figure 2-2) apparently do not continue north of the latitude of the Minto Mountain area (Conrey, 1985;

Yogodzinski, 1985; Wendland, 1988). Upper Miocene volcanic rocks that crop out in Marion Creek were thought to correlate (unit Tma of Black and others, 1987 and Priest and others, 1987b) with 10-11 Ma andesite located $23 \mathrm{~km}$ northwest of Mount Jefferson (White, 1980). However, isotopic age data from the Unocal drill core and Conrey (1991) suggest that these rocks are much younger.

The apparent contact between Quaternary High Cascades mafic flows and older volcanic rocks occurs at a depth of $407 \mathrm{~m}$ in the Unocal 82-1 core (G. Black, written commun., 1990). The older rocks from $407 \mathrm{~m}$ to $500 \mathrm{~m}$ consist primarily of altered, 2-pyroxene andesite lavas with interbedded volcaniclastic rocks (G. Black, written commun., 1990). In order to bettex constrain structural and geological models for the central Cascades, a whole-rock ${ }^{40} \mathrm{Ar} /{ }^{9} \mathrm{Ar}$ age was obtained from a relatively fresh rhyodacite (Sample U-1575, Table 3-2) flow at a depth of $480 \mathrm{~m}$ in the Unocal 82-1 core. This unit has a well-constrained plateau age of 5.62 $\pm 0.09 \mathrm{Ma}$ (Figure 2-3). Silicic rocks of similar age (about $4 \mathrm{Ma}$ ) are also exposed 3-11 km north of Unocal 82-1 at Minto Mountain and Woodpecker Hill (Conrey, 1991).
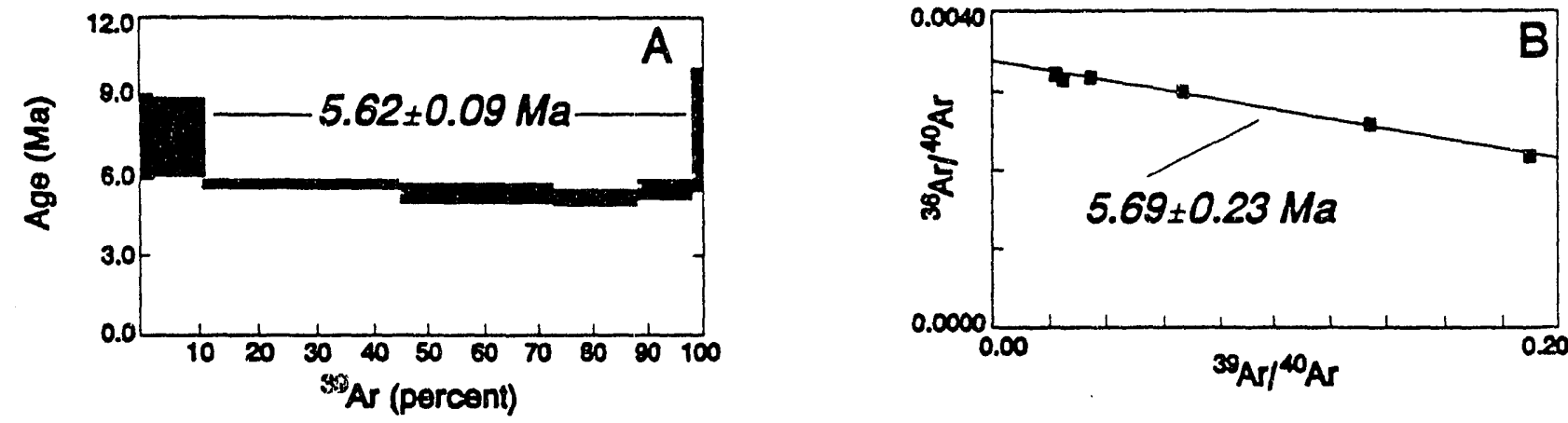

Figure 2-3. Calculated whole-rock ${ }^{\circ} \mathrm{Ar} / \mathrm{As}$ Ar dates for a thyodacite flow from a depth of $480 \mathrm{~m}$ in the Unocal 82-1 well. (A) Dates calculated for $<10 \%$ and $>98 \%{ }^{39}$ Ar release are anomalously old with relatively large uncertainties, which is typical for weakty altered volcanic rocks ( $R$. Duncan, oral commun., 1991). Note that the plateau ages for $>10 \%$ and $<98 \%{ }^{30}$ Ar release have low uncertainty and give a platean age of $5.62 \pm 0.09 \mathrm{Ma}$. (B) Regression of the first 6 analyses gives an age of $5.69 \pm 0.23 \mathrm{Ma}$, which is within the range of 10 error for the plateau age.

West and northwest of Minto Mountain, $6.3 \mathrm{Ma}$ volcanic rocks occur at elevations as much as $700 \mathrm{~m}$ higher than the 5.6-4 Ma flows in the Minto Mountain area, suggesting that part of the western boundary of the High Cascades graben is located in that area. The distribution of early High Cascades units in the Minto Mountain area may also indicate that the western boundary of the graben steps about $10 \mathrm{~km}$ east in the Minto Mountain-Mt. Jefferson area. However, the lack 


\section{Geologic setting of the Santiam Pass area}

of significant faulting at the northern terminus of Green Ridge clearly shows that the eastern boundary of the High Cascades graben did not extend north of latitude $44^{\circ} 45^{\prime}$ (Figure 2-2).

The location of the western boundary of the High Cascades graben immediately west of the Santiam Pass well is not clear. The EWEB 78-32 well (Plate 1) encountered Pliocene to Miocene lavas at a depth of only about $300 \mathrm{~m}$ (Black and others, 1987). The occurrence of Pliocene to Miocene lavas at this shallow depth indicates that the western boundary of the graben must be located east of the EWEB 78-32 well. The promiment northward alignment of the Sand Mountain cinder cones (Plate 1) is probably controlled by a buried fault, which may mark the western boundary of the graben. Displacements along this postulated fault are limited by the age-depth relationships shown in Plate 1 for the Santiam Pass, EWEB 78-32 and Unocal 82-3 wells. These subsurface relationships suggest that the graben is asymmetrical in this area and probably has increasing displacement to the south and east through south-eastward dip or by distributed faulting. This model also accounts for the $2-3 \mathrm{~km}$ of graben fill shown on the eastern part of the cross section in Plate 1 .

Several small andesitic domes (Davie, 1980; Taylor, 1981) were erupted at Hogg Rock and Hayrick Butte about 4 $\mathrm{km}$ west and $6 \mathrm{~km}$ southwest of the well site respectively (Figure 2-2). These andesite domes have steep sides with glassy margins and subhorizontal columns, relatively flat tops, and are anomalously thick, all of which are features generally ascribed to subglacial eruptions (Williams and McBirney, p. 199, 1979; Conrey, 1991). The tops of these andiesitic units have been extensively eroded by glaciation, and it is possible that Hogg Rock and Hayrick Butte are subaerial andesite domes that have been extensively glar iz..d (E.M. Taylor, oral commun., 1992). Hogg Rock and Hayrick Butce have normal magnetic polarities (E. M. Taylui, oral commun., 1990). A K-Ar age of 0.09 \pm 0.02 Ma obtained for Hogg Rock is consistent with eruption during or immediately after early Wisconsin glaciation at about $0.11 \mathrm{Ma}$ (Jouzel and others, 1987). Subglacial andesitic domes of $0.09 \pm 0.04 \mathrm{Ma}$ are also exposed $23 \mathrm{~km}$ north-northeaset of the drill site at The Table (Conrey, 1991). The andesitic domes of The Table are slightly more mafic than Hogg Rock and Hayrick Butte (Table 2-2), but all these andesite domes have incompatible element abundances that are much lower than other andesitic rocks in the area (Conrey, 1991, oral commun., 1990; Hughes, 1983; this study).

TABLE 2-1: New whole rock $K$-Ar ages for surface samples from the Süntiam Pass area.

Sample Sample $K \quad{ }^{40} \mathrm{Ar}_{\text {rod }}{ }^{40} \mathrm{Ar}_{\text {rod }} \mathrm{Age}(\mathrm{Ma})$ Comments

no. $\quad w t(g) \quad(w t \%) \times 10^{-12} \mathrm{~mol} / \mathrm{g}(\%) \quad( \pm 10)$

\begin{tabular}{lclllll}
\hline TFJ-2 & 5.01 & 0.75 & 0.11 & 2.1 & $0.09 \pm 0.02$ & Hogg Rock, black glassy margin of fiow \\
811108 & 15.64 & 0.668 & 0.834 & 4.1 & $0.72 \pm 0.19$ & Reversed basalt, Hwy. 20, 0.5 km N. of Blue Lake \\
8111110 & 15.84 & 0.193 & 0.478 & 8.6 & $1.42 \pm 0.33$ & Reversed basalt, 1 km E. of Black Butte summit
\end{tabular}

Notes:

- Sample TFJ-2: Potassium (K) determined by atomic absorption spectrometry at the University of Oregon by $\mathrm{C}$. McBirney. Isotopic ratios determined at Oregon State University by R. Duncan.

- Samples 811108 \& 811110: All analyses by B. Dalrymple, U.S. Geological Survey, unpublished research, 1981. Potassium $(K)$ is the average of 4 analyses $(10=1 \%)$.

- Decay constants: $\lambda_{\mathrm{g}}=0.581 \times 10^{-10} \mathrm{yr}^{-1}, \lambda_{\mathrm{B}}=4.962 \times 10^{-10} \mathrm{yr}^{-1}$, and ${ }^{40} \mathrm{~K} / \mathrm{K}_{\text {low }}=1.167 \times 10^{-4} \mathrm{~mol} / \mathrm{mol}$ (Steiger and Jãger, 1977). 
Table 2-2. Analyses of Hogg Rock-type andesites in the Santiam Pass-Mount Jefferson area, and a representative late High Cascades basaltic andesite from near the Santiam Pass 77-24 well.

\begin{tabular}{|c|c|c|c|c|c|c|}
\hline $\mathrm{SiO}_{2}$ & 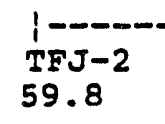 & $\begin{array}{l}\text { Hogg Rock } \\
\text { TFJ-433 } \\
59.7\end{array}$ & $\begin{array}{l}\text { RCMJ }-58 \\
59.8\end{array}$ & $\begin{array}{l}\text { Hayrick } \\
\text { RCNSH-4 } \\
60.1\end{array}$ & $\begin{array}{l}\text { Table } \\
\text { RCMJ-524 } \\
57.8\end{array}$ & $\begin{array}{l}\text { QTba } \\
83190 \\
56.1\end{array}$ \\
\hline & 0.68 & 0.7 & 0.68 & 0.68 & 0.96 & 0.83 \\
\hline & 18.5 & 18.4 & 18.4 & 18.4 & 18.6 & 19.0 \\
\hline & 5.69 & 5.7 & 5.68 & 5.55 & 6.86 & 6.31 \\
\hline Mno & 0.11 & - & 0.11 & 0.11 & 0.10 & 0.11 \\
\hline Mgo & 3.43 & 3.8 & 3.56 & 3.30 & 3.58 & 4.81 \\
\hline CaO & 6.42 & 6.3 & 6.49 & 6.24 & 7.10 & 8.08 \\
\hline $\mathrm{Na}_{2} \mathrm{O}$ & 4.33 & 4.10 & 4.20 & 4.42 & 3.88 & 4.02 \\
\hline $\mathrm{K}_{2} \mathrm{O}$ & 0.97 & 1.05 & 0.97 & 1.08 & 0.92 & 0.67 \\
\hline $\mathrm{P}_{2} \mathrm{O}_{5}$ & 0.11 & - & 0.11 & 0.12 & 0.21 & 0.15 \\
\hline TOTAL & 101.30 & 99.75 & $n / r$ & $n / x$ & $n / r$ & 99.59 \\
\hline $\begin{array}{l}R b \\
C s \\
S r \\
B a\end{array}$ & $\begin{array}{l}12 \\
0.35 \\
541 \\
259\end{array}$ & $\begin{array}{l}15 \\
0.29 \\
640 \\
260\end{array}$ & $\begin{array}{r}13 \\
550 \\
248\end{array}$ & $\begin{array}{c}14 \\
0.34 \\
515 \\
297\end{array}$ & $\begin{array}{r}12 \\
741 \\
346\end{array}$ & $\begin{array}{r}8 \\
- \\
613 \\
178\end{array}$ \\
\hline $\begin{array}{l}\mathrm{SC} \\
V \\
\mathrm{Ni} \\
\mathrm{Cr} \\
\mathrm{CO} \\
\mathrm{ZI} \\
\mathrm{Ga}\end{array}$ & $\begin{array}{l}14.3 \\
113 \\
30 \\
37 \\
20.3 \\
63 \\
20\end{array}$ & $\begin{array}{l}13.9 \\
- \\
35 \\
39 \\
20.3 \\
= \\
=\end{array}$ & $\begin{array}{l}21 \\
96 \\
38 \\
34 \\
- \\
69 \\
15\end{array}$ & $\begin{array}{r}13 \\
106 \\
34 \\
26 \\
- \\
61 \\
17\end{array}$ & $\begin{array}{r}18 \\
163 \\
92 \\
25 \\
- \\
79 \\
20\end{array}$ & $\begin{array}{r}17 \\
130 \\
74 \\
33 \\
- \\
62 \\
19\end{array}$ \\
\hline $\begin{array}{l}\text { La } \\
\mathrm{Ce} \\
\text { Nd } \\
\text { Sm } \\
\text { Eu } \\
\text { Tb } \\
\text { Yb } \\
\text { Lu } \\
\text { Eu/Eu* }\end{array}$ & $\begin{array}{c}9 \\
16.2 \\
9.2 \\
2.18 \\
0.84 \\
0.39 \\
1.3 \\
0.15 \\
1.12\end{array}$ & $\begin{array}{c}8.2 \\
18.7 \\
2 \\
2.36 \\
0.87 \\
0.27 \\
1.1 \\
0.16 \\
1.19\end{array}$ & $\begin{array}{l}- \\
\overline{-} \\
- \\
- \\
- \\
-\end{array}$ & $\begin{array}{r}9.48 \\
18.63 \\
9.68 \\
2.42 \\
0.93 \\
0.39 \\
1.18 \\
0.19 \\
1.15\end{array}$ & $\begin{array}{l}- \\
- \\
- \\
- \\
- \\
- \\
-\end{array}$ & $\begin{array}{l}- \\
\overline{-} \\
\overline{-} \\
\overline{-} \\
\overline{-} \\
-\end{array}$ \\
\hline $\begin{array}{l}Y \\
Z r \\
H f \\
\text { Nb } \\
\text { Ta } \\
T h \\
U\end{array}$ & $\begin{array}{r}12 \\
102 \\
2.2 \\
3.4 \\
0.2 \\
1.3 \\
<5\end{array}$ & $\begin{array}{c}100 \\
2.5 \\
- \\
0.25 \\
1.1 \\
0.1\end{array}$ & $\begin{array}{c}11 \\
100 \\
- \\
4.6 \\
- \\
- \\
-\end{array}$ & $\begin{array}{l}12.4 \\
97 \\
2.17 \\
4.52 \\
- \\
1.28 \\
0.37\end{array}$ & $\begin{array}{r}16 \\
126 \\
- \\
6 \\
- \\
- \\
-\end{array}$ & $\begin{array}{l}9 \overline{3} \\
\overline{5} .9 \\
\overline{-} \\
-\end{array}$ \\
\hline
\end{tabular}

n/r: not Reported -: not analyzed

TFJ-2: From east glassy margin of Hogg Rock, K-Ar sample, this study.

TFJ-433: Glassy margin of Hogg Rock, from Hughes (1983).

RCHJ-58: Glassy margin of Hogg Rock, R. Conrey, unpub. data, 1991.

RCNSH-4: Margin of Hayrick Bu., R. Conrey, unpub. data, 1991.

RCMJ-524: Margin of Middle Tabie, S. Mount Jefferson (Conrey, 1991).

83190: Basaltic andesite lava in roadcut, U.S. Hwy. 20, 4 km east of Santiam Pass Well 77-24. Possesses reversed-polarity magnetization. 
The age of Black Butte was reported to be $0.45 \pm 0.3 \mathrm{Ma}$ by Armstrong and others, (1975), although Black Butte lavas have reversed paleomagnetic directions. A more recent $\mathrm{K}$-Ar analysis of a basaltic andesite flow $1 \mathrm{~km}$ east of the Black Butte summit gives an age of $1.42 \pm 0.33 \mathrm{Ma}$ (Tabli 2-1). This age is consistent with eruption during the Matuyama Reversed-Polarity Chron (Mankinen and Dalrymple, 1979).

Mafic flows with reversed magnetic directions are well exposed along U.S. Highway 20 from 5 to $15 \mathrm{~km}$ east of the Santiam Pass drill site (Figure 2-2). A magnetically reversed basaltic andesite flow about $1 \mathrm{~km}$ north of Blue Lake (Plate 1) has yielded a K-Ar age of $0.54 \pm 0.14 \mathrm{Ma}$ (Armstrong and others, 1975). Reanalysis of this unit gives a K-Ar age of $0.72 \pm 0.19 \mathrm{Ma}$ (Table 2-1), which also is consistent with eruption during the Matuyama Reversed-Polarity Chron (Mankinen and Dalrymple, 1979).

\section{GEOLOGIC MAP AND CROSS SECTION}

The 1:62,500-scale geologic map and cross section (Plate 1) was initially compiled by D.R. Sherrod as part of a preliminary geologic study of the Santiam Pass area (Priest and others, 1987a). Subsequent modifications to the map are minor; magnetically reversed rocks are grouped into the QTba units, and additional rock ages and well sites are added to the map. The cross section was modified to include subsurface data from the Santiam Pass 77-24, Unocal 82-3, and Unocal 82-1 wells located ir Figure 2-2.

Drilling at Santiam Pass has shown that the boundary between normal and reversely polarized ( $0.79 \mathrm{Ma}$, Johnson, 1982) High Cascades lavas occurs at a depth of $165 \mathrm{~m}$. However, 1.8-Ma mafic rocks are located $920 \mathrm{~m}$ depth (Chapter 3), which is deeper than expected based on the preliminary cross section (Priest and others, 1987a). Additional constraints on the thickness and extent of $\approx 1-2 \mathrm{Ma}$ units can be obtained from the Unocal 82-3 well. In Unocal 82-3 (Figure 2-2), reversed-polarity flows first occur at a depth of $238 \mathrm{~m}$. Although core recovery in Unocal 82-3 is intermittent between 238 $\mathrm{m}$ and $378 \mathrm{~m}$, all of the flows in the recovered core have reversed polarities. A magnetically reversed diktytaxitic basalt flow at $378 \mathrm{~m}$ in Unc:al 82-3 has a K-Ar age of 1.35 $\pm 0.07 \mathrm{Ma}$ (Priest and others, 1989), which is consistent with eruption during the Matuyama Reversed-Polarity Chron (Mankinen and Dalrymple, 1979). Reversed-polarity flows continue from $373 \mathrm{~m}$ to $460 \mathrm{~m}$, with complete core recovery in that interval. From $460 \mathrm{~m}$ to the base of the well at $600 \mathrm{~m}$, core recovery is very sporadic. This interval consists primarily of diatomaceous and tuffaceous sedimentary rocks along with interbedded mafic flows, peperite, and palagonitic tuff. A basalt flow at $531 \mathrm{~m}$ has a K-Ar age of $1.49 \pm 0.06 \mathrm{Ma}$ and is underlain by reversed-polarity mafic flows. The age of the $1.49-\mathrm{Ma}$ flow is also consistent with eruption during the Matuyama Reversed-Polarity Chron.

Projection of the Unocal 82-3 well onto the Santiam Pass cross section (Plate 1) is justified because the perpendicular projection of the well site onto the cross section occurs along a line of nearly constant elevation, and the projected Brunhes-Matuyama boundary in Unocal 82-3 is consistent with the observed elevation of this contact along the cross section line. The abundance of diatomaceous and tuffaceous mudstone and siltstone in well 82-3, along with the numerous features indicating lava-wet sediment interaction, shows that deposition occurred in a low-energy (closed?) basin adjacent to active mafic volcanoes. Projection of these data onto the Santiam Pass cross section (Plate 1) constrains an expected facies change from lava flow-dominated medial facies on the volcanic axis (Santiam Pass $77-24$ ) to a distal facies 


\section{Hill and Priest}

with significant sedimentary component (Unocal 82-3). These relationships indicate that 1.8-1.4-Ma volcanism in the Santiam Pass area probably occurred within a topographic low, i.e., the High Cascades graben.

Similar facies relationships are observed west of the Santiam Pass well. Tuffaceous and diatomaceous sedimentary rocks of Parkette Creek (Black and others, 1987) contain interbedded mafic flows that have K-Ar ages of about $1.8 \mathrm{Ma}$. The facies assemblage of the Parkette Creek units is nearly identical to the assemblage found in the lower $250 \mathrm{~m}$ of the Unocal 82-3 core, and from about $150 \mathrm{~m}$ to about $400 \mathrm{~m}$ in the Unocal 82-1 core (G. Black, written commun., 1988). The Parkette Creek unit most likely represents the western facies of the graben-filling rocks and has a minimum thickness of $450 \mathrm{~m}$ (Black and others, 1987), although the base of the unit is not exposed. It is also unlikely that the thickness of the Parkette Creek unit is much greater than $500 \mathrm{~m}$ on the basis of the stratigraphic relationships shown in Plate 1.

Well data can be used to estimate a minimum thickness of the graben-filling strata in the Green Ridge area. The I $\mathrm{D}$ of the Deschutes Formation is first assumed to occur close to the base of Santiam Pass 77-24. Mafic flows of the Deschutes Formation were presumedly deposited on a slope that dipped at least as much as observed at Green Ridge $\left(5^{\circ}\right.$, Conrey, 1985), and that the minimum thickness of these flows is exposed at Gree:n Ridge ( $\geq 700 \mathrm{~m}$, Conrey, 1985). These constraints result in a thickness of roughly $2 \mathrm{~km}$ for the graben fill near Green Ridge (Plate 1).

The thickness of the graben-filling strata west of the Santiam Pass well is probably much less than in the Green Ridge area (Plate 1), although this relationship is less constrained. EWEB 78-32 reached mafic flows correlative with the Deschutes Formation at about $300 \mathrm{~m}$ (Black and others, 1987), suggesting that $150 \mathrm{~m}$ of Parkette Creek may have eroded from this area. If large faults occur on the western boundary of the graben at this latitude, then they must occur east of the EWEB 78-32 well in order to account for the shallow depth to Deschutes-correlative flows. These buried faults may control the alignment of the Holocene Sand Mountain cinder cones (Plate 1 and Figure 2-2) in the same manner that: Green Ridge faults apparently control the alignment of Quaternary cinder cones near Wizard Falls and Garrison Buttes (Conrey, 1985).

\section{GEOLOGIC SUMMARY AND CONCLUSIONS}

The Santiam Pass area of the Oregon High Cascades is located on the axis of an active continental volcanic arc. Most of the volcanic eruptions within the last $0.79 \mathrm{Ma}$ have been mafic $\left(\mathrm{SiO}_{2}<58 \%\right)$, although isolated andesitic eruptions also have occurred in this area since $0.1 \mathrm{Ma}$. The major structural features are north- to northwest-striking normal faults, which are associated with the formation of a discontinuous, asymmetrical intra-arc graben about $5 \mathrm{Ma}$. A minimum of 2 $\mathrm{km}$ vertical displacement is associated with the graben in the Green Ridge area east of the Santiam Pass. Grabenbounding faults are not exposed more than $40 \mathrm{~km}$ northeast or northwest of the Santiam Pass. The presence of late Pleistocene to Holocene volcanism in an area of abundant faulting and groundwater recharge may create a significant geothermal resource.

Although the surficial geology of this area has been well studied, there is a paucity of subsurface data to constrain many basic geological, geophysical and geothermal models. Previous deep ( $>150 \mathrm{~m}$ ) drilling programs have focused on the Western Cascades (Sherrod, 1988) or known thermal features in the Western Cascades (White, 1980), or on major stratovolcanic systems in the High Cascades (Priest and Vogt, 1982). These data are inappropriate to constrain geological 
models for most of the High Cascades arc. Additional data from deep drilling programs were necessary to adequately evaluate the thermal regime and geologic history of the Oregon Cascades. The Santiam Pass drilling program was thus formulated to provide these data (Priest and others, 1987a).

\section{ACKNOWLEDGMENTS}

Gerald Black, DOGAMI, provided detailed lithology logs and many useful interpretations of the Unocal 82-1 and 82-3 drill cores. We thank Brent Dalrymple and Duane Champiun for providing their previously unpublished K-Ar analyses and paleomagnetic data for Black Butte and contemporaneous lavas along Highway 20. This chapter has been improved through numerous discussions with Edward Taylor, Richard Conrey, Gerald Black, and David Sherrod, and through thoughtful reviews by Taylor, Sherrod, and Beverly Vogt.

\section{REFERENCES CITED}

Allen, J.E., 1966, The Cascade Range volcano-tectonic depression of Oregon, in Staples, L.W., Green, J., eds., Lunar Geological Field Conference Transactions: Oregon Department of Geology and Mineral Industries, p. 21-23.

Armstrong, R.L., Taylor, E.M., Hales, P.O., and Parker, DJ., 1975, K-Ar dates for volcanic rocks, central Cascade Range of Oregon: Isochron/West, no. 13, p. 5-7.

Benson, G.T., 1965, The age of Clear Lake, Oregon: Ore Bin, v. 27, p. 37-40.

Black, G.L., Woller, N.M., and Ferns, M.L., 1987, Geologic map of the Crescent Mountain area, Linn County, Oregon, scale 1:62500: Oregon Department of Geology and Mineral Industries Map GMS-47.

Callaghan, E., 1933, Some features of the volcanic sequence in the Cascade Range in Oregon, American Geophysical Union Transactions, 14th Annual Meeting, p. 243-249.

Conrey, R.M., 1985, Volcanic stratigraphy of the Deschutes Formation, Green Ridge to Fly Creek, no th-central Oregon: Corvallis, Oreg., Oregon State University, M.S. thesis, 349 p.

-1991, Geology and petrology of the Mount Jefferson area, High Cascades Range, Oregon: Pullman, Wash., Washington State University, Ph.D. dissertation, $357 \mathrm{p}$.

Couch, R.W., Pitts, G.S., Gemperle, M., Braman, D.E., and Veen, C.A., 1982, Gravity anomalies in the Cascade Range in Oregon: Structural and thermal implications: Oregon Department of Geology and Mineral Industries Open-File Report 0-82-9.

Cummings, M.L., Pollock, J.M., Thompson, G.D., and Bull, M.K., 1990, Stratigraphic development and hydrothermal activity in the central Western Cascade Range, Oregon: Journal of Geophysical Research, v. 95, p. 19601-19610.

Davie, E.I., 1980, The geology and petrology of Three Fingered Jack, a High Cascades volcano in central Oregon: Eugene, Oreg., University of Oregon, M.S. thesis, 138 p.

Hales, P.O., 1974, Geology of the Green Ridge area, Whitewater River quadrangle, Oregon: Corvallis, Oreg., Oregon State University, M.S. thesis, 90 p. 
Hayman, G.A., 1983, Geology of a part of the Eagle Butte and Gateway quadrangles, east of the Deschutes River, Jefferson County, Oregon: Corvallis, Oreg., Oregon State University, M.S. thesis, 97 p.

Hill, B.E., 1991, Petrogenesis of compositionally distinct silicic volcanoes in the Three Sisters region of the Oregon Cascade Range: The effects of crustal extension on the development of continental arc silicic magmatism: Corvallis, Oreg., Oregon State University, Ph.D. dissertation, 235 p.

Hughes, S.S., 1983, Petrenemical evolution of the High Cascades volcanic rocks in the Three Sisters region, Oregon: Corvallis, Oreg., Oregon State. University, Ph.D. dissertation, 199p.

Hughes, S.S., and Taylor, E.M., 1986, Geochemistry, petrology and tectonic implications of central High Cascades mafic platform lavas: Geological Society of America Bulletin, v. 97, p. 1024-1036.

Johnson, R.G., 1982, Brunhes-Matuyama magnetic reversal dated at 790,010 yr B.P. by marine-astronomical correlations: Quaternary Research, v. 17, p. 135-147.

Jouzel, J., Lorius, C., Petit, J.R., Genthon, C., Barkov, N.I., Kotlyakov, V.M., and Petrov, V.M., 1987, Vostok ice core: A continuous isotope temperature record over the last climatic cycle (160,000 years): Nature, v. 329, p. 403-408.

Keach, W.R., Oliver, J.E., Brown, L.D., and Kaufman, S., 1989, Cenozoic active margin and shallow Cascades structure: COCORP resuits from western Oregon: Geological Society of America Bulletin, v. 101, p. 783-794.

Keith, T.E.C., 1988, Regional patterns of hydrothermal alteration in the Breitenbush-Austin Hot Springs area of the Cascade Range, Oregon, in Sherrod, D.R., ed., Geology and geothermal resources of the Breitenbush-Austin Hot isprings area, Clackamas and Marion Counties, Oregon: Oregon Department of Geology and Mineral Industries Open-File Report 0-88-5, p. 31-45.

Lawrence, R.D., 1976, Strike-slip faulting terminates the Basin and Range province in Oregon: Geological Society of America Bulletin, v. 87, p. 846-85C.

Livelybrooks, D.W., Clingman, W.W., Rygh, J.T., Urquhart, S.A., and Waff, H.S., 1989, A magnetotelluric study of the High Cascade graben in central Oregon: Journal of Geophysical Research, v. 94, p. 14173-14184.

MacLeod, N.S., and Sherrod, D. R., 1988, Geologic evidence for a magma chamber beneath Newberry Volcano, Oregon: Journal of Geophysical Research, 93-B9, p. 10067-10079.

Mankinen, E.A., and Dalrymple, G.B., 1979, Revised geomagnetic polarity time scale for the interval 0-5 m.y. B.P.: Journal of Geophysical Research, v. 84, p. 615-626.

McBirney, A.R., Sutter, J.F., Naslund, H.R., Sutton, K.G., and White, C.M., 1974, Episodic volcanism in the central Oregon Cascade Range: Geology, v. 2, p. 585-589.

Peck, D.L., Griggs, A.B., Schlicker, H.G., Wells, F.G., and Dole, H.M., 1964, Geology of the central and northern parts of the Western Cascade Range in Oregon: U.S. Geological Survey Professional Paper 449, 56p.

Peterson, N.V., Groh, E.A., Taylor, E.M., and Stensland, D.E., 1976, Geology and mineral resources of Deschutes County, Oregon: Oregon Department of Geology and Mineral Industries Bulletin 89, 66 p.

Power, S.G., 1984, The "tops" of prophyry copper deposits - Mineralization and plutonism in the Western Cascades, Oregon: Corvallis, Oreg., Oregon State University, Ph.D. dissertation, 234 p.

Priest, G.R., 1990, Volcanic and tectonic evolution of the Cascade volcanic arc, central Oregon: Journal of Geophysical Research, v. 92 , p. $19583-19599$. 
Priest, G.R., Bargar, KE., Black, G.R., Blackwell, D.D., Couch, R.A., Duncan, R.A., Evans, J., Goldstein, N., Haimson, B.C., Hugh 's, S., Iyer, M., Keith, T.E.C., Korosec, M.A., Laul, J.C., Levy, S., Mariner, R.H., Mooney, W.D., Rowley, J., Sherrod, D.R., Smith, M., Waibeh A., Weaver, C.S., Woller, N.M., and Wright, P.M., 1987a, Investigation of the thermal regime and geologic history of the Cascade volcanic arc: First phase of a program for scientific drilling in the Cascade Range: Oregon Department of Geology and Mineral Industries Open-File report 0-86-3, $120 \mathrm{p}$.

Priest, G.R., Black, G.L., Woller, N.M., and Taylor, E.M., 1988, Geologic map of the McKenzie Bridge quadrangle, Lane County, Oregon, scale 1:62500: Oregon Department of Geology and Mineral Industries Map GMS-48.

Priest, G.R., Mattinson, J.M., and Damon, P.E., 1989, Implications of new isotopic age data from drill holes in the Oregon Cascades [abs.]: EOS, v. 71, p. 1299.

Priest, G.R., and Vogt, B.A., 1982, Geology and geothermal resources of the Mount Hood area, Oregon: Oregon Department of Geology and Mineral Industries Special Paper 14, 100 p.

Priest, G.R., V/oller, N.M, Black, G.L., and Evans, S.H., 1983, Overview of the geology of the central Oregon Cascade Range: in Priest, G.R., Vogt, B.F., eus., Geology and geothermal resources of the central Oregon Cascade Range, Oregon Department of Geology and Mineral Industries Special Paper 15, 123 p.

Priest, G.R., Woller, N.M, and Ferns, M.L., 1987b, Geologic map of the Breitenbush River area, Linn and Marion Counties, Oregon, scale 1:62500: Oregon Department of Geology and Mineral Industries Map GMS-46.

Sherrod, D.R., 1986, Geology, petrology, and volcanic history of a portion of the Cascade Range between latitudes $43^{\circ}$. $44^{\circ}$ N, central Oregon, U.S.A.: Santa Barbara, Calif., University of California, Ph.D. dissertation, 320 p.

-1988, Geology and geothermal resources of the Breitenbush-Austin Hot Springs area, Clackamas and Marion Counties, Oregon: Oregon Department of Geology and Mineral Industries Open-File Report 0-88-5, 91 p.

Sherrod, D.R., and Conrey, R.M., 1988, Geologic setting of the Breitenbush-Austin Hot Springs area, Cascade Range, north-central Oregon, in Sherrod, D.R., ed., Geology and geothermal resources of the Breitenbush-Austin Hot Springs area, Clackamas and Marion Counties, Oregon: Oregon Department of Geology and Mineral Industries Open-File Report 0-88-5, p. 1-14.

Sherrod, D.R., and Smith, J.G., 1989, Preliminary map of upper Eocene to Holocene volcanic and related rocks of the Cascade Range, Oregon: U.S. Geological Survey Open-File Report 89-14, 20 p.

Smith, G.A., 1986a, Simtustus Formation: Paleogeographic and stratigraphic significance of a newly defined Miocene unit in the Deschutes Basin, central Oregon: Oregon Geology, v. 48, p. 63-72.

-1986b, Stratigraphy, sedimentology and petrology of Neogene rocks in the Deschutes Basin, central Oregon: A record of continental-margin volcanism and its influence on fluvial sedimentation in an arc-adjacent basin: Corvallis, Oreg., Oregon State University, Ph.D. dissertation, 467 p.

Smith, G.A., Snee, LA., and Taylor, E.M., 1987, Stratigraphic, sedimentologic, and petrologic record of late Miocene subsidence of the central Oregon High Cascades: Geology, v. 15, p. 389-392.

Smith, G.A., and Taylor, E.M., 1983, The central Oregon High Cascades graben: What? Where? When?: Geothermal Resources Council Transactions, v. 7, p. 275-279.

Smith, G.A., Vincent, K.R., and Snee, L.W., 1989, An isostatic model for basin formation in and adjacent to the central Oregon High Cascades Range: U.S. Geological Survey Open-File Report 89-178, p. 411-429. 


\section{Hill and Priest}

Steigcr, R.H., and Jäger, E., 1977, Subcommission on geochronology: Cr svention on the use of decay constants in geoand cosmochronology: Earth and Planetary Science Letters, v. 36, p. 359:362.

Taylor, E.M., 1965, Recent volcanism between Three Fingered Jack and North Sister, Oregon Cascade Range: Ore Bin, v. 27-2, p. 121-147.

-1967, Recent volcanism between Three Fingered Jack and North Sister, Oregon Cascade Range: Pullman, Wash., Washington State University, Ph.D. dissertation, 84 p.

- 1981, Central High Cascade roadside geology--Bend, Sisters, McKenzie Pass, and Santiam Pass, Oregon: in DA. Johnston and J.Donnelly-Nolan, eds., Guides to some volcanic terranes in Washington, Idaho, Oregon and Northern California. U.S. Geological Survey Circular 838, p. 55-58.

-1990, Volcanic history and tectonic development of the central High Cascades Range, Oregon: Journal of Geophysical Research, v. 95, p. 19611-19622.

Walker, G.W., and Duncan, K.A., 1989, Geologic map of the Salem $1^{\circ} \times 2^{\circ}$ sheet, Oregon, scale 1:250,000: U.S. Geological Survey Miscellaneous Investigation Series Map I-1893.

Wendland, D.W., 1988, Castle Rocks: A late Miocene eruptive center at the north end of Green Ridge, Jefferson County, Oregon: Corvallis, Oreg., Oregon State University, M.S. thesis, 196 p.

White, C., 1980, Geology of the Breitenbush Hot Springs quadrangle, Oregon: Oregon Department of Geology and Mineral Industries Special Paper 9, 26 p.

White, C.M, McBirney, A.R., 1978, Some quantitative aspects of orogenic volcanism in the Oregon Cascades: Geological Society of America Memoir 152, p. 369-388.

Williams, H., and McBirney, A.R., 1979, Volcanology: San Francisco, Freeman, Cooper and Company, 397 p.

Yogodzinski, G.M., 1985, The Deschutes Formation - High Cascades transition in the Whitewater River area, Jefferson County, Oregon: Corvallis, Oreg., Oregon State University, M.S. thesis, 165 p. 
TABLE 3-1: Whole rock $K$-Ar ages, Santiam Pass 77-24 core

\begin{tabular}{|c|c|c|c|c|c|c|}
\hline $\begin{array}{l}\text { Ditpth } \\
\text { (ㅁiㄹ) }\end{array}$ & $\begin{array}{l}\text { Sample } \\
\text { wt (g) }\end{array}$ & $\begin{array}{c}K \\
(w t \%)^{9}\end{array}$ & $\begin{array}{l}{ }^{10} \mathrm{Ar}_{\text {rad }} \\
\times 10^{-12} \mathrm{~mol} / \mathrm{g}\end{array}$ & $\begin{array}{l}{ }^{40} \mathrm{Ar}_{\text {rad }} \\
18 \quad \%)\end{array}$ & $\begin{array}{c}\text { Age (Ma) } \\
( \pm 1 \sigma)\end{array}$ & Lithologic unit \\
\hline suré & 4.94 & 0.76 & 1.32 & 15.6 & $1.00 \pm 0.03$ & Basaltic andesite flow. \\
\hline 698 & 4.93 & 0.66 & 1.04 & 6.1 & $0.91 \pm 0.06$ & Basaltic andesite flow. \\
\hline 928 & 5.13 & 0.45 & 1.41 & 9.1 & $1.81 \pm C 05$ & Porphyritic basaltic andesite flow(?) \\
\hline
\end{tabular}

\section{Notes:}

$1 \varkappa$ determined by atomic absorption spectrometry at the University of Oregon, $C$. McBirney, analyst.

- Isotopic ratios determined at Oregon State University, R. Duncan, principal investigator.

- Decay constants: $\lambda_{e}=0.581 \times 10^{-10} \mathrm{yr}^{-1}, \lambda_{B}=4.962 \times 10^{-10} \mathrm{yr}^{-1}$, and ${ }^{40} \mathrm{~K} / \mathrm{K}_{\text {low }}=1.167 \times 10^{-4} \mathrm{~mol} / \mathrm{mol}$ (Steiger and Jäger, 1977).

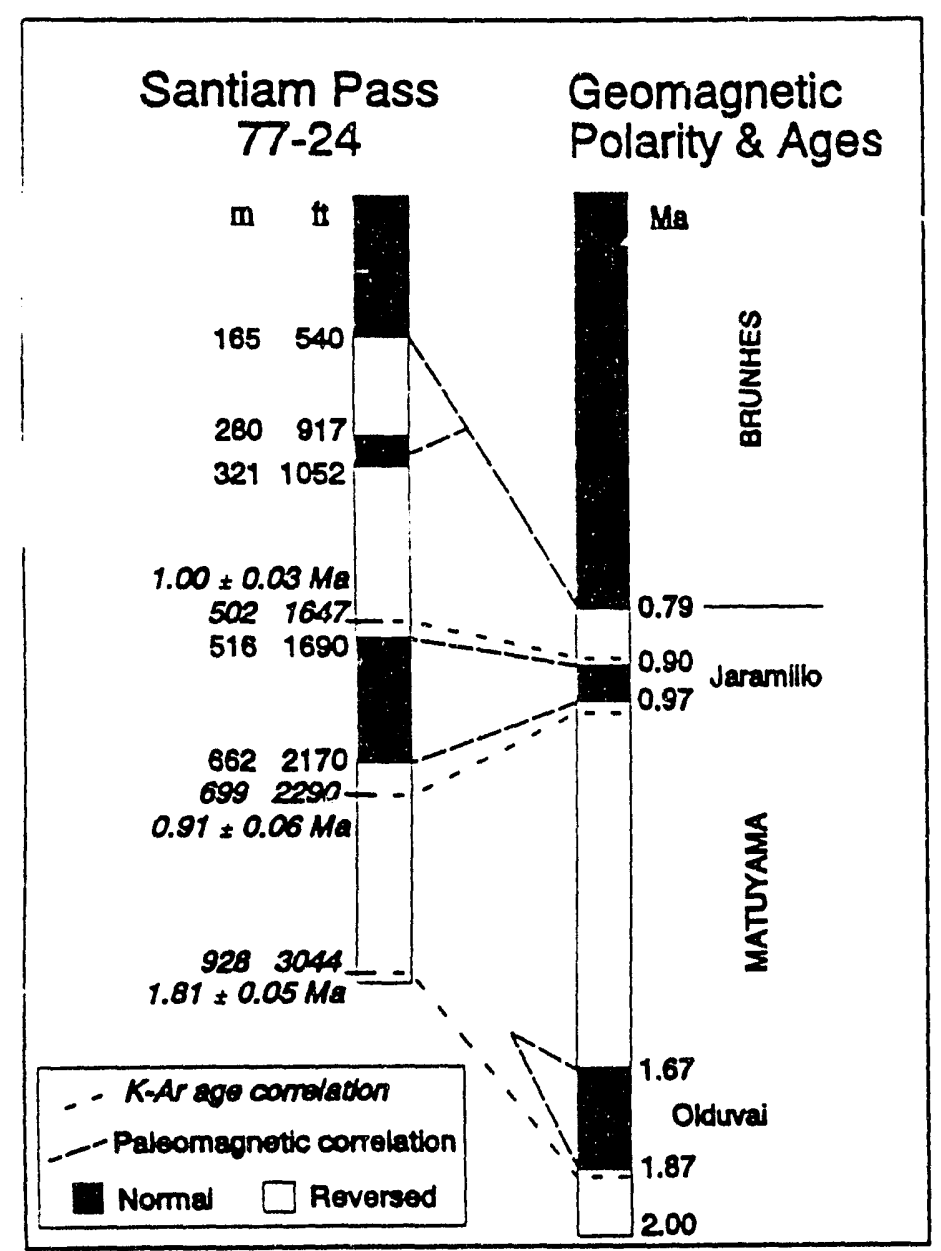

Fijure 3-1. Paleomagnetic and geochronologic correlations i. ween Santiam Pass core and the geomagnetic time scale of Inkinen and Dalrymple (1979). Core magnetization mea. sured with a flux-gate magnetometer.
The remnant magnetization of Santiam Pass core is summarized in Figure 3-1. The highest magnetic reversal in the core occurs at $165 \mathrm{~m}$ depth. The base of the magnetic normal section (Brunhes Normal-Polarity Chron) is also exposed along U.S. Highway $202.5 \mathrm{~km}$ east of the well site at an elevation of $\approx 1300 \mathrm{~m}$ (Plate 1 ), which corresponds to the elevation of this boundary in the Santiam Pass well. Core samples from $165 \mathrm{~m}$ to $260 \mathrm{~m}$ depth have reversed polarity magnetization, indicating an age of $>0.79$ Ma. A thick basaltic andesite flow at 260-343 $\mathrm{m}$ depth also has reversed polarity magnetization. However, basalt dikes with strong normal polarity magnetization cut this flow between $280 \mathrm{~m}$ and $321 \mathrm{~m}$ depth and have reset the sncereversely polarized flow to normal polarity (Figure 3-1).

Reverse-polarity basaltic andesite flows continue in the core to a depth of $516 \mathrm{~m}$. A K-Ar age of $1.00 \pm 0.03 \mathrm{Ma}$ for a basaltic andesite flow at $502 \mathrm{~m}$ depth might seem consistent with a pre-Jaramillo eruption age (Figure 3-1), but the $\mathrm{K}$-Ar ages and paleomagnetic orientations of deeper units indicate that this date is at least $0.1 \mathrm{Ma}$ too old. The 1.0Ma flow overlies a 146-m-thick magnetic-normal section, which in turn overlies a reverse polarity flow at $699 \mathrm{~m}$ with a K-Ar age of $0.91 \pm 0.06 \mathrm{Ma}$ (Figure 3-1). If the age of the 
underlying magnetically reversed flow is at the upper limits of 10 error (0.97-0.98 Ma), then the overlying magnetically normal flows were erupted during the Jaramillo event $0.90 \mathrm{Ma}$ to $0.97 \mathrm{Ma}$. This relationship would indicate that the age of the $502-\mathrm{m}$ flow is $<0.90 \mathrm{Ma}$, which is close to the lower limits of $1 \sigma$ error for this unit. However, an approximately 1 $\mathrm{Ma}$ age for the $502 \mathrm{~m}$ flow would require eruption of the underlying normal polarity flows during the 1.67-1.87 Olduvai event (Figure 3-1) and also would indicate that the $0.91 \pm 0.06$ age of the $699-\mathrm{m}$ flow was highly inaccurate. Thus, the age of the younger reverse polarity flow at $502 \mathrm{~m}$ is probably $\leq 0.90 \mathrm{Ma}$.

From $662 \mathrm{~m}$ to $929 \mathrm{~m}$ depth, mafic lava flows have reverse polarity magnetization. Several basalt dikes at $690 \mathrm{~m}$ and $709 \mathrm{~m}$, which are chemically and lithologically indistinguishable from basalt dikes above $650 \mathrm{~m}$, have normal polarities. All the basalt dikes are probably younger than $0.79 \mathrm{Ma}$, because they intrude reverse polarity rocks that are younger than $0.90 \mathrm{Ma}$ (post-Jaramillo age). Some of the mafic flows within $1 \mathrm{~m}$ of these dikes have paleomagnetic orientations that have been reset from strongly reversed to weakly normal.

A debris-flow deposit at $843 \mathrm{~m}$ depth also has a consistent but weak normal polarity. The matrix of this deposit is only slightly indurated, which suggests that the deposit was not hot enough to accurately record the paleomagnetic orientation. The normal magnetic direction in this unit is probably a relict of hydration and oxidation of ferromagnesian minerals during the Brunhes Normal-Polarity Chron and does not indicate deposition during the Olduvai Normal-Polarity Subchron (Figure 3-1). All units beneath this debris flow have reverse polarity magnetization. A reversely polarized flow at $928 \mathrm{~m}$ depth has a K-Ar age of $1.81 \pm 0.05 \mathrm{Ma}$, which is within the uncertainty for the lower age limit of the Olduvai Normal-rolarity Subchron (Mankinen and Dalrymple, 1979).

\section{CORE PETROLOGY}

Previous studies of mafic High Cascade volcanism by McBirney and others (1974), Priest and others (1983), Hughes (1983, 1990), Hughes and Taylor (1986), and Conrey and Sherrod (1989) L...jve shown that the central Oregon High Cascades consists of overlapping mafic shield and composite volcanoes. These studies have generally concluded that the mafic magma system is open to variable amounts and types of crystal fractionation, crustal assimilation, magma mixing, and magma recharge. Variations in the expression of each of these petrogenetic processes has resulted in the production of several apparently different mafic magma types (Hughes, 1990), although it is not clear if some $c^{f}$ thesi supposedly distinct magmas result from limited sampling of the mafic system (Conrey, 1991; Hill, 1991). Each of these petrogenetic processes could also be dominant at different locations or at specific times during the late High Cascades eruptive episode. Previous studies have not rigorously tested for spatial or temporal variations in mafic magma petrogenesis because the stratigraphic and temporal relationships between different volcanoes of the High Cascades are poorly constrained. A further limitation to these previous studies is that only a few analyses a:e available for each mafic volcanic center.

The Santiam Pass core represents a unique vertical sampling of at least 1 m.y. of relatively continuous mafic volcanism on the axis of the central Oregon High Cascades. The hypothesis that there are temporal variations to mafic petrogenesis can be tested through study of the Santiam Pass core. In addition, the Santiam Pass area is representative of the High Cascades away from major stratovolcanic magma systems. The Santiam Pass core thus aids in understanding the geologic processes that control petrogenesis of mafic magmas in the Oregon High Cascades. 


\section{Petrographic characteristics}

The Santiam Pass core contains 29 chemically and petrographically distinct lava flows and two types of basaltic dikes. The distribution of each flow type in the core is shown in the summary lithology log (Figure 3-2). Petrographic characteristics of the Santiam Pass core are summarized in Appendix 1.

Basalt lavas (i.e., $\leq 53$ percent $\mathrm{SiO}_{2}$ ) are characterized by a plagioclase-olivine assemblage, with subordinate amounts of clinopyroxene. Orthopyroxene is only found in those basalts with subophitic groundmass textures. Most plagioclase phenocrysts in the basalts contain a few glass inclusions and have weak normal zoning, which are characteristics of nearequilibrium crystallization. Basalt dikes contain phenocrysts of plagioclase and olivine, with only a trace amount of clinopyroxene observed at $523 \mathrm{~m}$. Piagioclase phenocrysts in the dikes lack glass inclusions and have weak normal zonation. The basalt dikes are always vesicular, and the groundmass commonly has a diktytaxitic texture.

Basaltic andesite lavas ( 53 percent to 58 percent $\mathrm{SiO}_{2}$ ) range from plagioclase-olivine phyric from 53-54 percent $\mathrm{SiO}_{2}$, to plagioclase-two pyroxe! assemblages from 55-57 percent $\mathrm{SiO}_{2}$. Plagioclase phenocrysts in many basaltic andesite lavas contain abundant coarse glass inclusions and have strong normal zoning, which are characteristics of disequilibrium crystallization commonly associated with magma mixing (Lofgren, 1980; Sakuyama, 1981). Other disequilibrium crystallization features in the basaltic andesites include resorbed and opacitic olivine, olivine with orthopyroxene reaction rims, and reversely zoned plagioclase with fritted and embayed margins.

The basaltic and basaltic andesitic lavas show many common deuteric alteration effects, including iddingsite and opacitic alteration of olivine and oxidation of phenocryst and groundmass ferromagnesian minerals. Possible features of low-temperature ( $\leqslant 50^{\circ} \mathrm{C}$; Keith, 1988) hydrothermal alteration consist of patchy alteration of groundmass glass to clays and rare zones of radiai zeolites associated with tractures at $466 \mathrm{~m}$ and below about $760 \mathrm{~m}$. Alteration of ferromagnesian minerals to slightly pleochroic mixtures of chlorite(?) + clays below about $730 \mathrm{~m}$ may indicate alteration temperatures between $50^{\circ}-100^{\circ} \mathrm{C}$ (Keith, 1988).

Volcaniclastic rocks comprise approximately 5 percent of the core. Coarse-graired (6-2 cm clasts) debris-flow deposits range in thickness from $15 \mathrm{~m}$ to $7.5 \mathrm{~m}$ in the core. Clasts in these deposits are predominantly mafic volcanics, although fine-grained diorite(?) clasts as large as $1 \mathrm{~cm}$ in diameter are locally found at $659 \mathrm{~m}$ and $853 \mathrm{~m}$. Other volcaniclastic rocks include primary and reworked beds of mafic cinders and ash as thick as $1 \mathrm{~m}$ and sequences of coarsely bedded voicanic sandstones amassing $3 \mathrm{~m}$ in total thickness. Highly oxidized autobreccias are found at the base and top of many mafic lava flows, along with intratlow breccias.

\section{Geochemistry}

A total of 41 lava samples, representing all major igneous units in the core, were analyzed by X-ray fluorescence (XRF). A 20 sample subset was analyzed by inductively coupled plasmaspectrometry (ICP), and 12 samples were analyzed by instrumental neutron activation analysis (INAA). Descriptions of analytical methods are given in Appendix 2. Some samples were analyzed by several techniques, resulting in multiple values for some elements. All of the analyses for each sample are reported in Appendix 3, along with a ranking of the relative precision and accuracy for each analytical technique. The abundances from most precise and accurate technique for these samples are given in Table 3-2 and are used in the following petrologic discussions. 
SANTIAM PASS 77-24

Summary Lithologic Log

EXPLANATION

Wthologles based on hand-sample identfication and major element analyses

IIII Basalt flow, $<53 \%$ SiO2

|||||||||| Baselt dike

Mafic flow breccia

2.) Debris-flow deposit

Mafic near-vent agglutinate

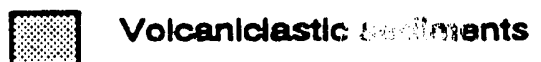

उद3Z Basaltic andesite flow, $53 \%-58 \%$ SiO2

$\square$ Thin section on t.

- Geochemistry oniy

Cpx: Clinopyroxene

ala: as above

Geochemistry + thin section Mag: Magnetic polarty

Normal $\square$ Reversed ? Uncertain

Scale : $1^{\prime \prime}-100^{\prime}$

ROTARY DRILLING LOG

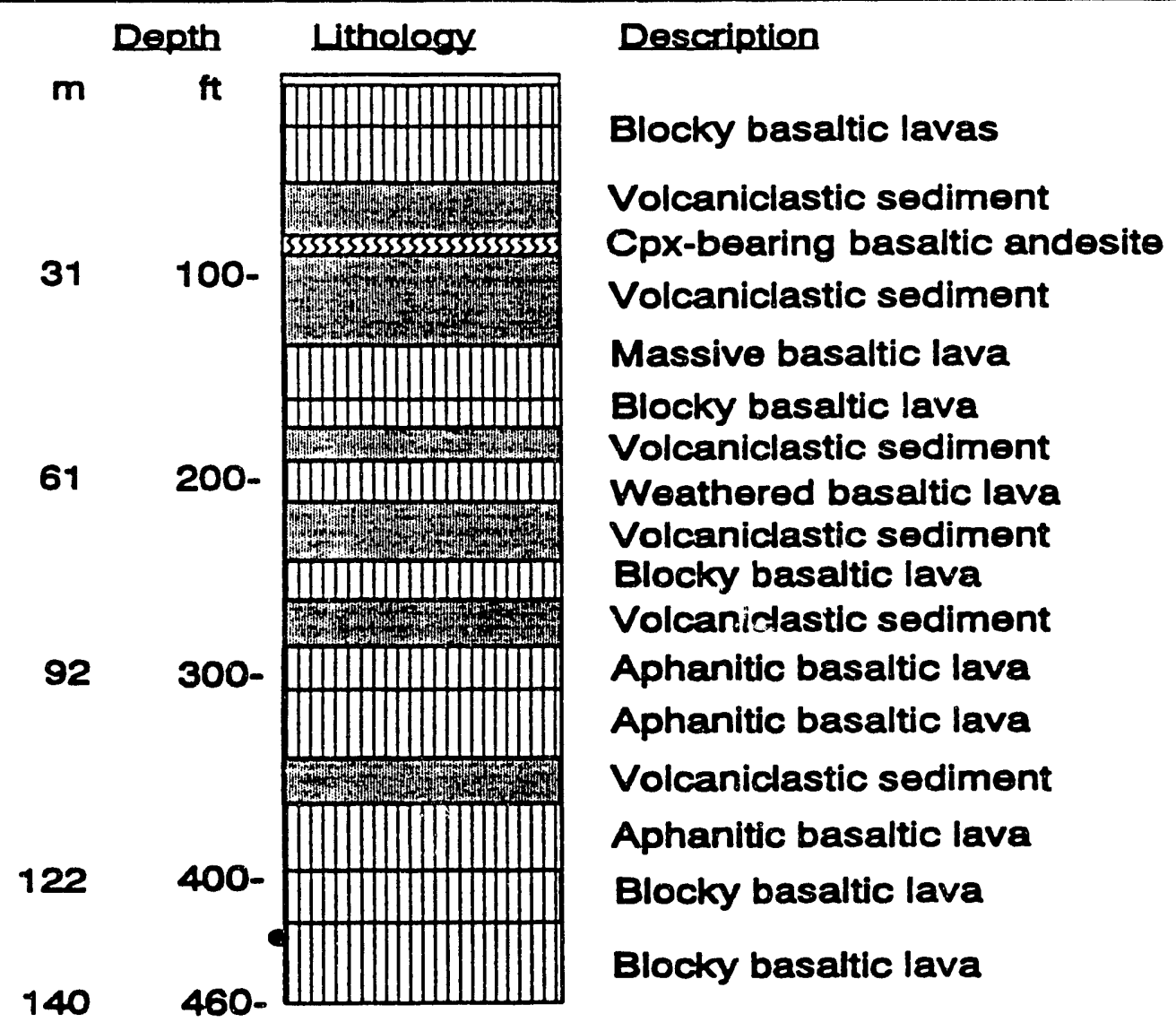

Figure 3-2. Summary lithologic log for Santiam Pass 77-24 drill core. 


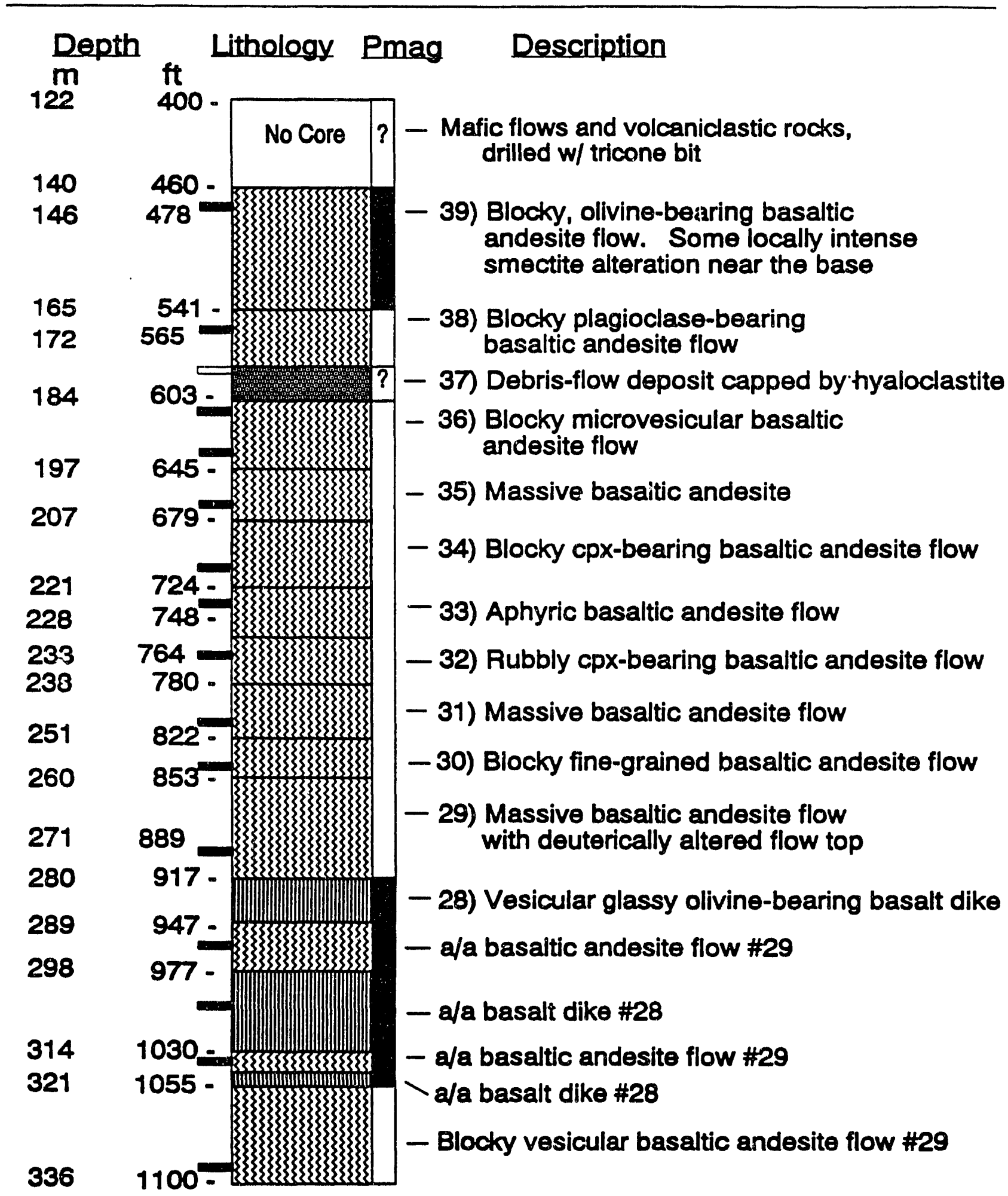

Figure 3-2, continued. 


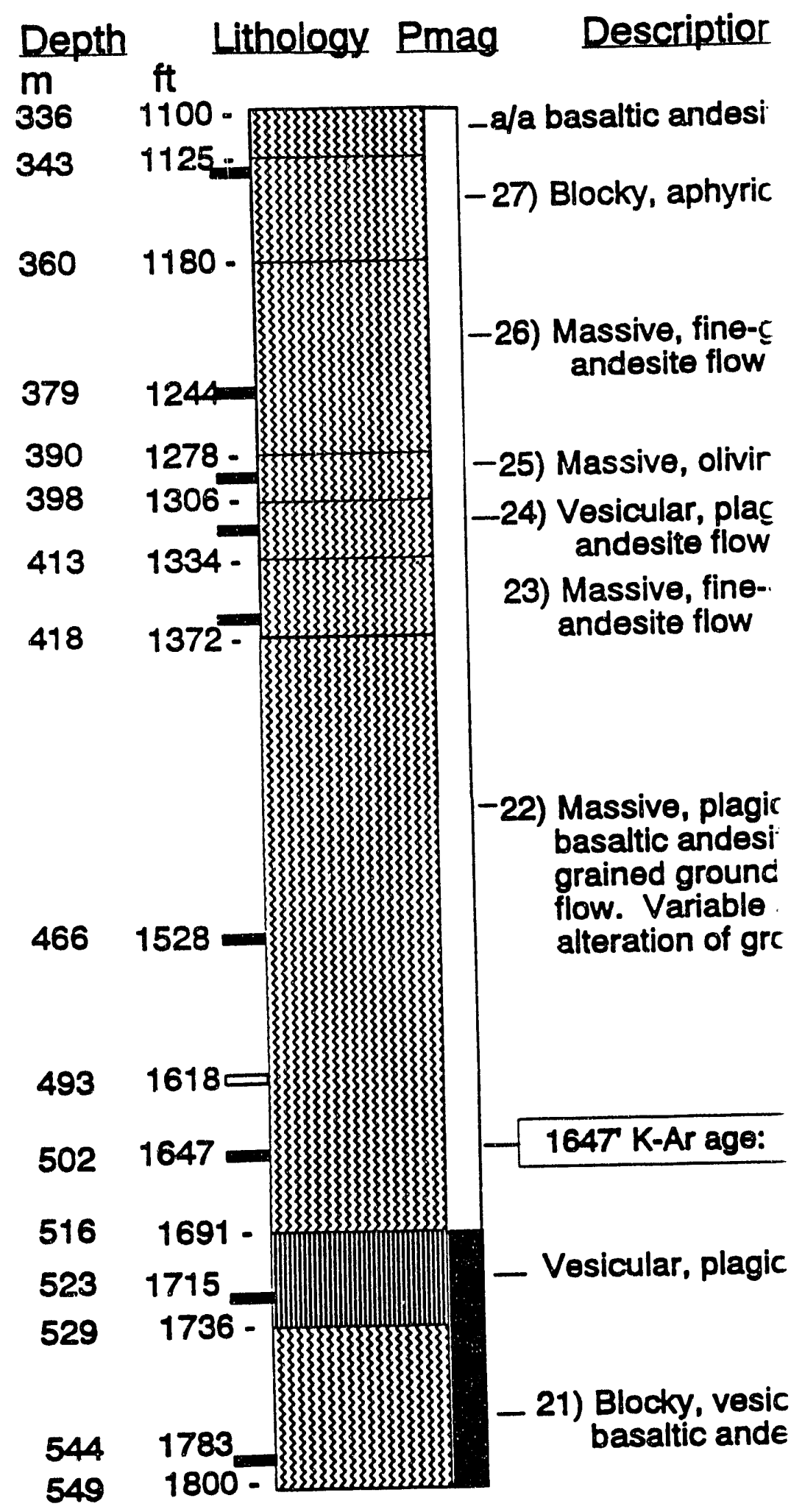

Figure 3-2 continued. 


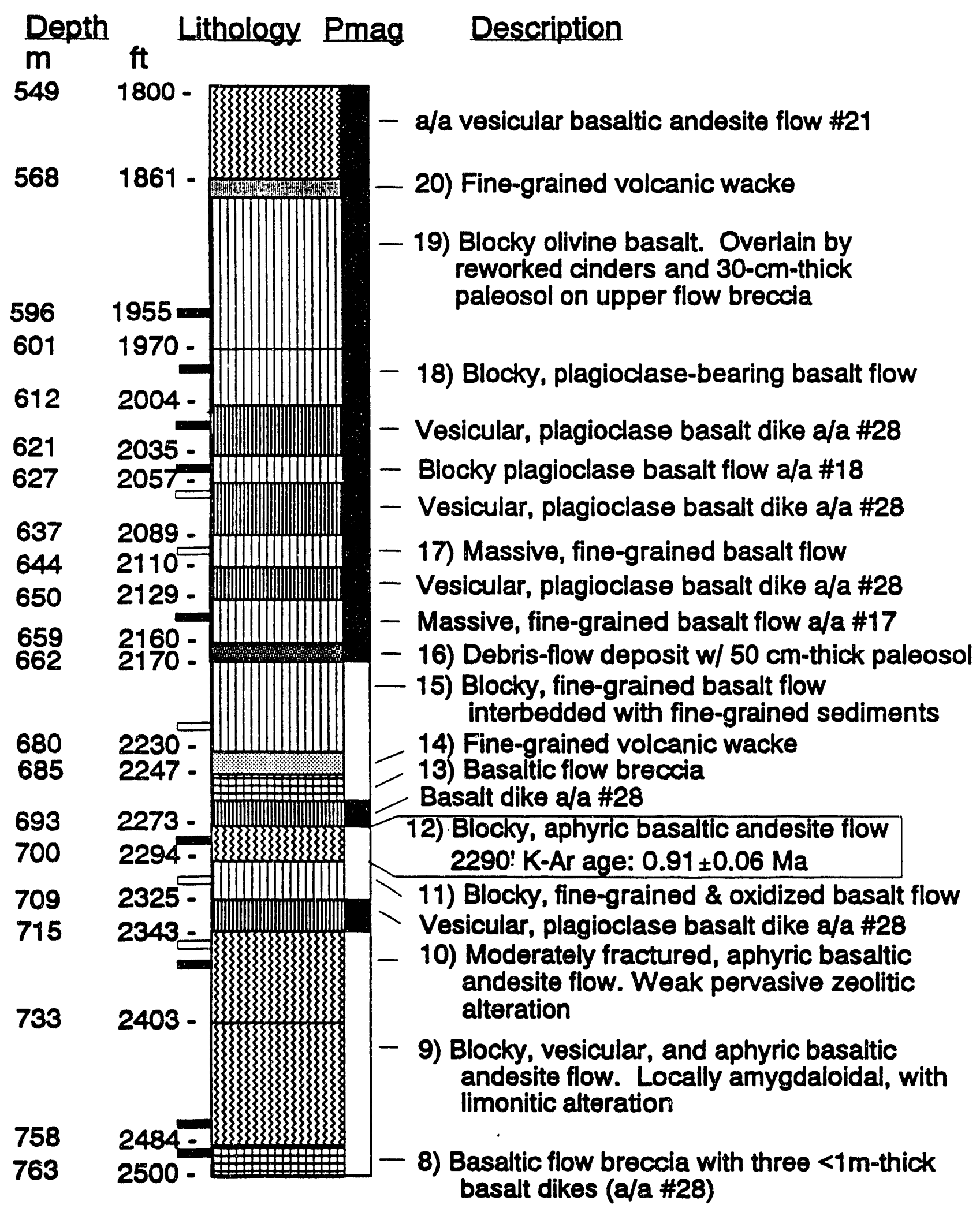

Figure 3-2, continued. 


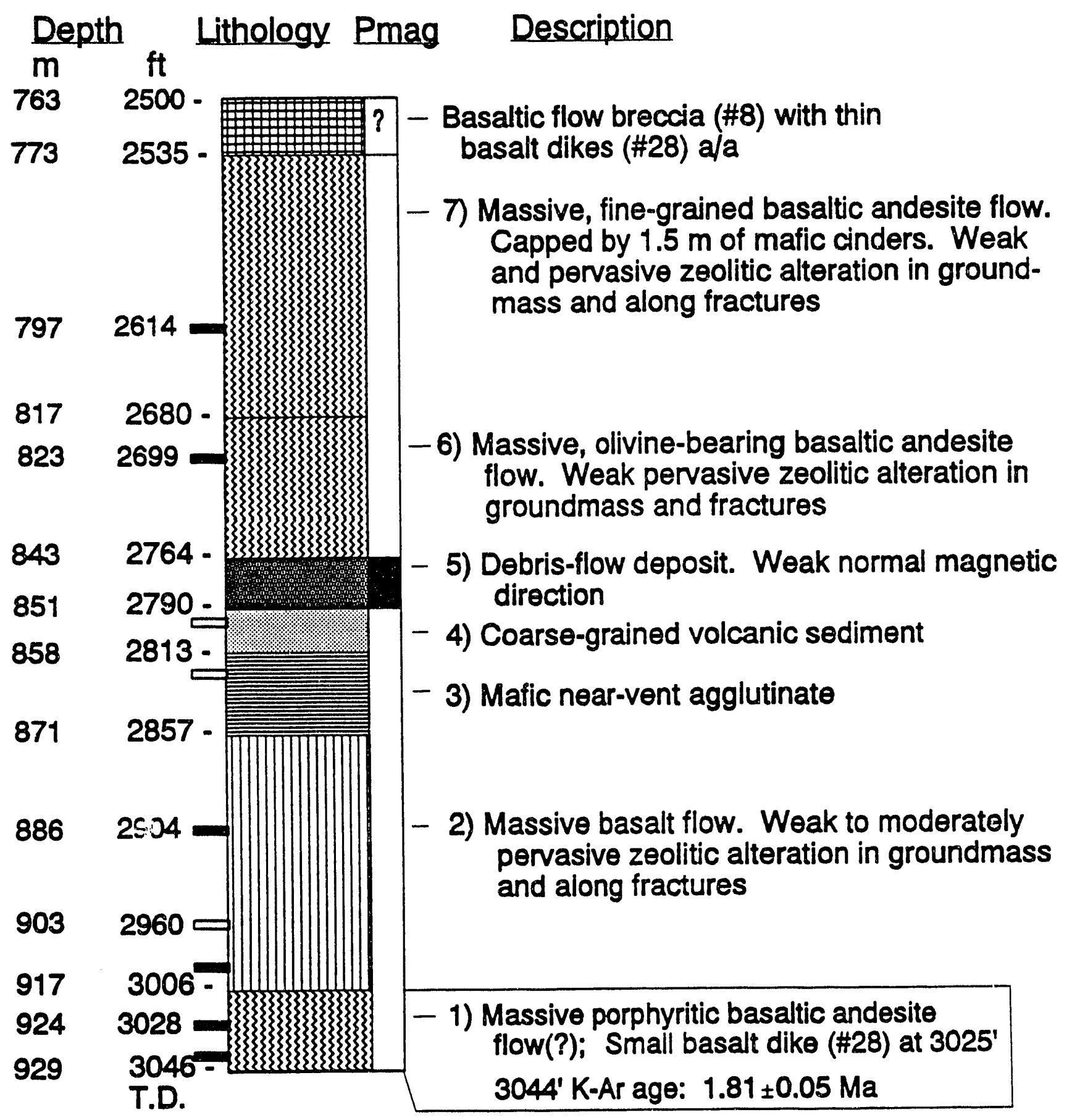

Figure 3-2, continued. 


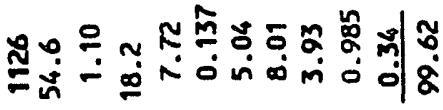

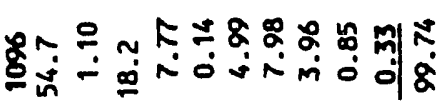

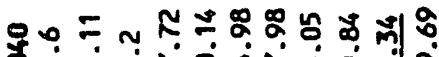

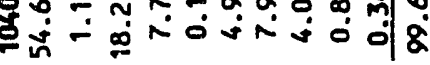

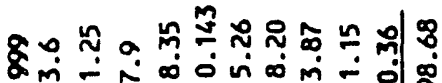
n一-

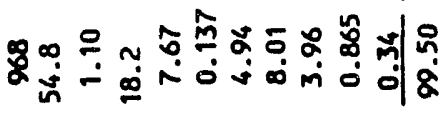

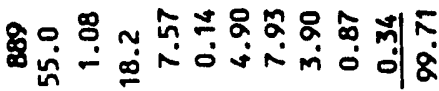

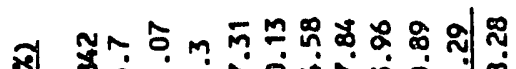
추

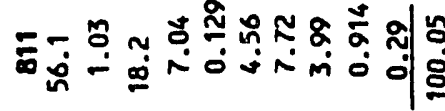

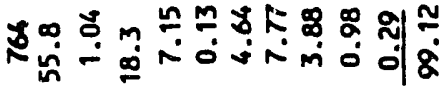
Rูn 웅 क

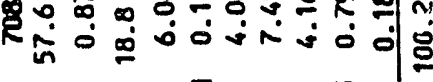

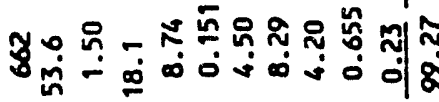

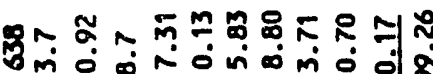

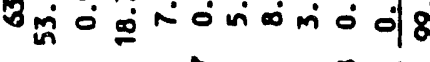

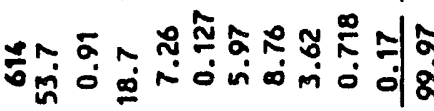

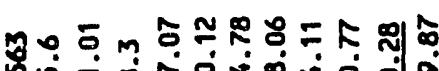

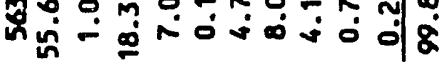

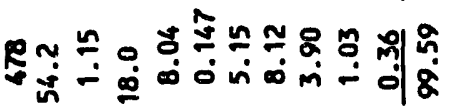

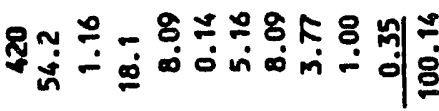

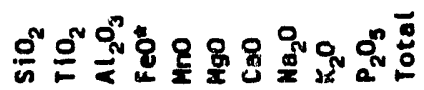

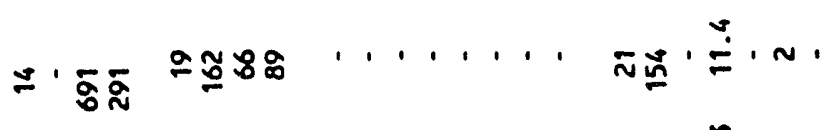

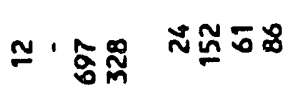

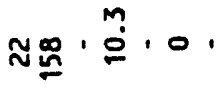

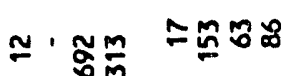

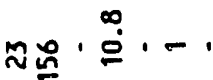

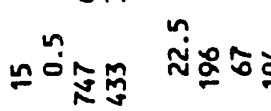

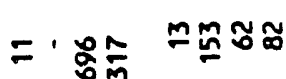

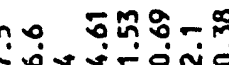

maño

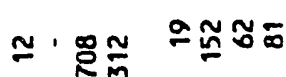

$$
\begin{aligned}
& \text { 经 } \check{E} .
\end{aligned}
$$

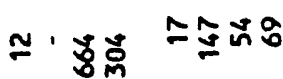
$\underline{a} \overline{\underline{g}} \cdot \bar{\cdot} \cdot$

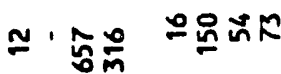

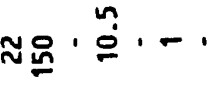

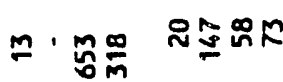

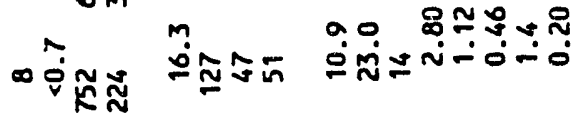
욤ํำ. ำรักิ

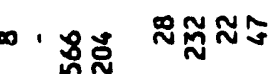
กヘฺ̄ต̣

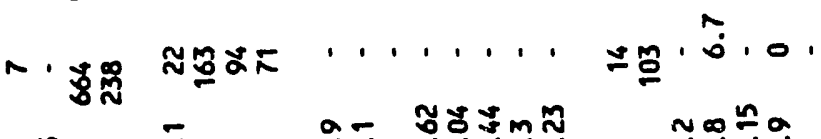

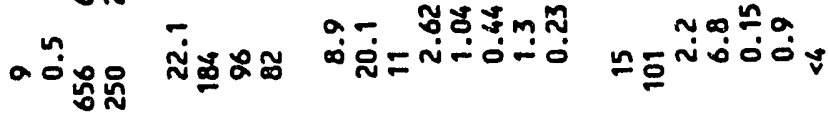

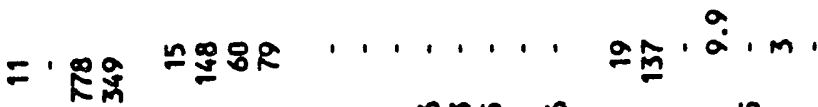

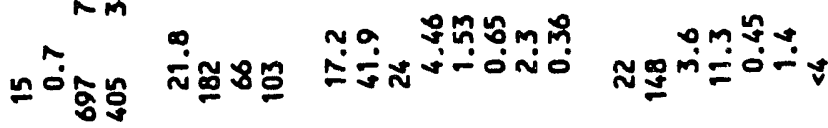
ํํำ กㅌำ N

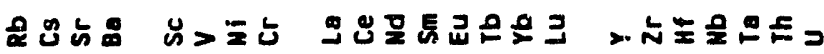




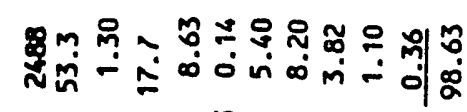

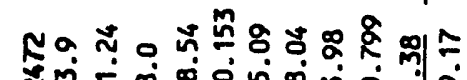

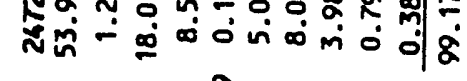

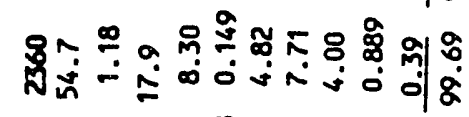

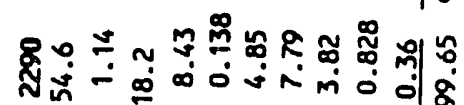

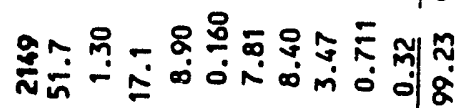

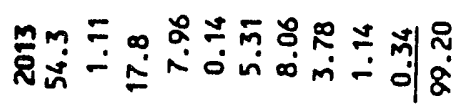
夷-

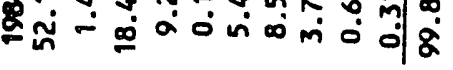

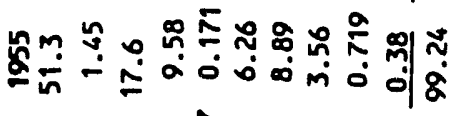

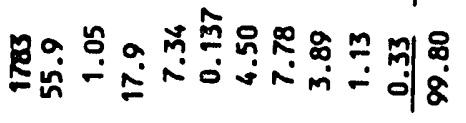

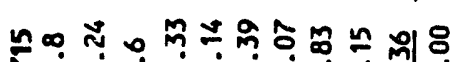

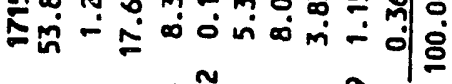

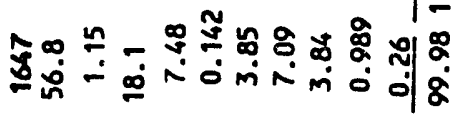

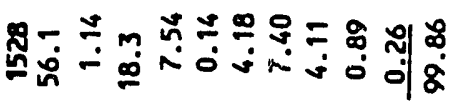

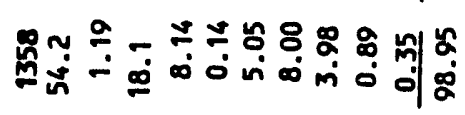

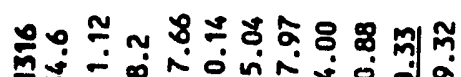

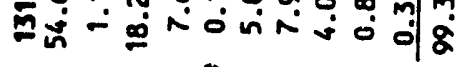

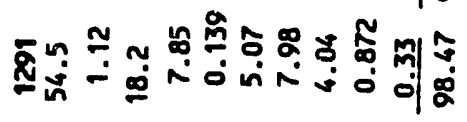

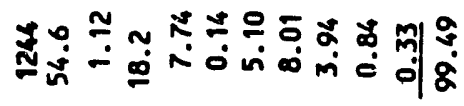

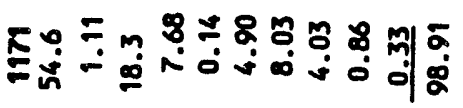
ต์

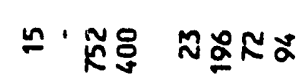

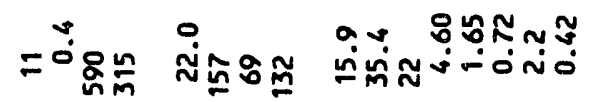

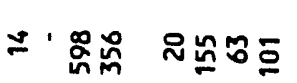

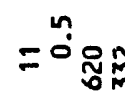

वค्่ำำ

ธิฐฐช

กั

ำ橆

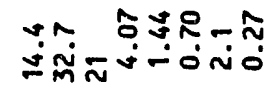

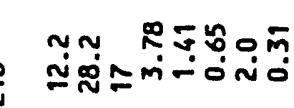

$$
\text { : }
$$

$$
\begin{aligned}
& = \\
& = \\
& =
\end{aligned}
$$

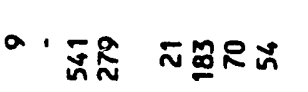

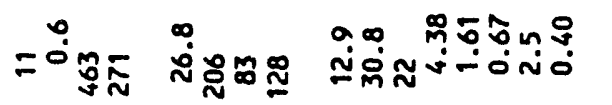

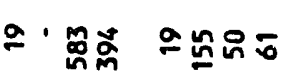

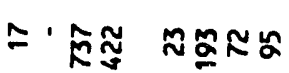

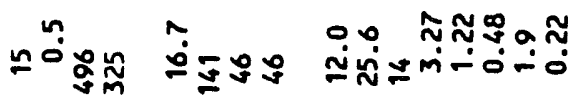

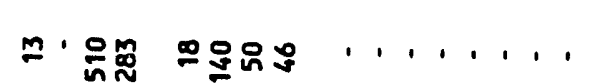

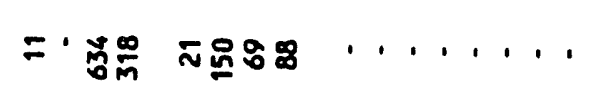

高解

ㅇํำ

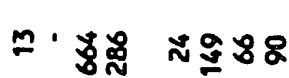

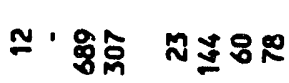

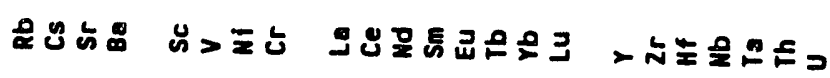


T-

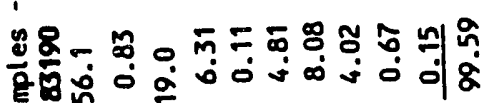

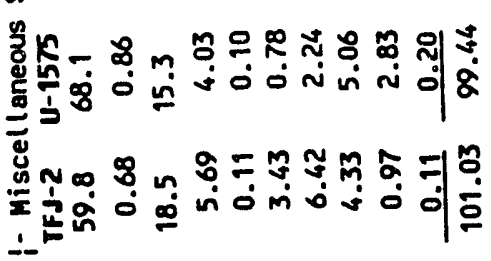

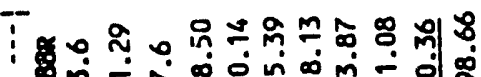

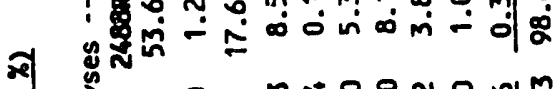

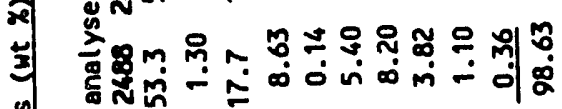

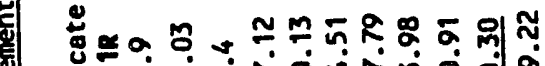

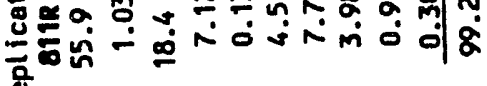

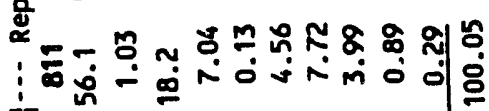

ะ น ถ

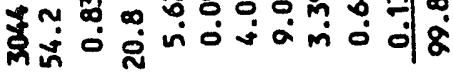

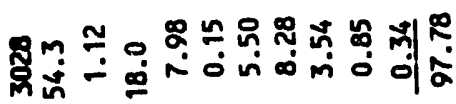

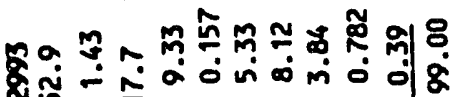
英宜 so

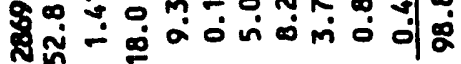

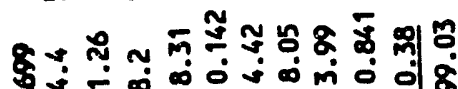

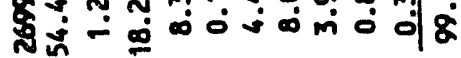

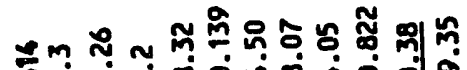

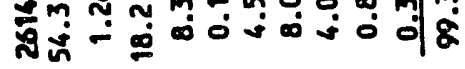

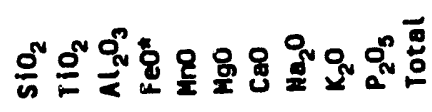

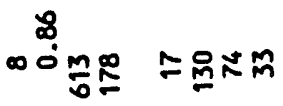

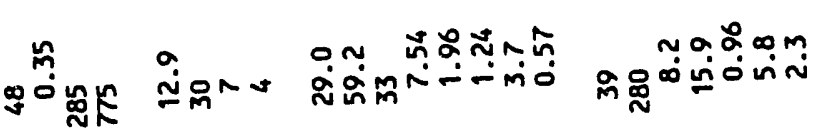

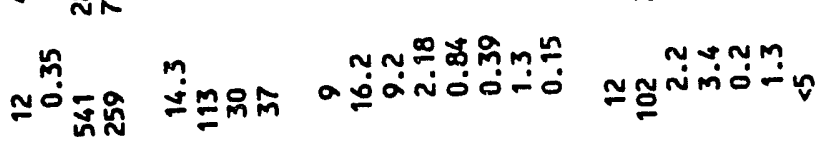

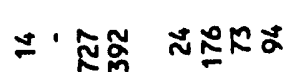

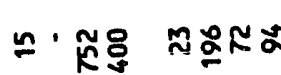

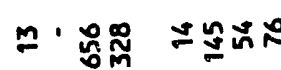

ㄴํำำำำ

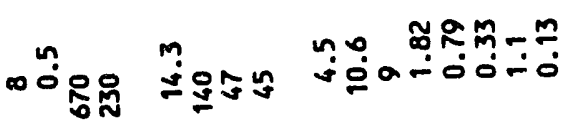

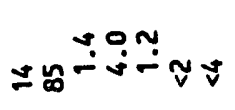

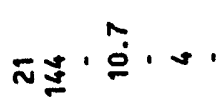

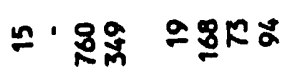

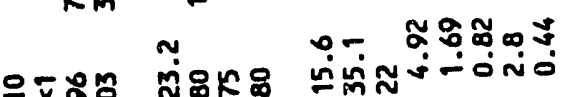

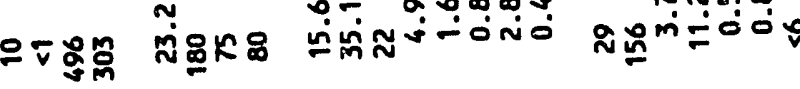

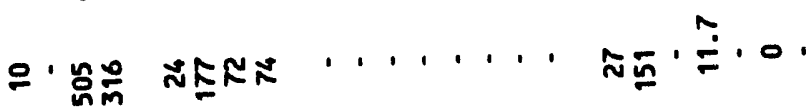

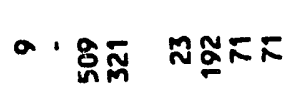

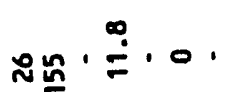

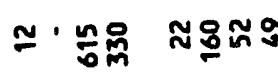

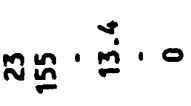

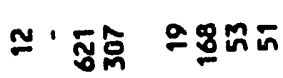

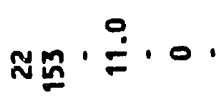

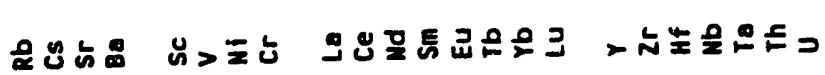


Many rocks in the Santiam Pass core have undergone pervasive, deuteric alteration, which is apparently overprinted by low-temperature $\left(\leq 50^{\circ} \mathrm{C}\right)$ bydrothermal alteration below about $730 \mathrm{~m}$. The geochemical effects associated with this type of alteration are oxidation and hydration of primary $\mathrm{Fe}$-Ti oxides and limited alkaline element ( $\mathrm{Na}, \mathrm{K}, \mathrm{Rb}$ ) mobility. The large variations in $\mathrm{Fe}_{2} \mathrm{O}_{3} / \mathrm{FeO}^{\circ}$ with depth in Figure 3-3a are indicative of post-emplacement oxidation and alteration.

$\mathrm{Zr}$ and $\mathrm{Nb}$ are two elements essentially incompatible during the differentiation of mafic magmas and are also relatively immobile during low-temperature alteration. Significant variations in $\mathrm{Zr} / \mathrm{Nb}$ ratios will be a sensitive indicator of changes in the compositions of parental magmas or crustal assimilant. The variations in $\mathrm{Zr} / \mathrm{Nb}$ observed in the Santiam Pass core do not show systematic changes with depth (Figure 3-3b), thereby indicating that potentially different types of mafic petrogenesis in this part of the High Cascades do not vary in any simple way with time. A limited number of $\mathrm{Ba} / \mathrm{La}, \mathrm{Zr} / \mathrm{Hf}$ and $\mathrm{Nb} / \mathrm{Ta}$ analyses of the Santiam Pass core also fail to show significant variations with depth.
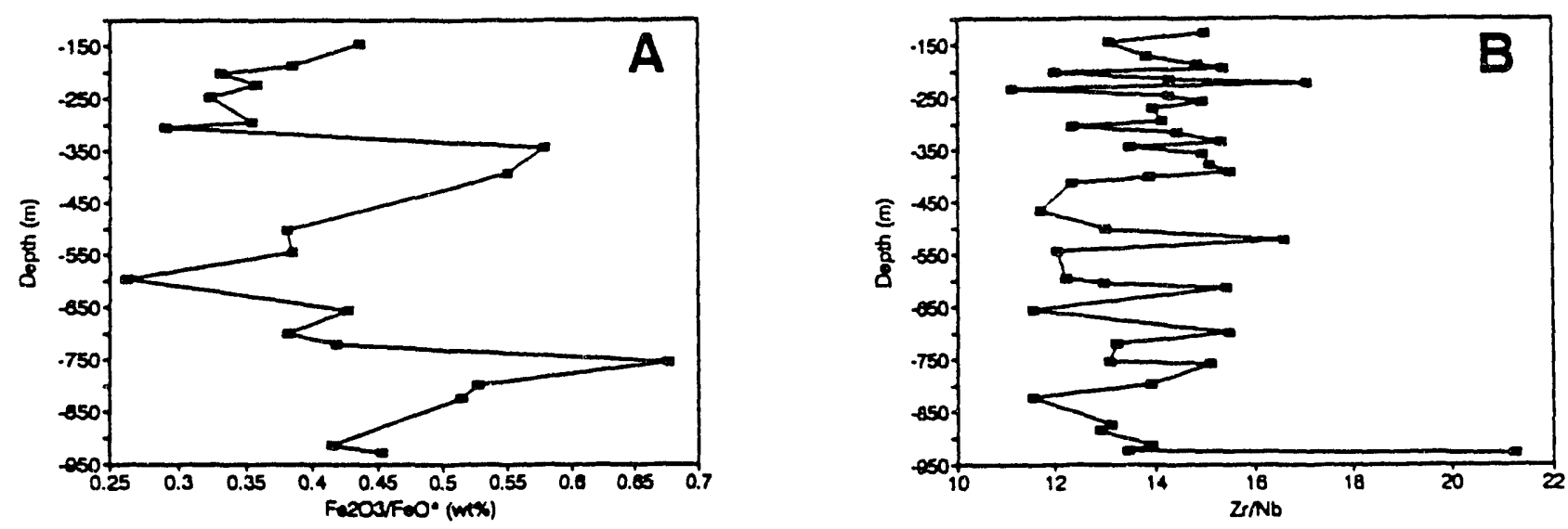

Figure 3-3. (A) Large variations in $\mathrm{Fe}_{2} \mathrm{O}_{3} / \mathrm{FeO}^{\circ}$ with depth are the effects of deuteric and low-temperature hydrothermal alteration of mafic lavas in the Santiam Pass core. (B) The small observed variations in $\mathrm{Zr} / \mathrm{Nb}$ with depth indicate a similar petrogenesis for all rocks in the Santiam Pass core, with the exception of the basaltic andesite at $929 \mathrm{~m}$.

Hughes $(1983,1990)$ and Hughes and Taylor (1986) distinguished four chemically distinct mafic rock types in the $\leq 2 \mathrm{Ma}$ Three Sisters-Three Fingered Jack area: Normal basalt, divergent basalt, North Sister basaltic andesite and Mount Washington basaltic andesite. These analyses were used to define the fields in Figures 3-4a and 3-4b. Other late High Cascades analyses in Figures 3-4a and 3-4b are from Davie (1980), Conrey (1991; unpub. data, 1991) and Hill (unpub. data, 1991). These data, combined with analyses from the Santiam Pass core, show that mafic rocks in this area cannot be simply defined by four compositional types. Late High Cascades mafic rocks, including those from the Santiam Pass core, can belong to either tholeiitic or calc-alkaline assemblages (Figure 3-4a). In addition, these rocks have a wide range in $\mathrm{TiO}_{2}$ content for any given amount of differentiation (Figure 3-4b).

The compositions of late High Cascades mafic rocks are also very similar to the compositions of early High Cascades (7-5 Ma) rocks exposed at Green Ridge. Using data from Conrey (1991; unpub. data, 1991), the Santiam Pass analyses show the same range of variation as the Green Ridge analyses (Figures 3-4c and 3-4d). Although the average composition 

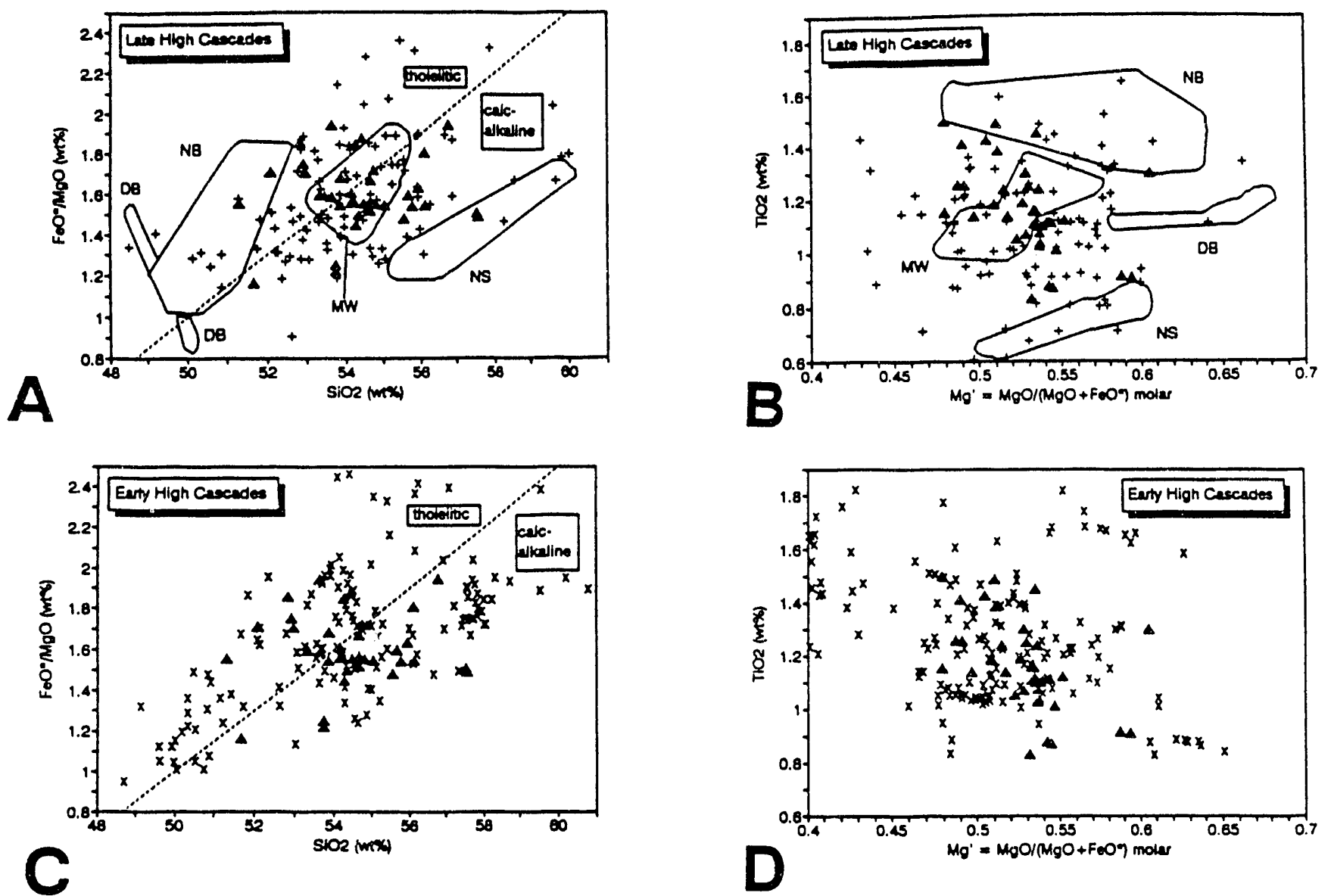

Figure 3-4. (A) Plot of $\mathrm{FeO} * / \mathrm{MgO}$ vs. $\mathrm{SiO}_{2}$ for Santiam Pass samples (ه) and surficial volcanic rocks between North Sister and Three Fingered Jack (+). Fields for normal basalts $(N B)$, divergent basalts (DB), Mt. Washington type basaltic andesites (MW) and North Sister type basaltic andesites (NS) from Hughes (1983, 1990); tholeiitic and calc-alkaline fields from Miyashiro (1974). (B) Variations in $\mathrm{Mg}^{\prime}$ vs. $\mathrm{TiO}_{2}$ for late High Cascades rocks, using same symbols and fields definitions as in part $A$. (C) \& (D) Comparisons of earty High Cascades (x) and Santiam Pass (A) rocks, same fields as parts $A \& B$.

of Green Ridge rocks is somewhat more tholeitic (Figure 3-4c) and titaniferous (Figure 3-4d) than late High Cascades rocks, the ranges in composition for individual analyses are nearly indistinguishable for early and late High Cascades rocks.

Similar trends between early and late High Cascades mafic rocks are also observed for many trace elements. Incompatible elements such as $\mathrm{Ba}$ (Figure 3-5a) show expected increases with increasing $\mathrm{SiO}_{2}$ content for both early and late High Cascades rocks. The overall trends between early and late High Cascades mafic rocks are indistinguishable, although individual samples may plot outside the range of the other age group. For example, some late High Cascades basaltic andesites have lower $\mathrm{Ba}$ than that observed in early High Cascades basaltic andesites (Figure 3-5a). This may reflect evolution of some late High Cascades basaltic andesites from parental magmas with initial Ba concentrations lower than early High Cascades basalts, or the mixing of lower Ba magmas or wall rocks into the late High Cascades mafic system. Incompatible element distributions indicate a similar petrogenesis for most early and late High Cascades mafic rocks. 

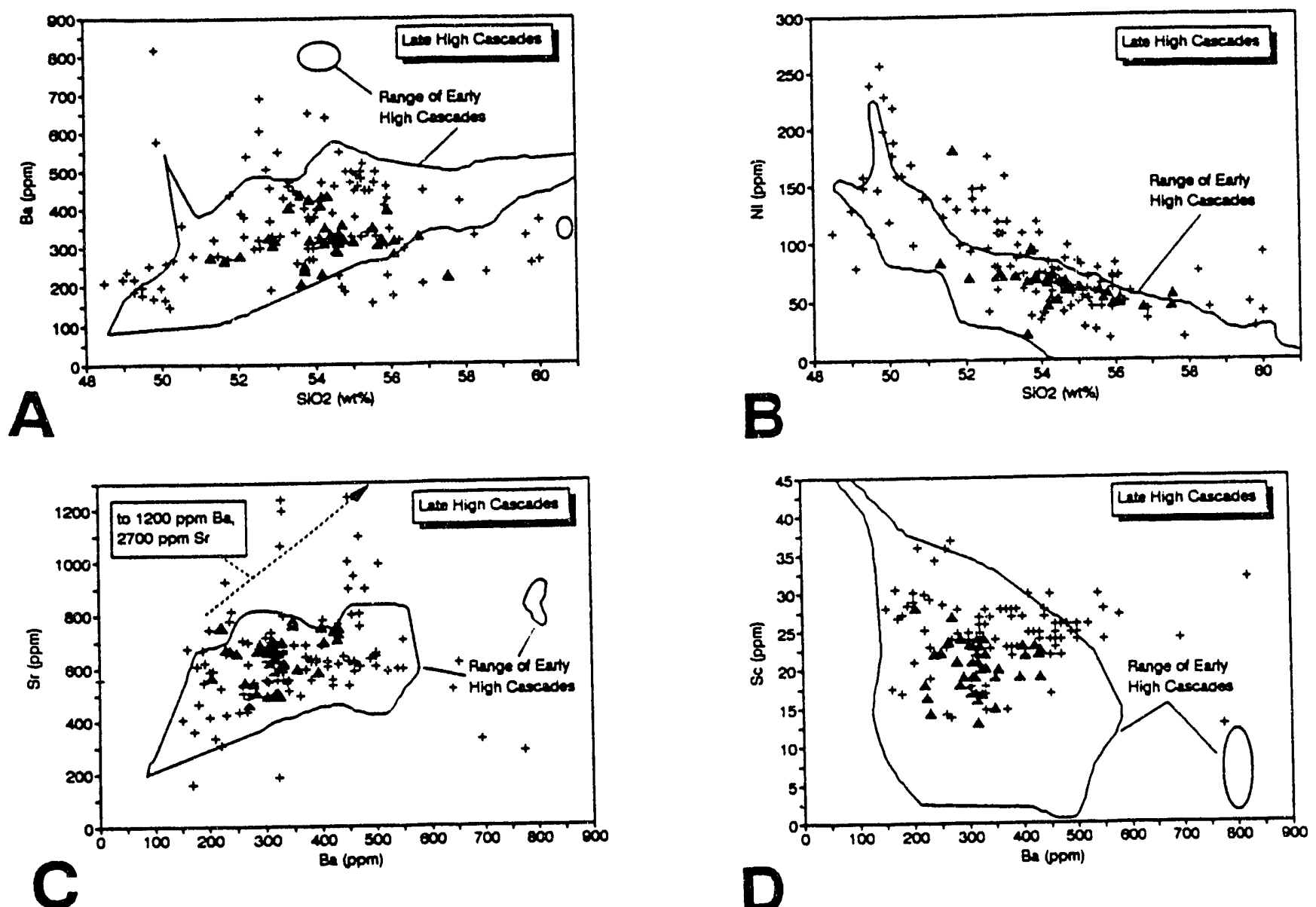

Figure 3-5. (A) Representative incompatible element variations with $\mathrm{SiO}_{2}$ for Santiam Pass ( 1 ) and late High Cascades surficial rocks (+). Range of earty High Cascades compositions from Conrey (1991). (B) Representative compatible element variations with $\mathrm{SiO}$, same symbols as in par $A$. Late High Cascades basalts have slightly higher Ni concentrations than earty High Cascades basalts. Both ages of mafic rocks have very similar incompatible element abundances. Compatible-incompatible element variations in $(C)$ and $(D)$ also indicate that earty and late High Cascades mafic rocks have a similar petrogenesis.

Compatible-element variations show some subtle distinctions between early and late High Cascades rocks. For example, $\mathrm{Ni}$ abundances (Figure 3-5b) are somewhat higher in late High Cascades rocks relative to compositionally similar early High Cascades rocks. These variations may indicate that more olivine is fractionated from some early High Cascades magmas, that mixing of low-Ni melts is at times more prevalent in the early High Cascades magma system, or that late High Cascades magmas have more of a parental recharge component than in the early High Cascades. The overall compatible element trends, however, still show considerable overlap, which makes it difficult to distinguish an early or late High Cascades provenance for any individual sample.

Correlation of compatible-incompatible-element abundances in the late High Cascades are very similar to correlations in the early High Cascades (Figures 3-5c and 3-5d). Although there is considerable overlap between these two age groups, the relatively lower abundances of Sc at equivalent Ba concentration in the early High Cascades may indicate that fractionation of clinopyroxene or mixing of low-Sc magmas was more prevalent than during late High Cascades magmatism. A lack of low-Sc mafic magmas in the late High Cascades may also indicate that more mafic 
recharge occurred in the late High Cascades magma system. Sr-Ba variations (Figure 3-5d) between early and late High Cascades rocks are also very similar, although elevated $\mathrm{Sr}$ and $\mathrm{Ba}$ in some late High Cascades rocks may indicate assimilation of high-Sr and -Ba crustal rocks. In addition, some early High Cascades basaltic andesites have higher $\mathrm{Sr}$ than similar composition late High Cascades rocks, which may indicate that these early High Cascades rocks differentiated with relatively low amounts of plagioclase fractionation.

\section{PETROGENETIC SUMMARY}

Mafic rocks in the Santiam Pass core are indistinguishable from other late High Cascades mafic rocks in the North Sister-Three Fingered Jack area. In addition, the analyses from the Santiam Pass core and other analyses not present in the original data base of Hughes $(1983,1990)$ and Hughes and Taylor (1986) clearly show that these mafic rocks cannot be simply divided into four separate groups. Petrographic and geochemical data indicate that mafic rocks evolved from a long-lived mafic magma system that was open to variable amounts of magma recharge, crystal fractionation, magma mixing, and crustal assimilation. There is no apparent systematic variation in the expression of these magmatic processes with either time or space in both the High Cascades, or within the Santiam Pass core. Mafic rocks from the Green Ridge area, which are representative of early High Cascades magmatism (Conrey, 1985, 1991), cannot be readily distinguished from late High Cascades mafic rocks on the basis of mineralogy or chemistry. Some early and late High Cascades mafic rocks may have evolved under different magmatic conditions, although there is no compelling evidence that indicates either of these mafic systems were petrogenetically distinct.

\section{ACKNOWLEDGMENTS}

I thank Dick Benoit, Oxbow Geothermal Corporation, for his and Oxbow Geothermal's enthusiasm and support of the Santiam Pass drilling program. Richard Conrey generously provided a compilation of his published and unpublished analyses of the Green Ridge and south Mt. Jefferson-Three Fingered Jack area. The careful reviews of George Priest, Edward Taylor and David Sherrod, and numerous conversations with Conrey, Priest, Taylor, and Scott Hughes have focused and greatly improved this chapter. Some of the analytical work on the Santiam Pass core would not have been possible without the help and direct support of Howard Ross and Ruth Kroneman, University of Utah Research Institute (ICP); and Robert Walker and Art Johnson, Radiation Center, Oregon State University (INAA). I also thank Conrey, Peter Hooper, and Diane Johnson, Washington State University, Pullman; and Robert Duncan and William Gallahan, Oregon State University, for their expert XRF and X-Ar analytical skills. UURI provided funding for the SP 77-24 drill core K-Ar ages completed by R. Duncan and described in this chapter.

\section{REFERENCES CITED}

Conrey, R.M., 1985, Volcanic stratigraphy of the Deschutes Formation, Green Ridge to Fly Creek, north-central Oregon: Corvallis, Oreg., Oregon State University, M.S. thesis, 349 p.

-1991. Geology and petrology of the Mt. Jefferson area, High Cascade Range, Oregon: Pullman, Wash., Washington State University, Ph.D. dissertation, $357 \mathrm{p}$. 


\section{Stratigraphy and petrology of the Santiam Pass 77-24 drill core}

Conrey, R.M., and Sherrod, D.R., 1988, Stratigraphy of drill holes and geochemistry of surface rocks, Breitenbush Hot Springs 15-minute quadrangle, Cascade Range, Oregon, in Sherrod, D.R., ed., Geology and geothermal resources the Breitenbush-A.ustin Hot Springs area, Clackamas and Marion Counties, Oregon: Oregon Department of Geology and Mineral Industries Open-File Report 0-88-5, p. 15-29.

Davie, =.I., 1980, The geology and petrology of Three Fingered Jack, a High Cascade volcano in central Oregon: Eugene Oreg., University of Oregon, M.S. thesis, 138 p.

Hill, B.E., 1991, Petrogenesis of compositionally distinct silicic volcanoes in the Three Sisters region of the Oregon Cascade Range: The effects of crustal extension on the development of continental arc silicic magmatism: Corvallis, Oreg., Oregon State University, Ph.D. dissertation, 235 p.

Hughes, S.S., 1983, Petrochemical evolution of the High Cascade volcanic rocks in the Three Sisters region, Oregon: Corvallis, Oreg., Oregon State. University, Ph.D. dissertation, 199p.

-1990, Mafic magmatism and associated tectonism of the central High Cascade Range, Oregon: Journal of Geophysical Research, v. 95, p. 19,623-19,638.

Hughes, S.S. and Taylor, E.M., 1986, Geochemistry, petrology and tectonic implications of centrai High Cascade mafic platform lavas: Geological Society of America Bulletin, v. 97, p. 1,0241,036.

Johnson, R.G., 1982, Brunhes-Matuyama magnetic reversal dated at 790,000 yr B.P. by marine-astronomical cortelaticns: Quaternary Research, v. 17, p. 135-147.

Keith, T.E.C., 1988, Regional patterns of hydrothermal alteration in the Breitenbush-Austin Hot Springs area of the Cascade Range, Oregon, in Sherrod, D.R., ed., Geology and geothermal resources of the Breitenbush-Austin Hot Springs area, Clackamas and Marion Counties, Oregon: Oregon Department of Geology and Mineral Industries Open-File Report 0-88-5, p. 31-45.

Lofgren, G.E., 1980, Experimental studies on the dynamic crystallization of silicate melts, in Hargraves, R.B., ed., Physics of magmatic processes: Princeton, Princeton University Press, p. 487-551.

Mankinen, E.A., and Dalrymple, G.B., 1979, Revised geomagnetic polarity time scale for the interval 0-5 m.y. B.P.: Journal of Geophysical Research, v. 84, p. 615-626.

McBirney, A.R., Sutter, J.F., Naslund, H.R., Sutton, K.G., and White, C.M., 1974, Episodic volcanism in the central Oregon Cascade Range: Geology, v. 2, p. 585-589.

Miyashiro, A., 1974, Volcanic rock series in island ares and active continental margins: American Journal of Science, $v$. 274, p. 321-355.

Priest, G.R., Woller, N.M, Black, G.L., and Evans, S.H., 1983, Overview of the geology of the central Oregon Cascade Range: in Priest, G.R., Vogt, B.F., eds., Geology and geothermal resources of the central Oregon Cascade Range, Oregon Department of Geology and Mineral Industries Special Paper 15, 123 p.

Sakuyama, M., 1981, Petrological study of the Myoko and Kurohime volcanos, Japan: Crystallization sequence and evidence for magma mixing: Journal of Petrology, v. 22, p. 5د3-583.

Steiger, R.H., and Jäger, E., 1977, Subcommission on geochronology: Convention on the use of decay constants in geoand cosmochronology: Earth and Planetary Science Letters, v. 36, p. 359-362. 


\section{Chapter 4}

\section{Thermal results of the Santiam Pass 77-24 drill hole}

by David D. Blackwell, Department of Geological Sciences, Southern Methodist University, Dallas, TX 75275.

\section{ABSTRACT}

The 929-m-deep Santiam Pass 77-24 well in its completed state is characterized by dcwnflow of cold groundwater in the bore that prevents accurate determination of the true rock thermal conditions below $160 \mathrm{~m}$ depth. Average thermal conductivity of the $400-$ to $927-\mathrm{m}$ interval is $1.66 \pm 0.07 \mathrm{~W} / \mathrm{m} / \mathrm{K} . \mathrm{T}$, calculated gradients for the 410-718, 718-920, $912.0-928.0$ and 919.0-928.0-m-depth intervals are $16,52,115.6^{\circ}-0.9$, and $103.6 \pm 2.3^{\circ} \mathrm{C} / \mathrm{km}$, respectively. The gradients in the first two intervals are based on the bottom-hole temperature data. The heat-flow values for the bottnm three intervals of the well are 86,175 and $204 \mathrm{~mW} / \mathrm{m}^{2}$ respectively. These values bracket the regiosial average for the High Cascades of $105 \pm 5 \mathrm{~mW} / \mathrm{m}^{2}$ (Blackwell and others, 1990). The increase of heat flow with depth is inntrolled by regional groundwater flow. The effect of such flow on the thermal field diminishes with depth due to decreases in permeability as the rcuck become progressively more altered. Hot springs and other thermal features along the McKenzie River are probably related to upwardly focused, gravity-driven regional groundwater flow along faults bounding the west side of the High Cascacles graben. The focusing is related to the fault-bounded termination of che relatively more perzneable rocks of the High Cascalies graben against the less permeable rocks of the Western Cascades. The heat flow at the bottom of the well is equal to or higher than the true heat flow, examples from other Cascade Range wells are illustrated to demonstrate the basis for this conclusion. The results demonstrate that heat flow along the Cascade Range axis in an area between active stratovolcanoes is equal to or higher than that along the west edge of the High Cascades as described by Blackwell and others (1982, 1990).

\section{INTRODUCTION}

The Santiam Pass 77-24 well was drilled at 1464 meters elevation ( \& the axis of the Oregon Cascade Range at Santiam Pass. Geothermal gradient and heat flow data from other wells in the region are shown in Figure 4-1. The Santiam Pass well was drilled to obtain temperature gradient, heat flow, hydrologic, and lithologic data that could not be obtained from nearby shallow (100 to $400 \mathrm{~m}$ deep) drill holes. The preliminary results have already bees summarized by Fill and others (1991a; this volume).

The Santiam Pass well was drilled during August and September of 1990. Bottom bole temperatures were measured with maximum reading thermometers every 20-30 meters during drilling. A caliper log was run prior to completion, and natural gamma-ray and tempera.ure logs were run on September 19, 19\%, after completion. A second 


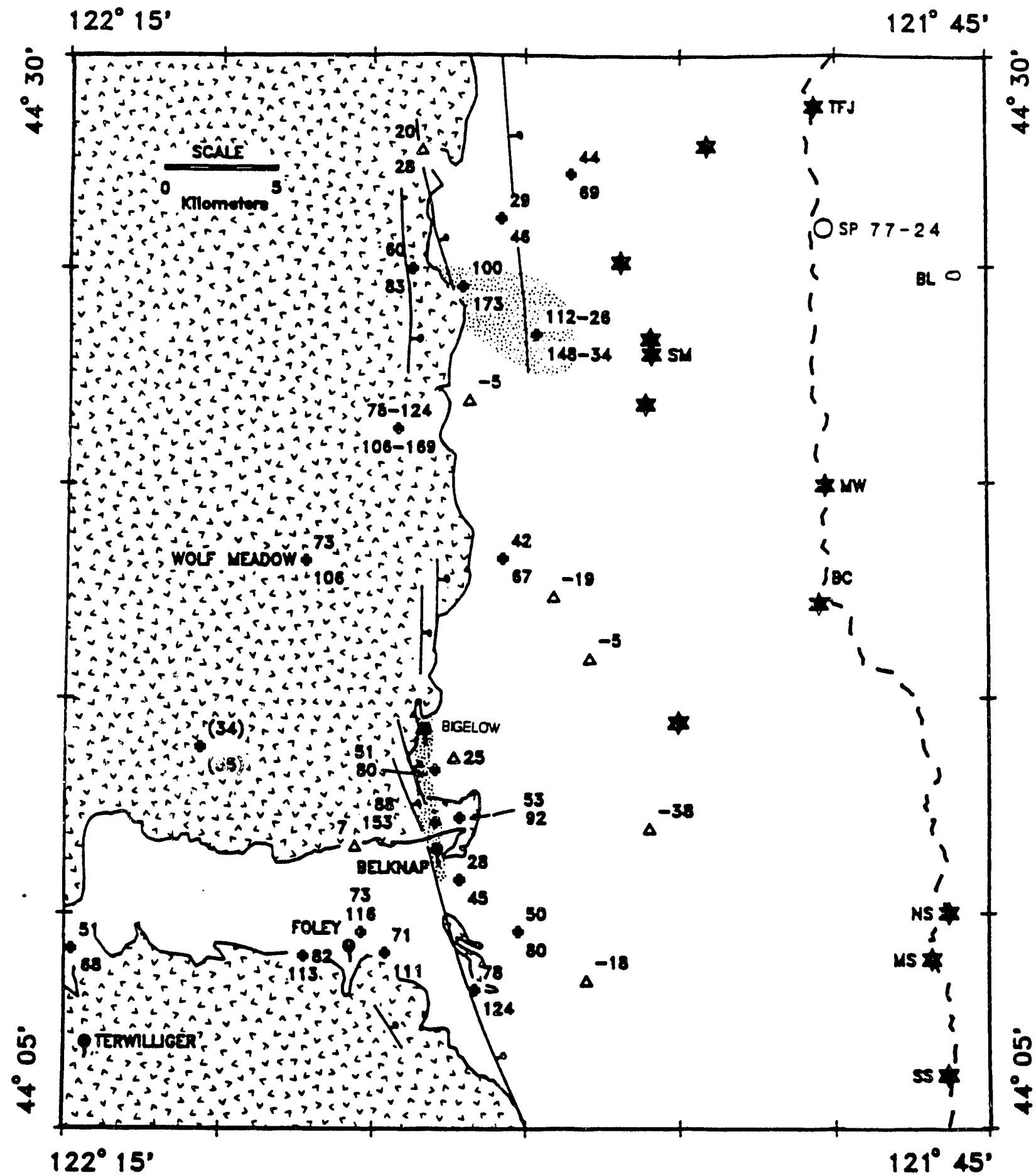

Figure 4-1. Location map of the Santiam Puss area. Geothermal gradient $\left({ }^{\circ} \mathrm{C} / \mathrm{km}\right.$, upper value) and heat flow values $\left(\mathrm{mW} / \mathrm{m}^{2}\right.$, lower value) are shown. Drill holes in Holocene rocks are marked by open triangles. Major volcanic centers are shown as star;; Cascade Range crest is dashed line. Major westedge faults of High Cascades graben are shown. Rocks older than Quatemary (from Black and others, 1987; Priest and ochers, 1988) shown by caret pattem. Stippled patten marks heat flow anomalies. Abbreviations are TFJ, Three Fingered Jack; BL, Blue Lake; MW, Mount Washington; BC, Bellonap Crater, NS, MS, SS; North, Middle and South Sister, SM, Sand Mountain. Modified from Figure 5 in Blackwell and others (1990). Santiam Pass site is shown as SP 77-24. 
temperature log was run on September 27, 1990, and a final temperature log was run on September 3, 1991. The equilibrated bottom-hole temperature is $25.06^{\circ} \mathrm{C}$ at a depth of $928.4 \mathrm{~m}$, with apparent temperature gradients of $50-60^{\circ} \mathrm{C} / \mathrm{km}$ from $700-900 \mathrm{~m}$ and between 103 and $116^{\circ} \mathrm{C} / \mathrm{km}$ below $910 \mathrm{~m}$.

\section{REGIONAL SETTING}

The geology of the study area is shown in very simplified form in Figure 41 (from Priest and others, 1988; Black and others, 1987), and discussed in detail by Hill and Priest (Chapter 2). The western part of the area is underlain by Pliocene and older volcanic rocks, whereas the eastern part of the area is covered by Quaternary volcanic rocks. The well site is along the topographic axis of the Cascade Range between the Three Sisters and Mt. Jefferson stratovolcanoes. The nearest large Quaternary centers are the Three Finger Jack and Mount Washington volcanoes. The study area was the site of extensive basaltic volcanism about 3000 years ago and the Sand Mountain chain of centers (SM on Figure 41) dates from that episode of volcanism. Most of the area west of the crest and north of $44^{\circ} 10^{\prime} \mathrm{N}$ is covered by these 3000 year-old basalt flows (Taylor, 1968). A series of down-to-the-east normal faults representing the west side of the High Cascades graben divides the High Cascades from the Western Cascades.

There are extensive thermal data available in the area to the west along the McKenzie River drainage (Blackwell and others, 1982, 1990, Cox and others, 1981). The thermal conditions of the area there have been discussed by Blackwell and others (1990). Locations of drill holes are shown in Figure 41 along with geothermal gradients and heat flow values. This area has a complex thermal pattern. Heat flow in $150 \mathrm{~m}$ holes is zero to negative on the east side, increases to quite high values in the center of the map $\left(\geq 100 \mathrm{~mW} / \mathrm{m}^{2}\right)$, and then decreases west of the map area to values of less than 60 $\mathrm{mW} / \mathrm{m}^{2}$. This same pattern is observed eisewhere in the Cascade Range (Blackwell and others, 1982, 1990).

Temperature-depth curves for several of the shallow wells in the area are shown in Figure 4-2. These temperature-depth curves can be related to the topographic and geologic setting of the wells. The wells in the Holocene basalt (Figure 42, wells SA3, SA10, SA13, SA14, SA17) have isothermal to negative slopes on the temperature-depth plots. These types of temperature-depth curves are due to the rapid flow, both vertically and horizontally, of ground water in the extremely permeable young basalt. The series of holes with low but positive gradients (Figure 4-2, wells SA5, SA7, SA12, and SA16) were drilled in Quaternary volcanic rocks that make up part of the Cascades graben fill. The gradients in these wells are generally below the regional gradient of $65^{\circ} \mathrm{C} / \mathrm{km}$. However, in one deeper hole (EWEB-CL, Figure 4 4) the geothermal gradients range from $112^{\circ} \mathrm{C} / \mathrm{km}(15-200 \mathrm{~m})$ to $21^{\circ} \mathrm{C} / \mathrm{km}(485$ to $555 \mathrm{~m})$. The shape of the temperature-depth curve clearly indicates lateral flow of warm water in a confined aquifer through an area otherwise characterized by a lower-than-background temperature and heat flow related to groundwater recharge (Blackwell and others, 1982). A 150 -m-deep well $4 \mathrm{~km}$ to the northwest of EWEB-CL has a gradient of $100^{\circ} \mathrm{C} / \mathrm{km}$, the highest gradient along the boundary province not near a known geothermal anomaly. Consequently, in the northern part of the map (stippled area on Figure 4-1) there is probably lateral flow of warm water at relatively shallow depth (Blackwell and others, 1990).

The gradients for wells S5 and SA11 (Figure 4-2) are near the expected regional value of $65 \pm 5^{\circ} \mathrm{C} / \mathrm{km}$. These two wells are sited west of the graben in pre-Quaternary rocks where the permeabilities are low and fluid flow is confined to 


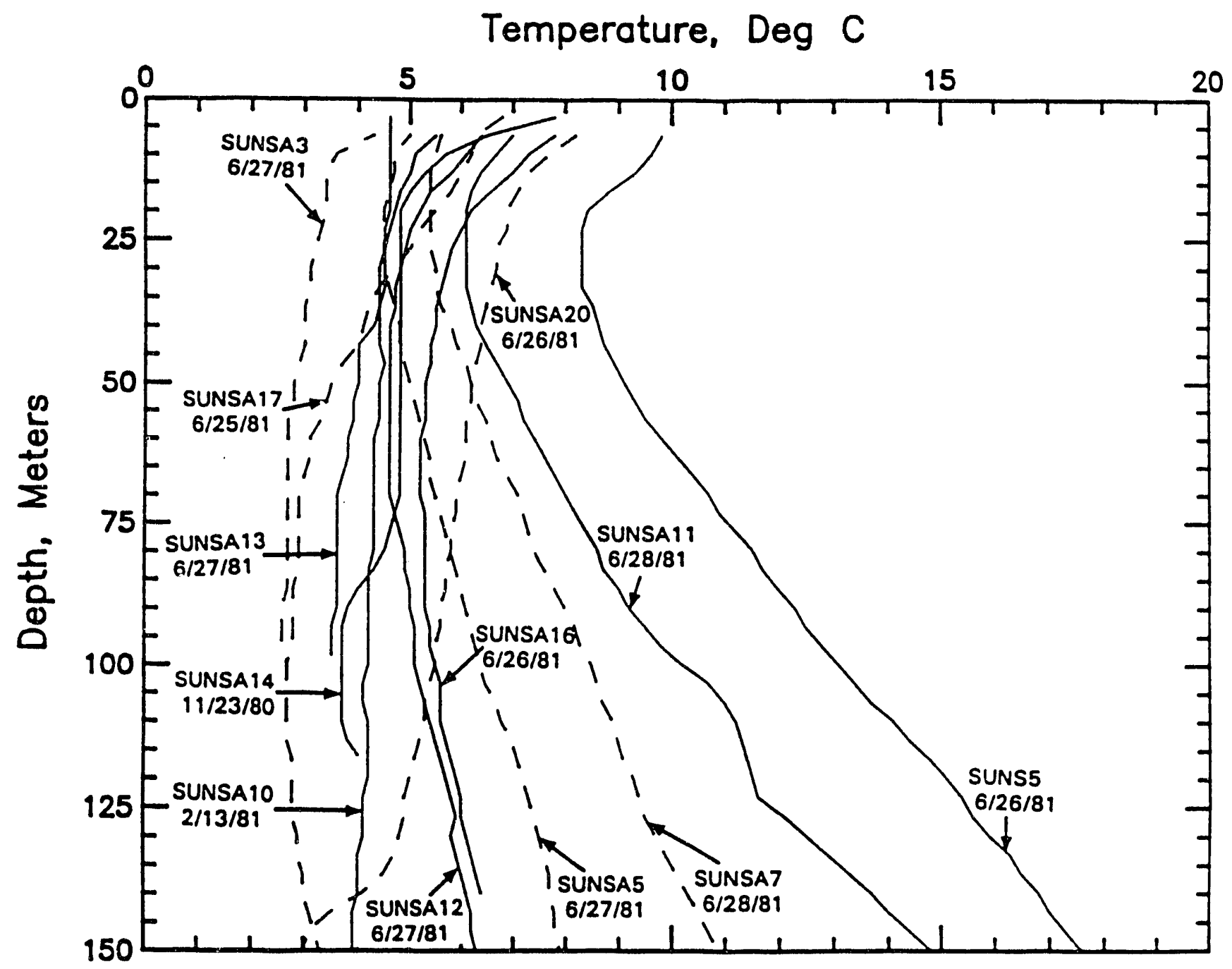

Figure 42. Temperature depth plots for Sunedco $150 \mathrm{~m}$ deep holes. Temperatures were measured every $5 \mathrm{~m}$. Numbers are hole identifications.

discrete aquifers and fault zones. Other shallow wells that penetrate the older rocks also have typical gradients of $65 \pm 5^{\circ} \mathrm{C} / \mathrm{km}$ in this area (i.e. Wolf Meadow and the holes near Belknap and Foley Springs from Blackwell and others, 1982, 1990). West of Figure 4-1 the gradients decrease to values of 25 to $35^{\circ} \mathrm{C} / \mathrm{km}$, which are typical of the Pacific coastal provinces (Blackwell and others, 1982).

There are four hot springs in the area; Bigelow, Belknap, Foley, and Terwilliger. The spring temperatures are in the range of $46^{\circ} \mathrm{C}$ (Terwilligez) to $79^{\circ} \mathrm{C}$ (Foley) and the reservoir temperatures based on geochemical thermometers are estimated to be between 113 and $150^{\circ} \mathrm{C}$. Ingebritsen and others (1991) estimated a total flow of $36 \pm 5 \mathrm{l} / \mathrm{s}$ from the springs and a total convective component of $24,000 \mathrm{~kJ} / \mathrm{s}$, which is equivalent to the estimated conductive heat loss from an area of $240 \mathrm{~km}^{2}$ in the High Cascades thermal province. 


\section{WELL 77.24 THERMAL RESULTS}

\section{Temperatures}

The three temperature-depth curves recorded for the well are shown in Figure 43. Between the temperature log immediately following completion of drilling on September 19, 1990, and the log of September 27, 1990, the temperatures in the hole cooled about 1 to $1.5^{\circ} \mathrm{C}$ except in the depth range 160 to $180 \mathrm{~m}$ and below $910 \mathrm{~m}$. By September 3, 1991 the well had cooled an additional 1.5 to $2^{\circ} \mathrm{C}$ in the upper part and up to $6^{\circ} \mathrm{C}$ at about $900 \mathrm{~m}$. This cooling is the response of the well to long-term flow down the well bore. The shallow zone that shows little drilling effect on the first log (at about $160 \mathrm{~m}$ ) is a zone of active groundwater flow, and the flow of the water past the hole has caused the hole to recover more rapidly than the areas of the hole not so affected. The volume and rapidity of natural groundwater flow in the 160 m-depth aquifer is emphasized by the fact that most drilling fluid was lost into this zone with virtually no temperature effect.

\section{TEMPERATURE, DEG C}

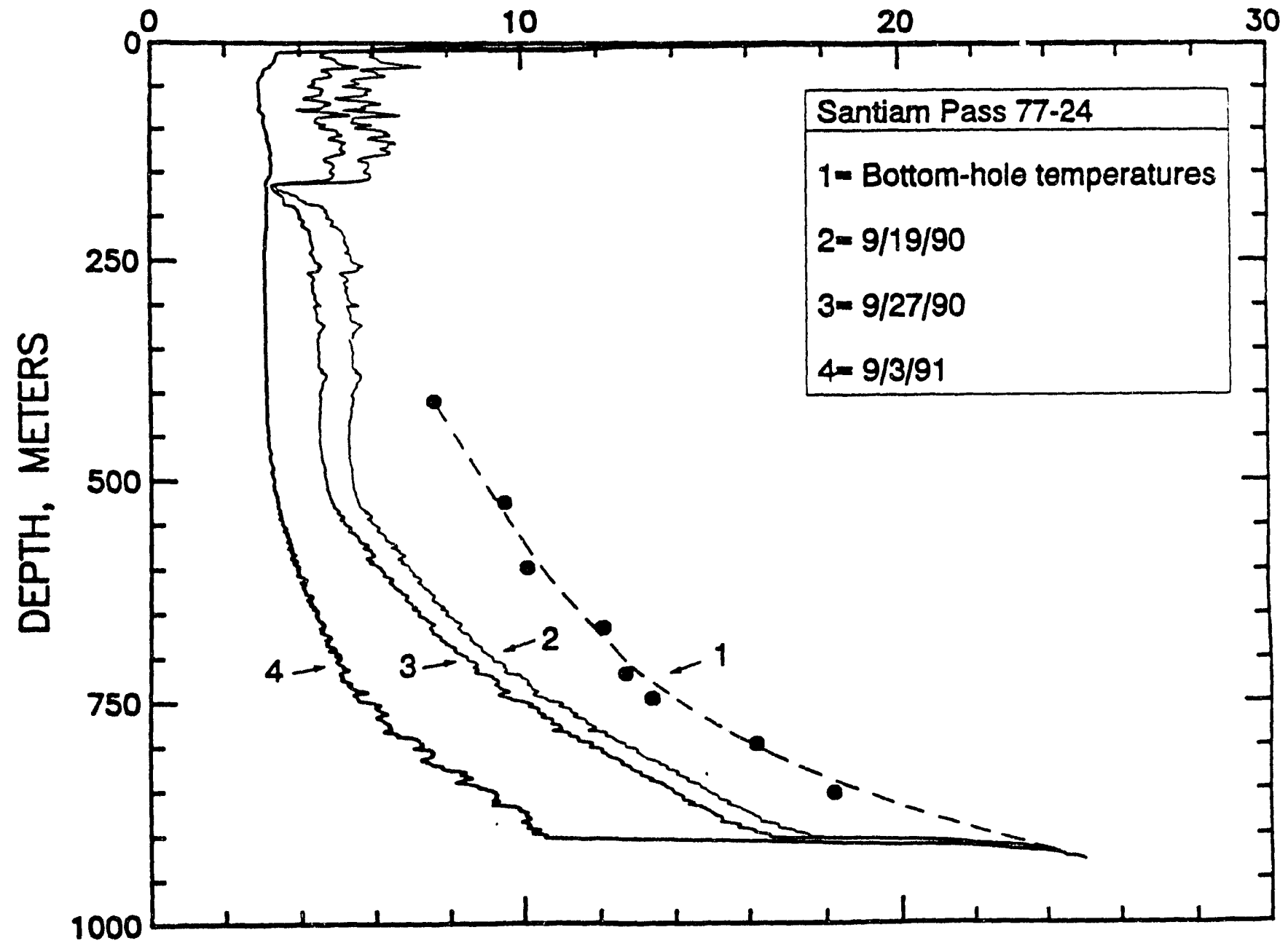

Figure 4-3. Temperature-depth curves for the three loggings of the Santiam Pass 77-24 well. The dashed line connects bottom-hole temperature measurements made as drilling proceeded. 
Ground water is also flowing into the well. As a consequence the final curve has temperatures above $500 \mathrm{~m}$ that reflect only the temperature of the groundwater where the water flow actually enters the well, and thus the curve is nearly isothermal from the surface to $500 \mathrm{~m}$. The geothermal gradient in the well bore from 500 to $900 \mathrm{~m}$ increases from about 20 to about $60^{\circ} \mathrm{C} / \mathrm{km}$ in the first $\log$ and from 10 to about $35^{\circ} \mathrm{C} / \mathrm{km}$ in the final $\log$. There is a step in the temperatures of about $6^{\circ} \mathrm{C}$ at $900 \mathrm{~m}$ and the gradient is $116^{\circ} \mathrm{C} / \mathrm{km}$ below 900 in the first $\log$, and there is a step of $12{ }^{\circ} \mathrm{C}$ and the gradient is $103.6 \pm 2.3{ }^{\circ} \mathrm{C} / \mathrm{km}$ between 919.0 and $928.0 \mathrm{~m}$ in the final log. An average gradient of $115.8 \pm 0.9{ }^{\circ} \mathrm{C} / \mathrm{km}$ from $912.0 \mathrm{~m}$ to $928.0 \mathrm{~m}$ is calculated for the last two temperature logs.

The undisturbed, or rock temperatures, in the well between 170 and $900 \mathrm{~m}$ are remarkably differeat than implied by the temperature logs. Bottom-hole temperatures (BHT) were measured at several depths during the process of drilling. Temperature measurements were made over periods of 20 minutes to 1 hour, and estimated equilibrium temperatures calculated by extrapolation. These estimated equilibrium temperatures are plotted on Figure 43. The BHT's show considerably higher temperatures in the 500-to $900-\mathrm{m}$-depth range (about 5 to $14^{\circ} \mathrm{C}$ higher) than the highest temperatures measured following drilling. The estimated rock temperature-depth curve is shown by the dashed line. Water enters into the hole at $160 \mathrm{~m}$ depth, the point of persistent loss of drilling fluid during the drilling process. This water flows down the hole, cooling the hole by about 6 to $14^{\circ} \mathrm{C}$, and exits at $900 \mathrm{~m}$, causing the observed step. Numerous unsuccessful attempts were made during drilling to plug the extensive zones of lost circulation below $160 \mathrm{~m}$. However, high viscosity completion mud was successfully circulated in the hole for 2.5 hours before the $2^{n}$ conductor pipe was set. It is now apparent that groundwater flow was sufficent to dilute and remove the completion mud between 160 and $900 \mathrm{~m}$. The position of the well at the topographic divide also makes the possibility of downflow very likely, due to large differences in piezometric head in different aquifers. The shape of the temperature-depth curve inferred from the BHT data implies that the undisturbed gradient in the hole might be on the order of $15^{\circ} \mathrm{C} / \mathrm{km}$ between 160 and $750 \mathrm{~m}$, about 50 to $60^{\circ} \mathrm{C} / \mathrm{km}$ between 750 and $850 \mathrm{~m}$, and about 100 to $120^{\circ} \mathrm{C} / \mathrm{km}$ at the bottom of the hole. The 50 to $60^{\circ} \mathrm{C} / \mathrm{km}$ gradient is slightly below regional for the area while the gradient of 100 to $120^{\circ} \mathrm{C} / \mathrm{km}$ is slightly to significantly above regional value.

\section{Thermal Conductivity}

The thermal conductivity of 46 samples of the core from the well was measured using the divided bar technique (see Blackwell and Spafford, 1987). The measured thermal conductivity, porosity, and density values are listed in Table 4-1. Thermal conductivity values are quite uniform and variations are primarily a function of the porosity of the samples. The ash layers have the lowest thermal conductivity values, whereas there is little difference in the thermal conductivity of the basalt and andesite flows. Average thermal conductivity of the $400-$ to $927-\mathrm{m}$ interval is $1.66 \pm 0.07 \mathrm{~W} / \mathrm{m} / \mathrm{K}$ These values are typical of other areas in the Cascade Range. 
Table 41. Thermal conductivity measurements for Santiam Pass core samples.

\begin{tabular}{|c|c|c|c|}
\hline $\begin{array}{l}\text { Depth } \\
\text { meters }\end{array}$ & $\begin{array}{l}\text { Porosity } \\
\text { percent }\end{array}$ & $\begin{array}{l}\text { Dry Density } \\
\text { gm/cc }\end{array}$ & $\begin{array}{l}\text { Thermal conductivity } \\
\mathrm{W} / \mathrm{m} / \mathrm{K}\end{array}$ \\
\hline 143.6 & 3.5 & 2.73 & 1.62 \\
\hline 171.6 & 4.1 & 2.70 & 1.78 \\
\hline 188.4 & 3.7 & 2.69 & 1.65 \\
\hline 194.5 & 4.5 & 2.66 & 1.67 \\
\hline 201.2 & 3.8 & 2.74 & 1.68 \\
\hline 215.8 & 2.9 & 2.69 & 1.82 \\
\hline 223.4 & 3.8 & 2.67 & 1.85 \\
\hline 232.9 & 11.6 & 2.36 & 1.35 \\
\hline 249.0 & 3.2 & 2.71 & 1.77 \\
\hline 256.6 & 3.0 & 2.72 & 1.73 \\
\hline 271.0 & 4.4 & 2.72 & 1.65 \\
\hline 284.1 & 18.4 & 2.23 & 1.34 \\
\hline 295.0 & 4.5 & 2.68 & 1.70 \\
\hline 304.5 & 15.1 & 2.26 & 1.35 \\
\hline 317.9 & $4.6^{\circ}$ & 2.64 & 1.57 \\
\hline 334.1 & 5.5 & 2.65 & 1.68 \\
\hline 343.5 & 3.1 & 2.60 & 1.56 \\
\hline 356.6 & 3.3 & 2.69 & 1.76 \\
\hline 363.0 & 3.8 & 2.72 & 1.77 \\
\hline 378.9 & 3.6 & 2.74 & 1.84 \\
\hline 393.5 & 3.3 & 2.69 & 1.75 \\
\hline 401.1 & 6.6 & 2.59 & 1.69 \\
\hline 413.9 & 4.1 & 2.70 & 1.73 \\
\hline 431.6 & 4.1 & 2.68 & 1.71 \\
\hline 465.4 & 5.4 & 2.63 & 1.80 \\
\hline 484.9 & 3.9 & 2.71 & 1.71 \\
\hline 492.6 & 2.1 & 2.73 & 1.78 \\
\hline 501.7 & 2.4 & 2.73 & 1.84 \\
\hline 522.1 & 11.3 & 2.45 & 1.46 \\
\hline 543.5 & 4.0 & 2.67 & 1.65 \\
\hline 554.1 & 3.5 & 2.69 & 1.74 \\
\hline 573.9 & 6.9 & 2.53 & 1.57 \\
\hline 595.6 & 8.2 & 2.58 & 1.58 \\
\hline 613.6 & 10.1 & 2.50 & 1.49 \\
\hline 655.0 & 4.5 & 2.66 & 1.79 \\
\hline 676.0 & 17.1 & 2.16 & 1.43 \\
\hline 701.6 & 10.4 & 2.16 & 1.58 \\
\hline 716.0 & 14.1 & 2.27 & 1.38 \\
\hline 719.3 & 5.8 & 2.66 & 1.72 \\
\hline 721.8 & 21.2 & 2.01 & 1.31 \\
\hline 734.6 & 12.0 & 2.01 & 1.01 \\
\hline 771.1 & 5.0 & 2.67 & 1.64 \\
\hline 796.7 & 2.8 & 2.78 & 1.82 \\
\hline 822.0 & 1.9 & 2.76 & 1.89 \\
\hline 873.6 & 25.8 & 2.10 & 1.46 \\
\hline 882.1 & 4.2 & 2.74 & 1.85 \\
\hline 907.1 & 1.9 & 2.80 & 1.82 \\
\hline 927.2 & 3.4 & 2.69 & 1.69 \\
\hline
\end{tabular}




\section{Heat Flow}

Calculated gradients for the 410-718, 718-920, 912.0-928.0 and 919.0-928.0-m-depth intervals are 16, 52, 115.8 \pm 0.9 and $103.6 \pm 2.3^{\circ} \mathrm{C} / \mathrm{km}$, respectively. The gradients in the first two intervals are based on BHT data. Heat-flow values for the bottom three intervals of the well are 86,204 , and $175 \mathrm{~mW} / \mathrm{m}^{2}$ respectively. These values bracket the regional average for the High Cascades of $105 \pm 5 \mathrm{~mW} / \mathrm{m}^{2}$ (Blackwell and others, 1990). The average gradient in the depth range 900 to $920 \mathrm{~m}$ is about $120^{\circ} \mathrm{C} / \mathrm{km}$. The minimum gradient in the bottom third of the hole is $50^{\circ} \mathrm{C} / \mathrm{km}$. The high gradient in the bottom zone may or may not be the best to use in further extrapolation to depth.

Two illustrative examples from the Oregon Cascades are shown in Figure 4-4. One hole is from the Mt Hood area (USGS-PUC) and one hole is about $25 \mathrm{~km}$ northwest of the Santiam Pass hole (EWEB-2). The gradient and heat flow values for these wells are shown and discussed by Blackwell and others (1982, Figure 6; see also Stecle anil others, 1982). In the EWEB-2 hole (elevation $1195 \mathrm{~m}$ ), the regional gradient of $65^{\circ} \mathrm{C} / \mathrm{km}$ starts immediately below the groundwater effect at 250-m depth. In the USGS-PUC hole the regional gradient is reached at about $400 \mathrm{~m}$, below about $250 \mathrm{~m}$ of higher-than-regional gradient and $150 \mathrm{~m}$ of low gradient in the zone of active water flow. So the gradient below the depth of active groundwater flow can be higher than or equal to the gradient characteristic of greater depths.

The nearest hole to the Santiam Pass well is about $12 \mathrm{~km}$ to the west at the EWEB-1 (EWEB 78-32 on Plate 1) site near Clear Lake at an elevation of $975 \mathrm{~m}$. The Santiam Pass bole is at $1463 \mathrm{~m}$ so the difference in elevation is about $500 \mathrm{~m}$. The temperature-depth data are shown in Figure $4-4$ for comparison. The bottom-hole temperatures are similar at equal elevations. Both wells appear to be in areas of recharge or rapid lateral flow of groundwater because the temperatures and the gradients are below regional to depths of 400 to $500 \mathrm{~m}$.

However, the pattern of fluid flow is not simple because the warm temperatures at $200 \mathrm{~m}$ in EWEB-1 (28० $\mathrm{C})$ are evidence of lateral flow of warm water from as yet unlocated direction past the well site, as described by Blackwell and others (1982; compare to the temperature effects of lateral flow of warm water modeled by Ziagos and Blackwell, 1986).

\section{ELECTRICAL RESISTIVITY}

In the Santiam Pass area there has been extensive exploration using various techniques that measure the subsurface electrical resistivity. A survey using the roving dipole technique was carried out by Pritchard and Meidav (1975) with some followup studies by Electrodyne Surveys (1979). These studies focused in and around the valley of the McKenzie River. Argonaut Enterprises (1982) carried out a magnetotelluric survey along a east-west profile more or less centered on Foley Spring. In 1989 the USGS (Dallas Stanley, written commun., 1989) carried out a 7 point audio-magnetotelluric sounding survey in the vicinity of the Santiam Pass well site. In view of the interest in the comparison of thermal and electrical exploration techniques, the results of the electrical studies will be briefly summarized here.

An apparent conductance map from the roving dipole study of Pritchard and Mvidav (1975) is shown in Figure 4-5. Figure 4-5 covers the same area as Figure 4-1 so the two data sets can be spatially compared. The positions of the dipole sources are the heavy straight lines and the recording points are the small dots. There were three source positions, two in the north and one in the south. The apparent resistivity values range from about 1 to over 200 D.m. The largest low resistivity region extends for at least $7 \mathrm{~km}$ in a SW-NE direction just northwest of Sand Mountain (SM in Fiqure 4-5), 


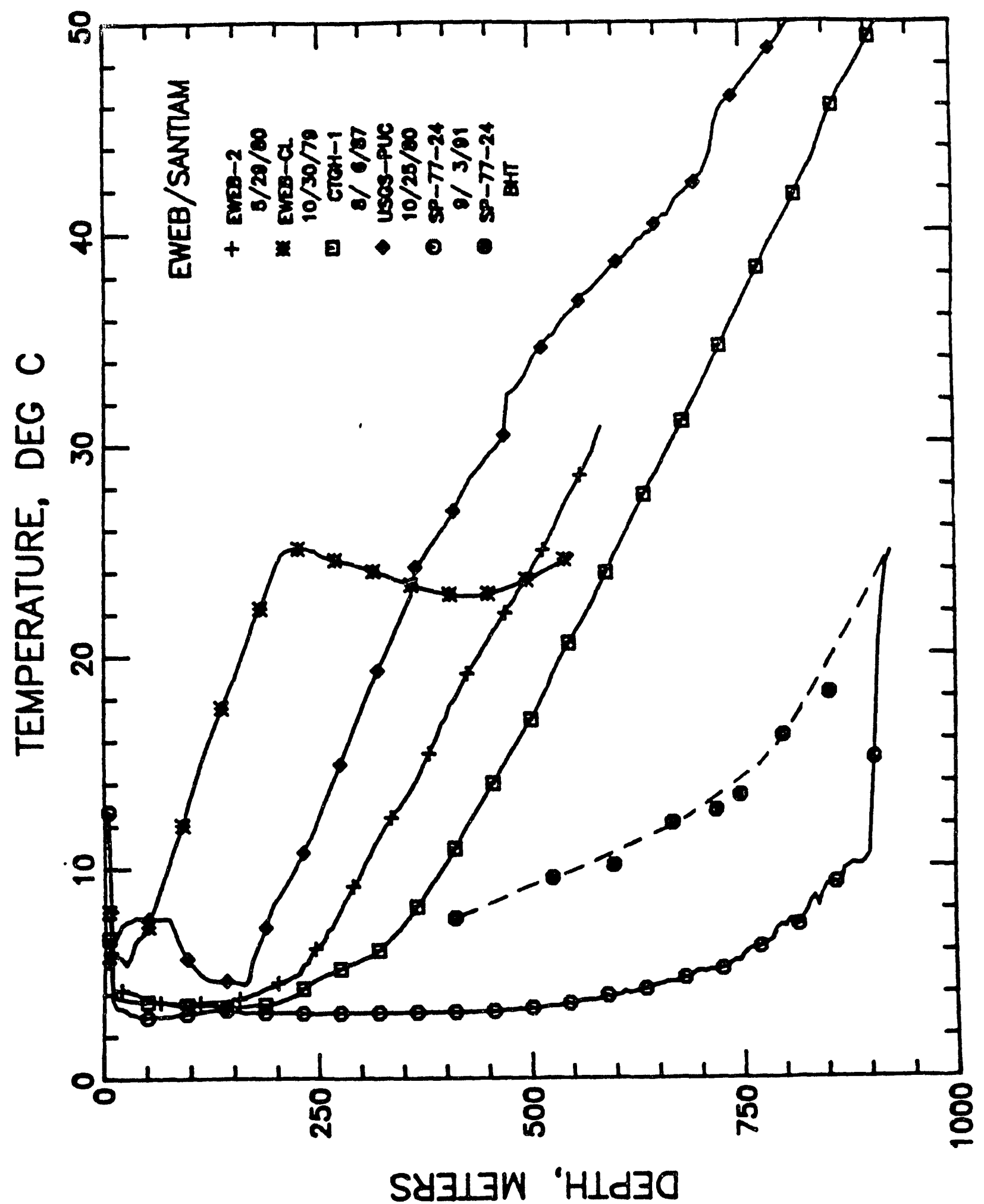

Figure 44. Comparison of temperature-depth curves in the Santiam Pass $77-24$ well and some other High Cascade Range wells. Temperature symbols mark every 9 th measured temperature point. 


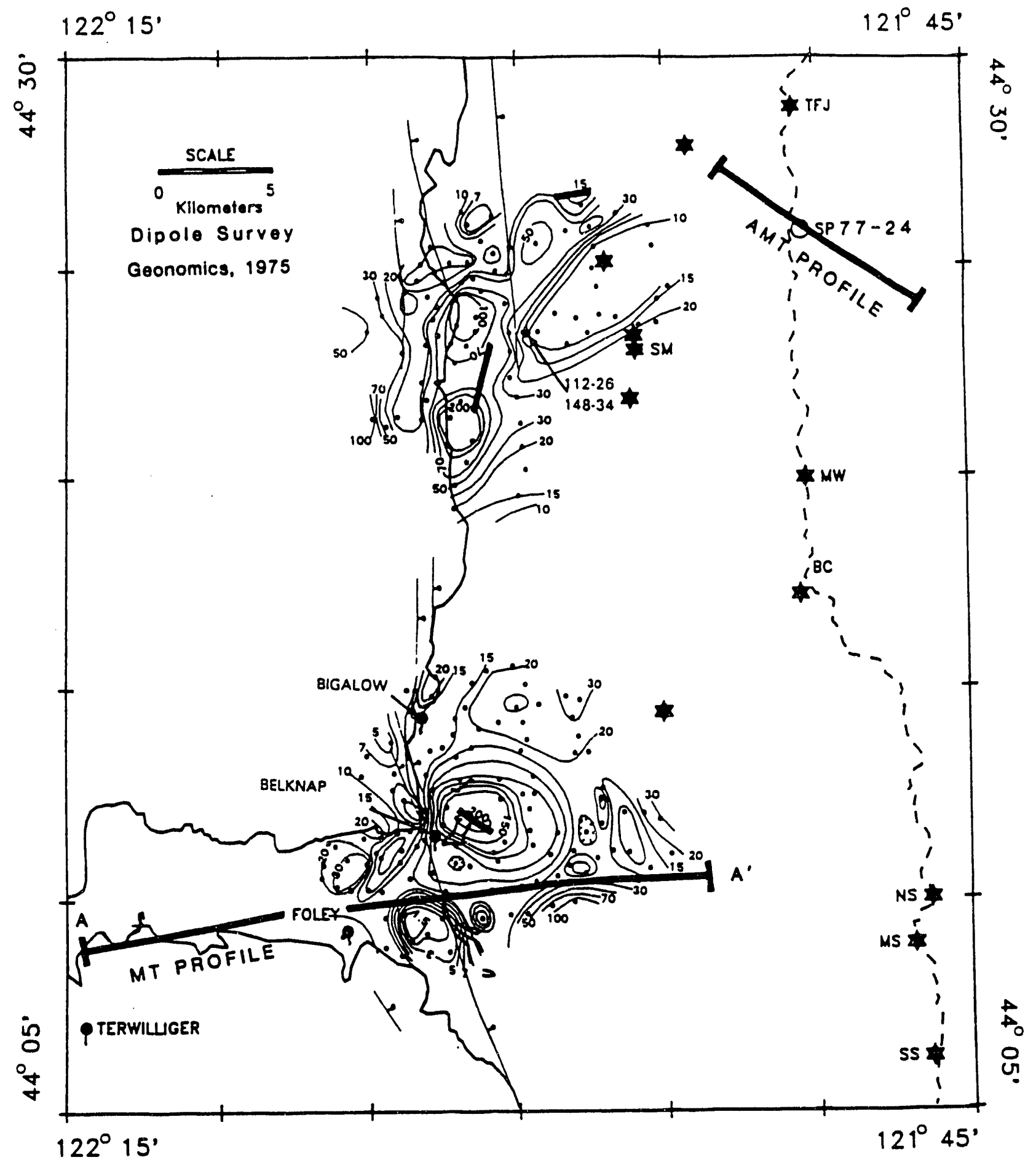

Figure 45. Contours of equal electrical resistivity from dipole soundings (Pritchard and Meidav, 1975). Location of the AMT sounding profile from Stanley (written commun., 1989) is shown in the northeast part of the map. Location of the MT section from Argonaut Enterprises (1982) is shown (section A-A') in the south part of the map. Geographic abbreviations are the same as in Figure 41. 
which is an approximately 3000-year-old cinder cone. This low resistivity zone was tested for a positive thermal anomaly by the EWEB-1 well shown in Figure 44. The shallow thermal gradients are high but the deep temperatures are disappointingly low. The low resistivity region does not underlie the shallow well with high gradient northwest of the EWEB-1 well (see Figure 4-1). Because the roving dipole technique samples the subsurface in a complicated way, it is not easy to associate particular anomalies with specific depths. Thus the cause of the low resistivity region remains enigmatic.

The CTGH-1 well ( 1 'jure 4-4) was also drilled in a low resistivity anomaly (J. Iovenitti, oral commun., 1986), north of the present study area. CTGH-1 has a high but regional temperature gradient of about $80^{\circ} \mathrm{C} / \mathrm{km}$ (Blackwell and Baker, 1988b) and the rocks below $400 \mathrm{~m}$ have undergone pervasive low-temperature ( $<100^{\circ} \mathrm{C}$, Bargar, 1988 ) alteration. The best interpretation of the magnetotelluric results seems to be that the low resistivities are due to the alteration rather than due to a local geothermal anomaly.

An east-west profile from the MT survey of Argonaut Enterprises (1982) is shown in Figure 46. The location of the profile is shown on Figure 4-5. The results of this profile are typical of the other sites studied. The section shows three layers referred to on the section as "resistive", "conductive", and "resistive" in order of depth occurrence. Along the east side of the section the bottom of the upper resistive layer (with resistivities of 50 to $100 \mathrm{\Omega} \cdot \mathrm{m}$ and correlated with Quaternary basalts) occurs at an elevation of about 500 to $600 \mathrm{~m}$, or at typical depths of 400 to $600 \mathrm{~m}$ below the surface. The conductive layer (about 1 to $5 \Omega \cdot \mathrm{m}$ ) crops out along Horse Creek and along the west side of the section in the McKenzie River valley. Beneath the conductive layer the resistivity increases again to values of greater than $100 \Omega \cdot m$ at typical depths of greater than 1 to $1.2 \mathrm{~km}$ (about sea level in elevation). One interpretation of the conductive layer is that it represents a warm aquifer carrying thermal water from the Cascades axis to the west analogous to the aquifer at Breitenbush Hot Springs described by Blackwell and Baker (1988a, 1988b). The evidence of lateral flow at the north part

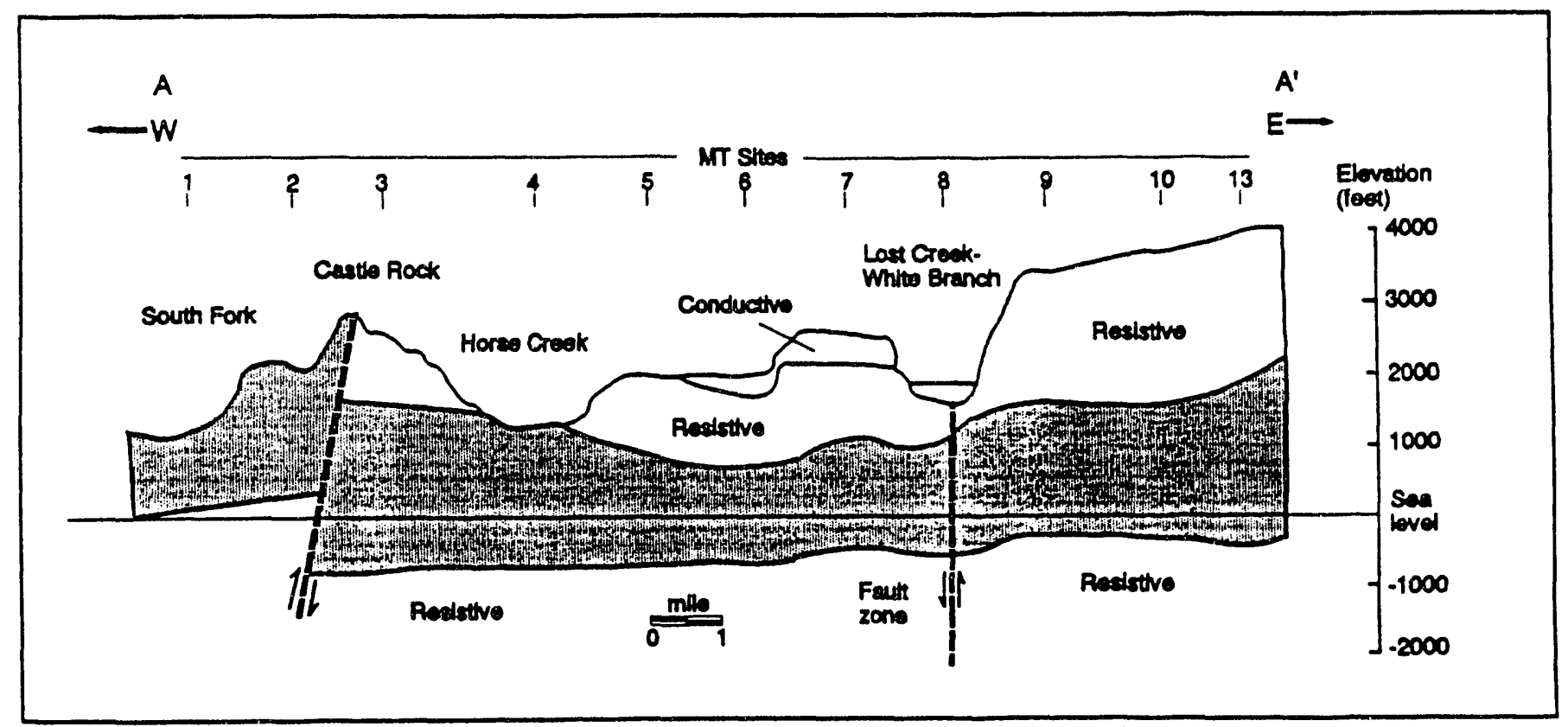

Figure 46. MT profile electrical resistivity interpretation (Argonaut Enterprises, 1982). The location of the cross section in shown on Figure 45. 


\section{Blackwell}

of the map area lends credence to this interpretation. An alternative interpretation is that the conductive region corresponds to the areas of alteration in the older and/or more deeply buried rocks and has no direct thermal implication. This interpretation is favored based on the occurrence of the hot springs along steeply dipping faults and the general coincidence of the areas where the low resistivity area comes to the surface with outcrops of pre-Quaternary rocks. The higher resistivity regions at greatest depth may be areas of higher temperature rock alteration where clays and zeolites are replaced by more resistive mineralogy.

A series of audio-magnetotelluric (AMT) electrical soundings were carried out by Herbert Pierce of the USGS (Dallas Stanley, written commun., 1989). The locations of these soundings are shown on Figure 4-5. Additional data have been collected by Livelybrooks and others (1989). These results in the vicinity of the Santiam Pass well are consistent with a several hundred-meter-thick layer of rocks with high electrical resistivity underlain by rocks with a much lower resistivity. This configuration is similar to that seen on the MT profile along the McKenzie River. The depths to the low resistivity appear to be somewhat deeper along the Santiam Pass section, in agreement with the relatively low degree of alteration seen in the drill core.

The interpretation is that in general rocks in the Cascade Range that have been subjected to alteration due to either localized hydrothermal activity or regional diagenetic low-grade metamorphism have low resistivity. Thus, in general, areas of low electrical resistivity correspond to areas of generally low permeability, altered volcanic rocks while areas of high electrical resistivity generally correspond to regions of high permeability, unaltered volcanic rocks. A similar situation has been described in detail at Newberry volcano by Wright and Nielsen (1986).

\section{GEOTHERMAL MODEL}

The effect of alteration on permeability and consequently on heat transport by groundwater flow in the volcanic rocks of the Cascade Range has been previously described by Blackwell and others (1982, 1990). They concluded from the drilling evidence that the shallow hydrologic properties and shallow thermal conditions were related to the degree of rock alteration, which coincides to some extent with maximum depth of burial (maximum temperature reached) of the rocks. The degree of success of obtaining gradients in 150-m-deep holes in the Cascade Range (Blackwell and others, 1982) is a testimony to the careful selection of sites based on age and alteration criteria by the DOGAMI geologists in charge of siting the wells. Geothermal exploration studies, which have been more constrained by a need to have data from certain locations that are generally higher in elevation, have had significantly lower rates of success using 150-m-deep exploration holes.

The extensive fluid flow at shallow depths has been referred to as the "rain curtain" and discussed in detail for two Newberry Volcano holes by Swanberg and Combs (1986) and Swanberg and others (1988). Temperatures from all deep holes (over $1 \mathrm{~km}$ depth) in the Cascade Range except the Santiam Pass 77-24 (excluding data from the Newberry volcano which show similar characteristics) were shown in Figure 4 of Blackwell and others (1990, see also Figure 6 in Blackwell and others, 1982). In addition to the EWEB-2 and USGS-PUC wells another example of the temperature-depth behavior in the High Cascades is the 1.4-km-deep CTGH-1 hole drilled near the Cascade Range crest north of Mount Jefferson. The CTGH-1 well has a heat flow of $110 \mathrm{~mW} / \mathrm{m}^{2}$. Its thermal characteristics have been discussed in detail by Blackwell 
and Steele (1987) and Blackwell and Baker (1988a, 1988b). The increase in gradient to regional values occurs between 400 and $500 \mathrm{~m}$, and is associated with the initial occurrence of alteration that has taken place at temperatures between 50 and $100^{\circ} \mathrm{C}$ (Bargar, 1988). The alteration has presumedly lowered the electrical resistivity of the volcanic rocks. In all these cases the gradients and heat flow values in the deep holes below the groundwater flow zones are consistent with the predictions based on $150 \mathrm{~m}$ holes nearby or on regional considerations.

Blackwos and Steele (1987) described temperature-depth data from a well at the edge of Crater Lake Park $(\mathrm{CE}-\mathrm{CL}-1)$ in an area of no surface geothermal manifestations. Hole CE-CL-1 has a high gradient (about $250^{\circ} \mathrm{C} / \mathrm{km}$ ). The results from $\mathrm{CE}-\mathrm{CL}-1$ illustrate that if the surface rocks are altered, representative gradients may be obtained at much shallower depths ( $<200$ to $400 \mathrm{~m}$ ) than those required in areas of unaltered volcanic rocks. Thus in the Oregon Cascade Range low electrical resistivity values can be associated with alteration of the volcanic rock to clay and zeolites and may not be associated with contemporary high temperature regions.

The deep drilling results show that isothermal sections occur to depths ranging up to $500 \mathrm{~m}$ at various sites within the High Cascades although typical values are less than $400 \mathrm{~m}$. I also conclude that, on the basis of present data, consistently high geothermal gradients (in excess of $50^{\circ} \mathrm{C} / \mathrm{km}$ ) are observed below the zone of rapid groundwater circulation. The only exception at present is the EWEB-1 hole near Santiam Junction. Furthermore, there is often an abrupt depth transition between rocks which have high permeability and rapid fluid through-flow (near isothermal temperature-depth curves) and rocks where the average permeability is quite low and fluid flow is suppressed. The 50-200 m transition zones from low to regional values of geothermal gradient typical of the deep holes is evidence that large scale flow at depth is unlikely to occur generally except along particularly favorable stratigraphic regions or along fractures or fault zones.

However, the geothermal model for the Santiam Pass area must involve significant, general, fluid flow at depth in the Quaternary rocks of the High Cascades graben (the eastern half of Figure 41 ). In some cases the flow is confined to discrete aquifers (as in the top of well EWEB-1) and in other cases there must be general porous-media flow. In all probability most of the flow systems terminate against the low-permeability pre-Quaternary rocks of the Western Cascades. Thus warm water is forced to, or close to, the surface along the faults bounding the west side of the High Cascades graben. The depth of the widespread diffuse flow cannot be established at the present time because there are no drill data available below $400 \mathrm{~m}$ at the west edge of the system and the permeability structure is unknown. The depth of ground water flow that effects the heat flow is as deep as or deeper than the level of the lowest point along the map, the McKenzie River at elevation of 300 to $600 \mathrm{~m}$, and must at some point go as deep as at least $1.5 \mathrm{~km}$ below the surface to heat the groundwater to the $79^{\circ} \mathrm{C}$ measured in Foley Hot Springs. Thus there is a net loss of heat along the profile through the groundwater system. Ingebritsen and others (1989) have emphasized the role of this sort of fluid flow on the heat transfer in the High Cascade Range. The Santiam Pass area comes the closest to the characteristics of their ideal model, unlike the area around Breitenbush Hot Springs where the low permeability rocks predominate the section.

The required loss of heat can be accounted for by leakage of geothermal fuid into the McKenzie River drainage at hot springs such as Belknap and Foley Hot Springs (Mariner and others, 1990) and via unexposed shallow systems such as the one encountered in EWEB-1. The inferred reservoir temperatures of the Belknap and Foley systems are only 113 and 


\section{Blackwell}

$99^{\circ} \mathrm{C}$ respectively (Brook and others, 1979), temperatures that could be reached at depths of $2 \pm 0.5 \mathrm{~km}$ in the regional gradient of $65^{\circ} \mathrm{C} / \mathrm{km}$. So there is no evidence at the present time for very hot fluid flow associated with the systems that cause the high heat flow observed along the fault zones that mark the west side of the High Cascades graben.

The general geothermal model that derives from the results described above is shown in Figure 47. The general groundwater flow regime in the area is certainly from the Cascade Range crest on the east to the McKenzie River valley on the west more or less parallel to the topographic gradient. The temperature profiles in the shallow and deep wells are consistent with this assessment. The shape of the profiles is also consistent with a permeability that decreases rapidly with depth in the outer $1 \mathrm{~km}$. In the case of the EWEB-2 well the permeability must decrease abruptly at a depth of $200 \mathrm{~m}$ to explain the abrupt change from near zero to regional gradients there. The more gradual increase in gradient with depth in the EWEB-1 and Santiam Pass 77-24 wells is consistent with a more gradual decrease in permeability with depth and/or with vertical groundwater velocities that decrease with depth. Unfortunately, neither of the wells is deep enough to definitively outline the regional thermal gradients and fluid flow conditions in this area of the High Cascade Range.

The type of flow paths expected are shown by the arrows in Figure 47. The length of the arrow indicates in a generalized way the flow velocity expected in the depth range shown. Thus the rate of flow decreases rapidly in the denth range of 500 to $1000 \mathrm{~m}$ and most of the flow is confined to depths of less than $2000 \mathrm{~m}$. The flow is complicated by the shallow, warm aquifer in EWEB-1 so that the flow pattern is not completely two-dimensional. The flow is primarily topographically driven.

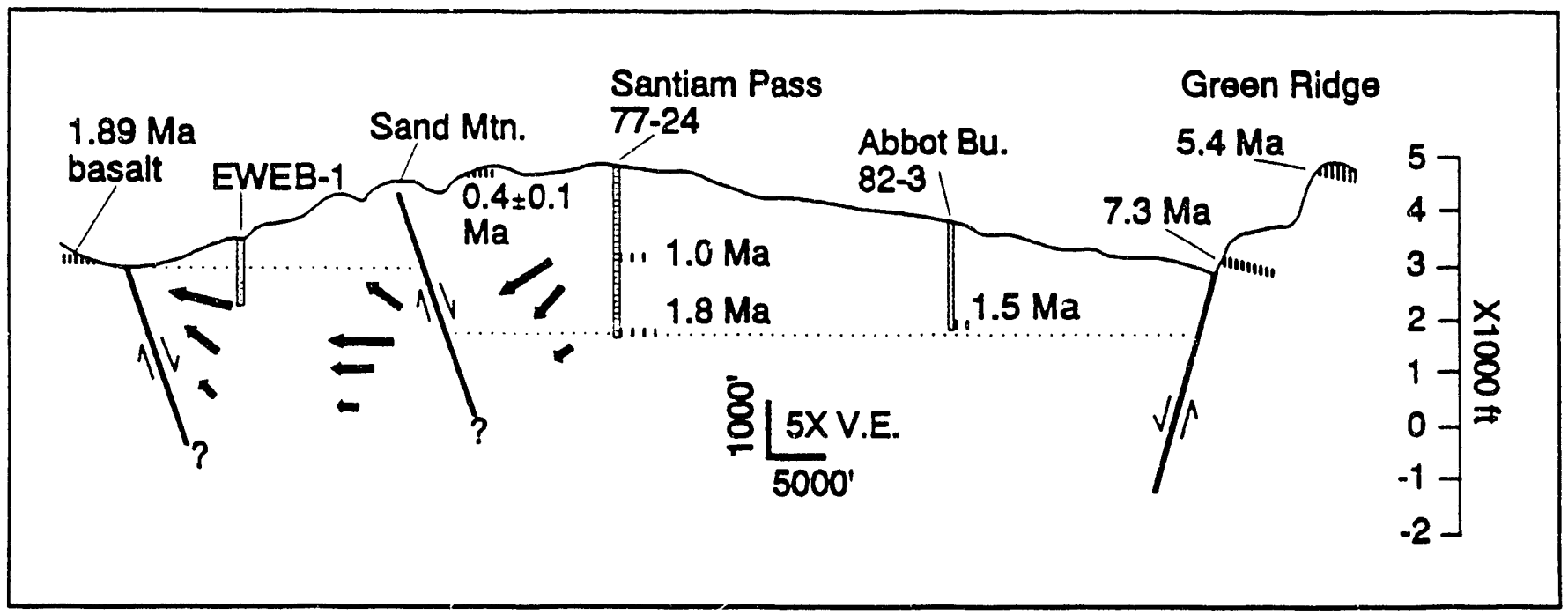

Figure 47. Interpretative cross section of the Santiam Pass area. Geology modified from Hill and others, (1991b).

\section{ACKNOWLEDGEMENTS}

I thank Robert Spafford, S.M.U. for his support in obtaining the down-hole data. Funding for this project was provided through a U.S. Department of Energy Geothermal Research Grant (DE-FG07-891D12834) to the Oregon Department of Geology and Mineral Industrics (DOGAMI), and a oce-third cost share from Oxbow Geothermal Corporation, Reno, Nevada. The shallow gradient data were made available by SUNOCO Energy Company and I 
appreciate the efforts of Edward Western to allow release of the data. Larry Carter, David Crouch and Kris Eckhardt helped with the data reduction, analysis, and figure preparation. Steve Ingebritsen and David Sherrod reviewed this manuscript and made many valuable comments.

\section{REFERENCES CITED}

Argonaut Enterprises, 1982, Tensor Magnetotelluric Survey, McKenzie Bridge Prospect, Linn and Lane Countries, Oregon: Unpublished Report to Sunoco Energy Development Company, 2 Volumes.

Bargar, K.E., 1988, Secondary mineralogy of core from geothermal drill hole CTGH-1, Cascade Range, Oregon, in Sherrod, D.R., ed., Geology and geothermal resourc s of the Breitenbush-Austin Hot Spring area, Clackamas and Marion Counties, Oregon: Oregon Department of Geology and Mineral Industries Open-File Report O-88-5, p. 3945.

Black, G.L., Woller, N.M., and Ferns, M.L., 1987, Geologic map of the Crescent Mountain area, Linn County, Oregon, scale 1:62500: Oregon Department of Geology and Mineral Industries Map GMS-47.

Blackwell, D.D., and Baker, S.L., 1988a, Thermal analysis of the Breitenbush geothermal system: Transactions of the Geothermal Resources Council, v. 12, p. 221-227.

Blackwell, D.D., and Baker, S.L., 1988b, Thermal analysis of the Breitenbush geothermal system, in Sherrod, D.R., ed., Geology and geothermal resources of the Breitenbush-Austin Hot Spring area, Clackarnas and Marion Counties, Oregon: Oregon Department of Geology and Mineral Industries Open-File Report O-88-5, p. 47-62.

Blackwell, D.D., and Spafford, R.E., 1987, Experimental methods in continental heat flow, in Sammis, C.G., and Henyey, T.L., eds.: Methods of Experimental Physics, v. 24, Geophysics, Part B, Academic Press, Orlando, Florida, p. 189-225.

Blackwell, D.D., and Steele, J.L., 1987, Geothermal data from deep holes in the Oregon Cascade Range: Transactions of the Geothermal Resources Council, v. 11, p. 317-322.

Blackwell, D.D., Boweu, R.G., Hull, D.A., Riccio, J., and Steele, J.L., 1982, Heat flow, arc volcanism, and subduction in northern Oregon: Journal of Geophysical Research, v. 87, p. 8,735-8,754.

Blackwell, D.D., Steele, J.L., Frohme, M.K., Murphey, C.F., Priest, G.R., and Black, G.L., 1990, Heat flow in the Oregon Cascade Range and its correlation with regional gravity, Curie point depths, and geology: Journal of Geophysical Research, v. 95 , p. $19,475-19,493$.

Brook, C.A., Mariner, R.H., Mabey, D.R., Swanson, J.R., Guffanti, M., and Muffler, LJ.P., 1979, Hydrothermal convection systems with reservoir temperatures $>90^{\circ} \mathrm{C}$, in Muffler, LJ.P., ed. Assessment of geothermal resources of the United States - 1978: U.S. Geological Survey Circular 790, p. $18-85$.

Cox, B.L., Gardner, G.C., and Koenig, J.B., 1981, Results of temperature gradiexi and heat flow in Santiam Pass area, Oregon: Unpublished report from GeothermEx, Inc., to Sun Energy Development Co., Dallas, Texas, 2 volumes.

Electrodyne Surveys, Reno, Nevada, 1979, A DC electrical resistivity and time domain EM survey of the Santiam Pass prospect, Linn County, Oregon: Unpublished Report to Eugene Water and Electric Board, Eugene, Oregon, 2 volumes.

Hill, B., Priest, G., Blaciweil, D.D., and Beñoit, W.R., 1991a, Scientifie results of the Santiam Pass 77-24 geothermal drilling program: Transactions of the Geothermal Resources Council, v. 15, 171-176. 


\section{Blackmell}

Hill, B., Priest, G., and Blackwell, D.D., 1991 b, Initial results from the 1990 geothermal drilling program at Santiam Pass, Oregon: Oregon Geology, v. 53, p. 101-103.

Ingebritsen, S.E., Mariner, R.H., and Sherrod, D.R., 1991, Hydrothermal systems of the Cascade Range, north-central Oregon: U.S. Geological Survey Open-File Report 91-69, 217 p.

Ingebritsen, S.E., Sherrod, D.R., and Mariner, R.H., 1989, Heat flow and hydrothermal circulation in the Cascade Range, north-central Oregon: Science, v. 243, p. 1,458-1,462.

Livelybrooks, D.W., Clingman, W.W., Rygh, J.T., Urquhart, S.A., and Waff, H.S., 1989, A magnetotelluric study of the High Cascades graben in central Oregon: Journal of Geophysical Research, v. 94, p. 14,173-14,184.

Mariner, R. H., Presser, T.S., Evans, W.C., and Pringle, M.K.W., 1990, Discharge rates of fluid and heat by thermal springs of the Cascade Range, Washington, Oregon, and Northern California: Journal of Geophysical Research, v. 95, p. 19,51719,532 .

Priest, G.R., 1990, Volcanic and tectonic evolution of the Cascade volcanic arc, $44^{\circ} 00^{\prime}$ to $44^{\circ} 52^{\prime} 30^{\prime \prime} \mathrm{N}$ : Journal of Geophysical Research, v. 92, p. 19,583-19,599.

Priest, G.R., Black, G.L., Woller, N.M., and Taylor, E.M., 1988, Geologic map of the McKenzie Bridge quadrangle, Lane County, Oregon, scale 1:62500: Oregon Department of Geology and Mineral Industries Map GMS-48.

Pritchard, J.I., and Meidav, H.T., 1975, Electrical resistivity survey of the Belknap Hot Springs-Santiam Pass project: Unpublished Report from Geonomics, Inc. to Sun Oil Company, 2 volumes.

Smith, G.A., Snee, L.A., and Taylor, E.M., 1987, Stratigraphic, sedimentologic, and petrologic record of late Miocene subsidence of the central Oregon Figh Cascades: Geology, v. 15, p. 389-392.

Steele, J.L., Blackwell, D.D., and Robison, J.H., 1982, Heat flow in the vicinity of the Mt. Hood volcano, Oregon, in Priest, G.R., and Vogt, B.F., eds., Geology and geothermal resources of the Mt. Hood area, Oregon: Oregon Department of Geology and Mineral Industries Special Paper 14, p. $31-42$.

Swanberg, C.A., and Combs, J., 1986, Geothermal drilling in the Cascade Range: Preliminary results from a 1387-m core hole, Newberry volcano, Oregon: EOS Transactions of the American Geophysical Union, v. 67, p. 578-580.

Swanberg, C.A., Walkey, W.C., and Combs, J., 1988, Core drilling and the "Rain Curtain" phenomenon at Newberry Volcano, Oregon: Journal of Geophysical Research, v. 93, p. 10,163-10,173.

Taylor, E.M., 1968, Roadside geology, Santiam and McKenzie Pass Highways, Oregon, in Dole, H.M., ed., Andesite Conference Guidebook, Oregon Department of Geology and Mineral Industries Bulletin 62, p. 3-34.

Wrighe, P.M., and Nielson, D.L., 1986, Electrical anomalies at Newberry volcano, Oregon: Comparison with alteration mineralogy in GEO corehole N-1: Transactions of the Geothermal Resources Council, v. 10, p. 247-252.

Ziagos, J.P. and Blackwell, D.D., 1986, A model for the transient temperature effects of horizontal fluid flow in geothermal systems: Journal of Volcanology and Geothermal Research, v. 27, p. 371-397. 


\section{Appendix A}

Appendix A: Description of the analytical techniques used to determine the compositions of core and surface rock samples from the Santiam Pass study area. The precision and accuracy of the INAA and XRF techniques are discussed in detail by Conrey (1991) and Hill (1991).

\section{INSTRUMENTAL NEUTRON ACTIVATION ANALYSIS}

Facilities at the Oregon State University Radiation Center were used to obtain trace element abundances through instrumental neutron activation anolysis (INAA). All samples were prepared from the fresh interiors of core and field samples, crushed in an alumina-ceramic jaw-crusher to about $0.5 \mathrm{~cm}$, split, and about $20 \mathrm{~g}$ powdered in a alumina-ceramic shatter box. In-house standards CRB-3 (equivalent to U.S.G.S. BCR-1) and CSG-1 (Champion Stock Granodiorite), and N.B.S. standard 1633-a (Fly Ash) were used as standards. About $0.8 \mathrm{~g}$ of rock powder was sealed in 2/5d polyvials, which were then sealed into a $2 \mathrm{~d}$ polyvial. The $2 \mathrm{~d}$ polyvials were double-stacked in the rotating rack of the O.S.U. TRIGA reactor, and irradiated for 6 hours at $1 \mathrm{MW}$. Gamma-ray counts were obtained using high (about 20 percent) efficiency $\mathrm{Ge}(\mathrm{Li})$ detectors coupled with 4096-channel analyzers. Data storage and reduction was accompiished with DOS-based desk top computers. First counts of $4 \mathrm{k}$ to $10 \mathrm{k}$ seconds occurred 6 to 14 days after irradiation, and obtained $\mathrm{Na}, \mathrm{Ba}, \mathrm{La}$, $\mathrm{Sm}, \mathrm{Yb}, \mathrm{Lu}$, and $\mathrm{U}$ abundances. Long counts of $15 \mathrm{k}$ to $20 \mathrm{k}$ seconds occurred 30 to 45 days after irradiation, and measured $\mathrm{Fe}, \mathrm{Sc}, \mathrm{Co}, \mathrm{Ni}, \mathrm{Rb}, \mathrm{Sr}, \mathrm{Cs}, \mathrm{Ce}, \mathrm{Nd}, \mathrm{Eu}, \mathrm{Tb}, \mathrm{Zr}, \mathrm{Hf}, \mathrm{Ta}$ and $\mathrm{Th}$ abundances.

\section{X-RAY FLUORESCENCE}

$\mathrm{X}$-ray fluorescence (XRF) analyses were performed at Washington State University, Pullman. All samples were prepared from the fresh interiors of core and field samples. Samples were crushed in a tungsten carbide (WC) jawcrusher to about $0.5 \mathrm{~cm}$ in diameter and split. About $15 \mathrm{~g}$ of the sample split was ground in a WC shatter box for 2 minutes. Rock powders were weighed to $3.5000 \pm 0.0003 \mathrm{~g}$ and combined with $7.0000 \pm 0.0003 \mathrm{~g}$ of lithium tetraborate flux and mechanically homogenized for 10 minutes. A 2:1 flux-to-rock ratio was used to increase the precision of trace element analyses. However, this ratio results in larger matrix corrections during XRF analysis, which may introduce a bias towards higher $\mathrm{SiO}_{2}$ (+0.5 wt. percent) and lower $\mathrm{FeO} * \mathrm{CaO}$, and $\mathrm{TiO}_{2}(-0.5$ wt. percent) in W.S.U. analyses. The homogenized powder was then fused in graphite crucibles at $1000^{\circ} \mathrm{C}$ for 35 minutes, cooled, reground and refused. The glass beads were then ground flat with 240 and 600 alumina carbide grit, cleaned in an ultrasonic cleaner and washed in lab-grade alcohol. Glass beads were analyzed in a fully automated Rigaku 3370 X-ray spectrometer.

\section{REFERENCES CITED}

Conrey, R.M, 1991, Geology and petrology of the Mt. Jefferson area, High Cascade Range, Oregon: Pullman, Washington State University, $\mathrm{Ph} . \mathrm{D}$. dissertation, $357 \mathrm{p}$.

Hill, B.E, 1991, Petrogenesis of compositionally distinct silicic volcanoes in the Three Sisters region of the Oregon Cascade Range: The effects of crustal extension on the development of continental arc silicic magmatism: Corvallis, Oregon State University, Ph.D. dissertation, 235 p. 


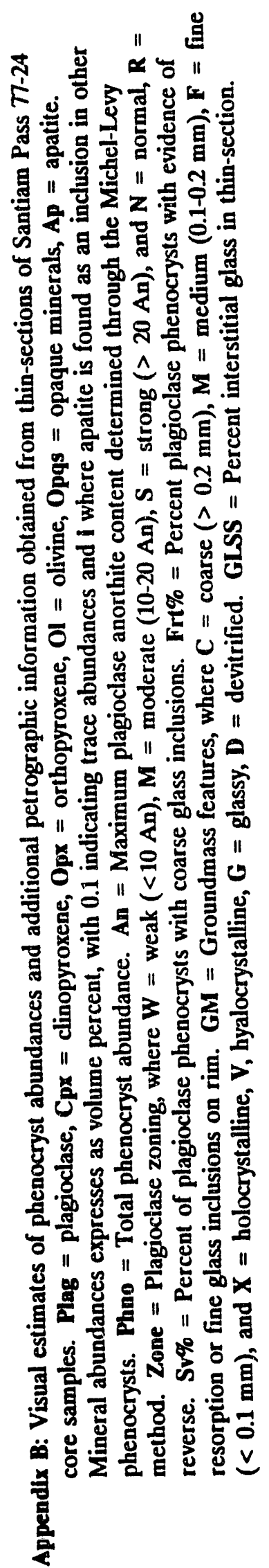

Open-File Report 0.92-3
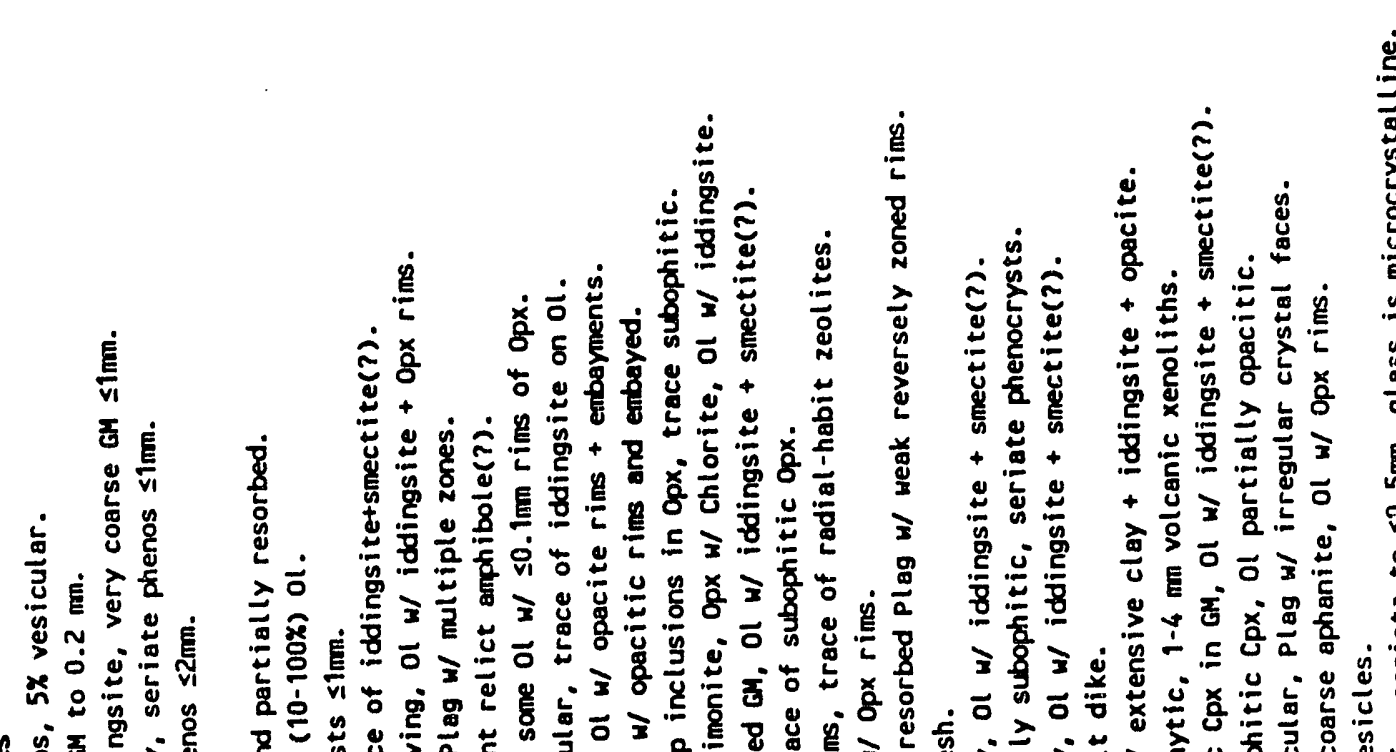

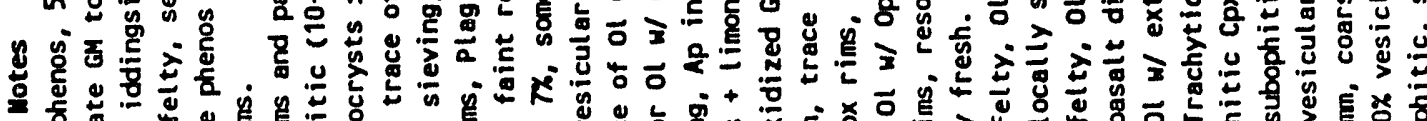

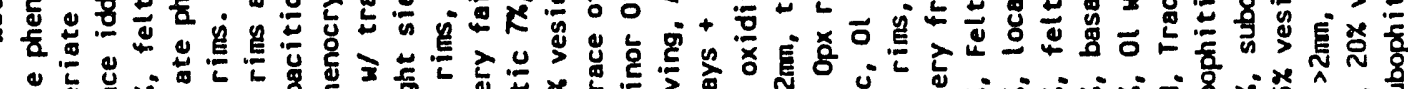

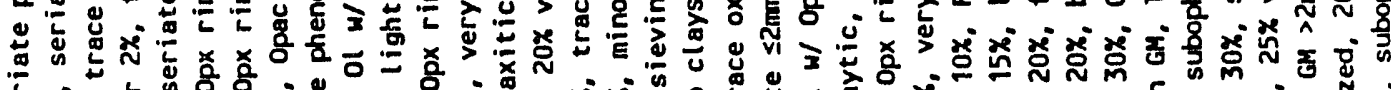

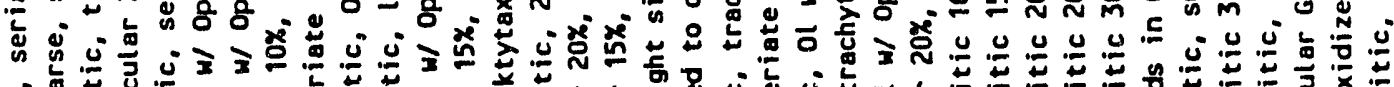

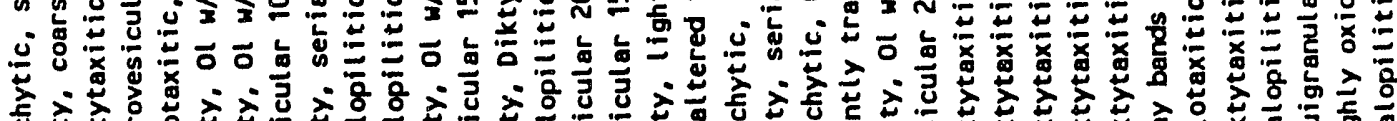

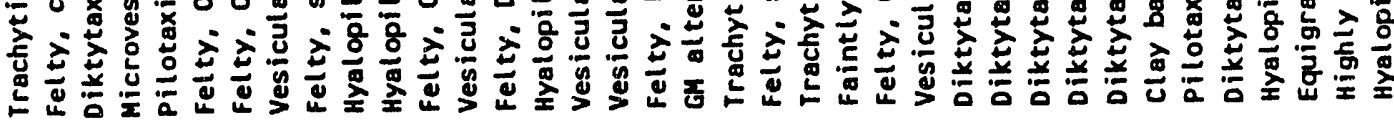

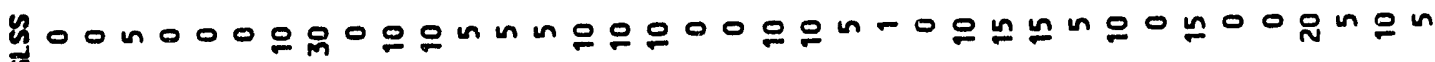

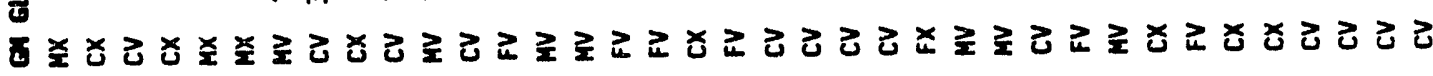
\$000000000000000000000 N N00000000000000

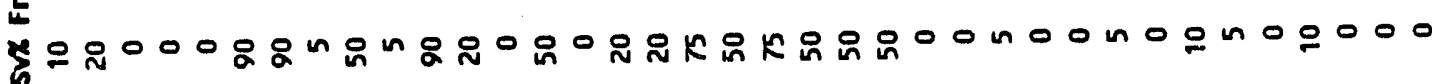

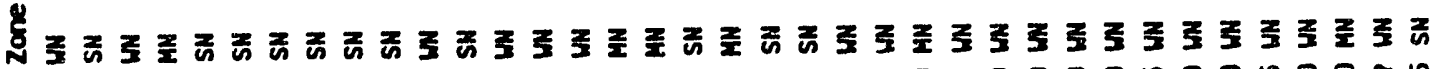
ร

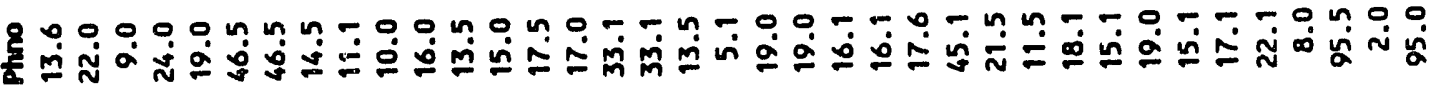
2

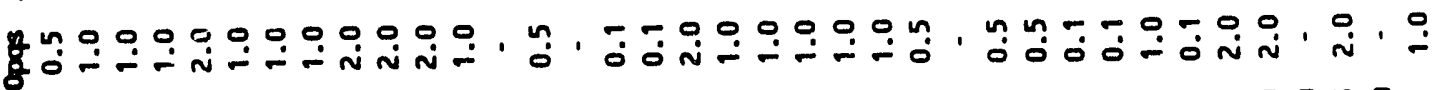

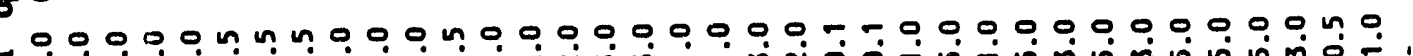

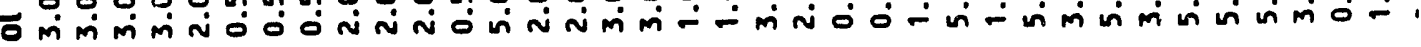

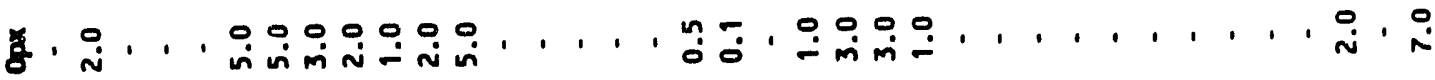

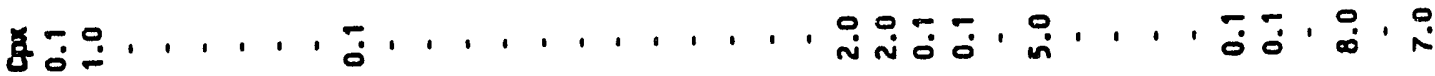

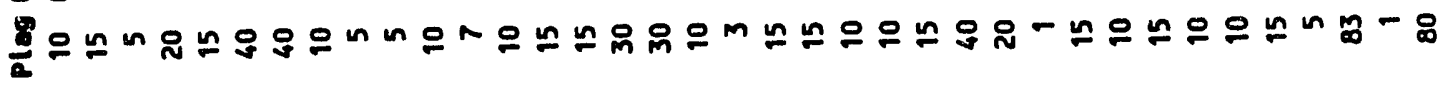

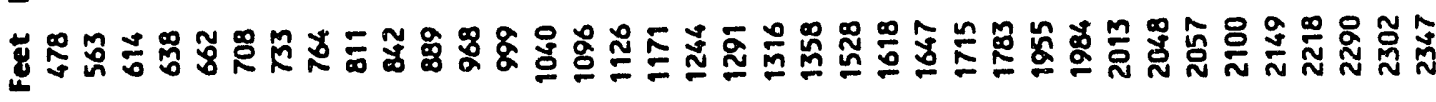




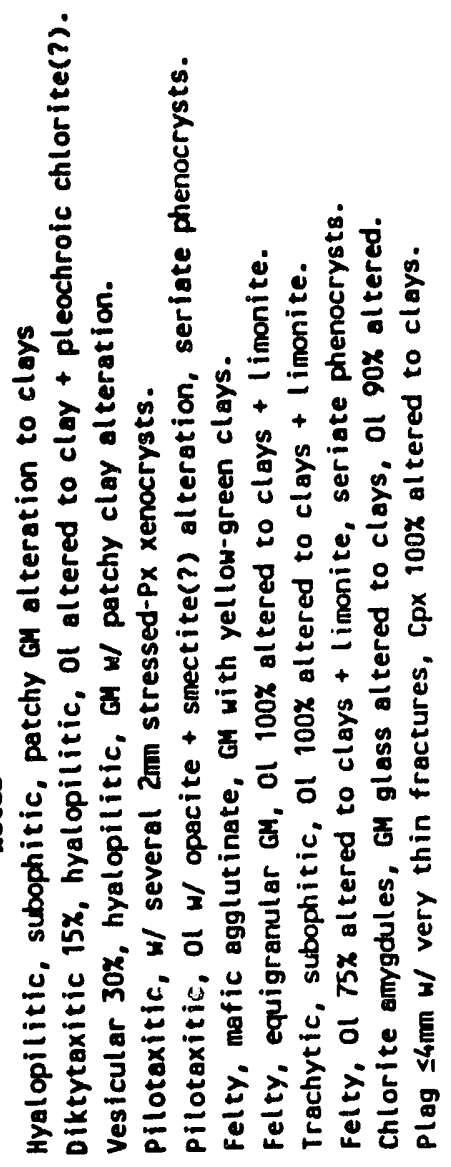

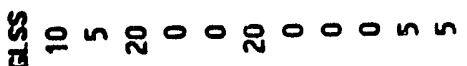

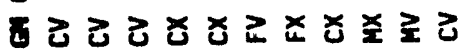
स0000\%000000

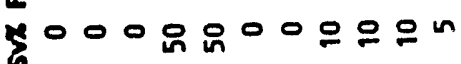

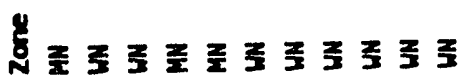

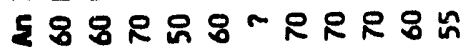

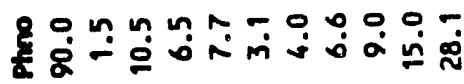
2., , , . . . .

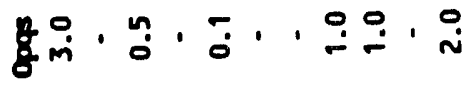
б

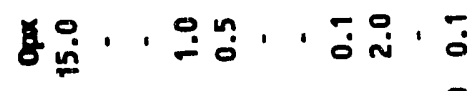

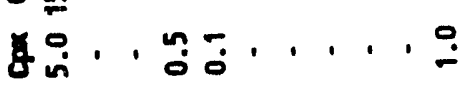
$\frac{8}{2} 8-\sim$ m n m m n m 0 은

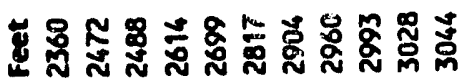

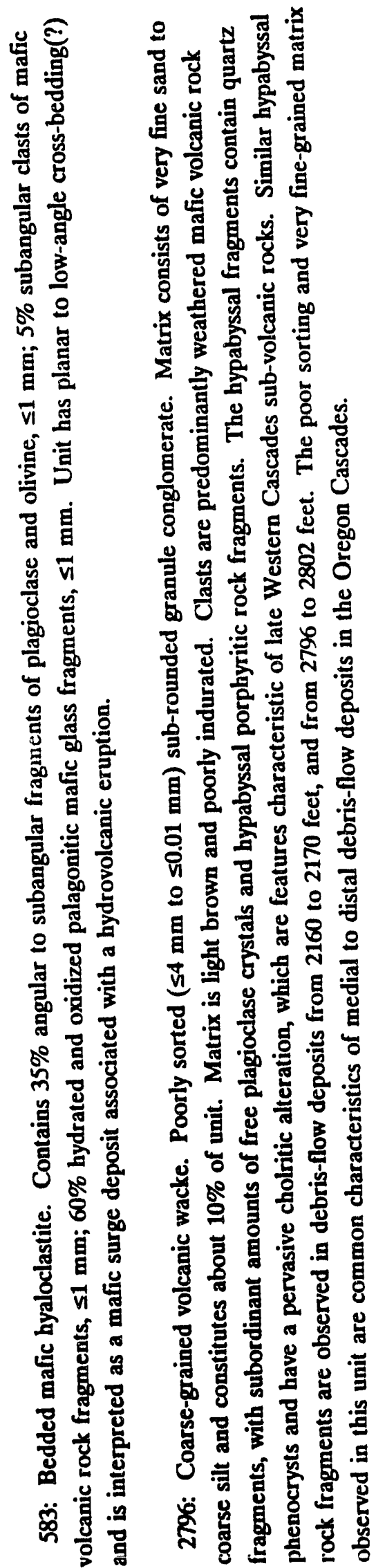




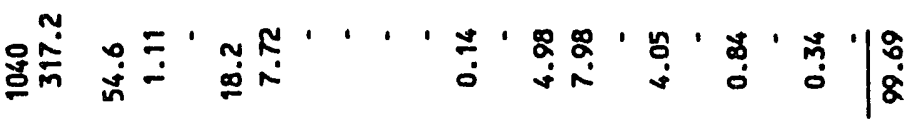

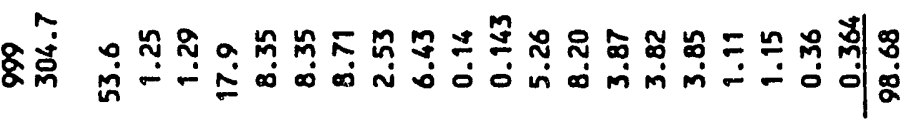

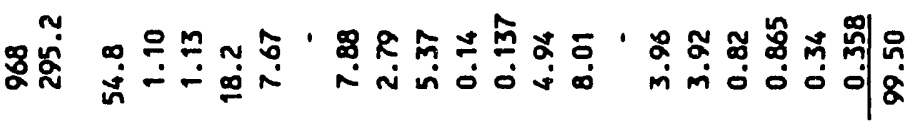

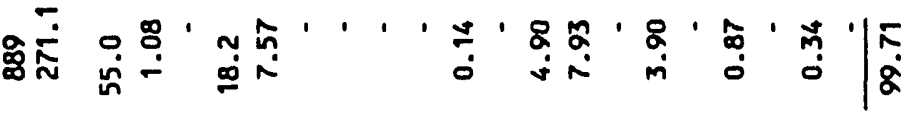

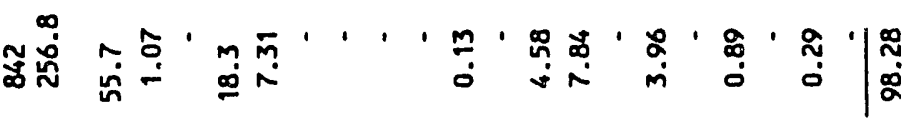

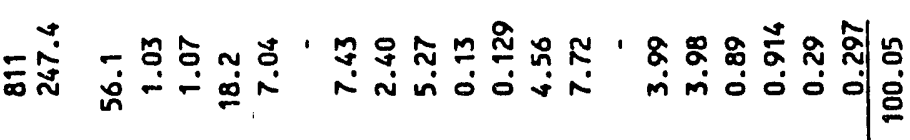

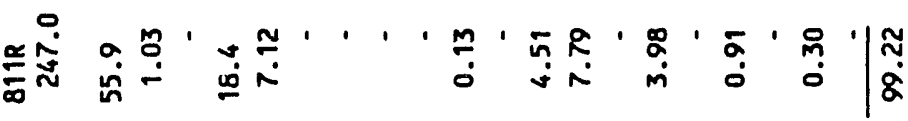

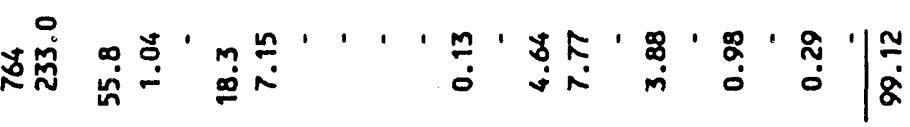

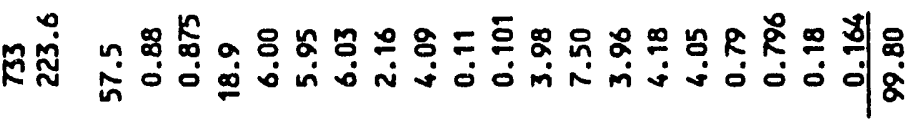

象究

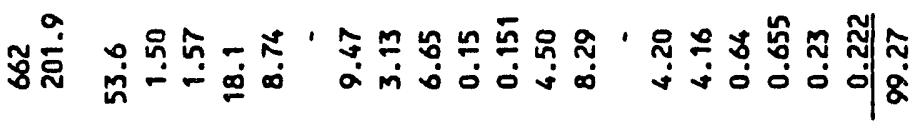

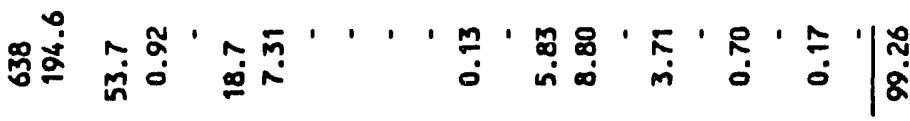

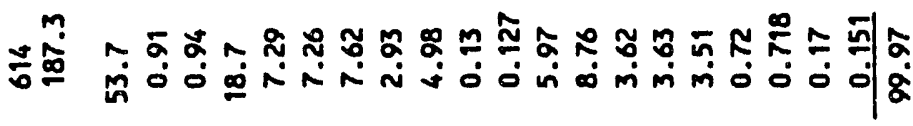

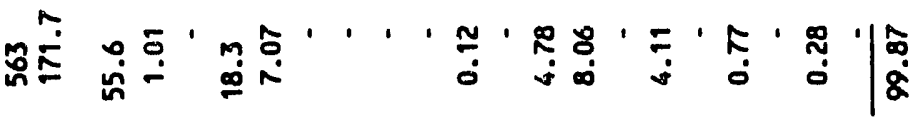

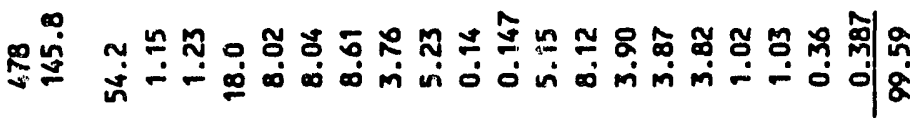

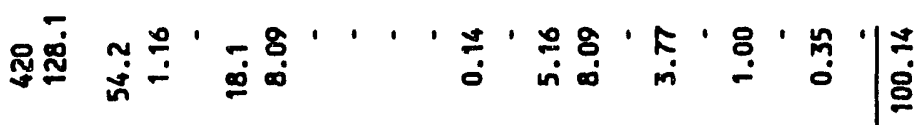

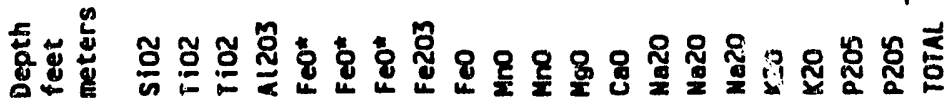

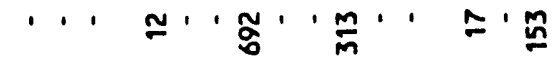

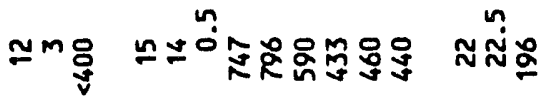

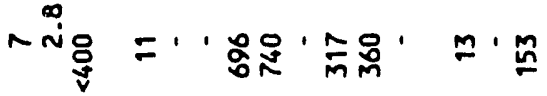
$\cdots$ ำ

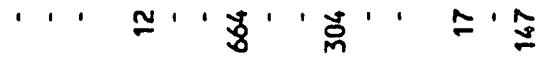

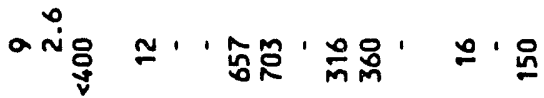

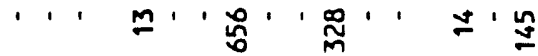

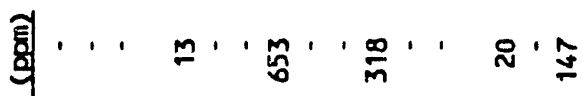
新范 綰 ㅇ' $\bar{\kappa} \cdot$ '

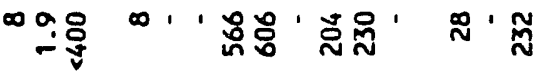

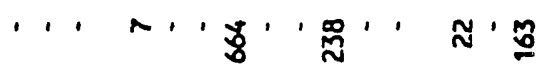
๓ฺ̣:

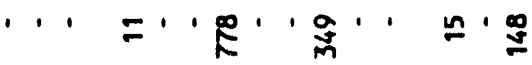

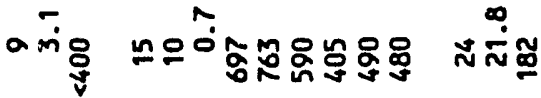

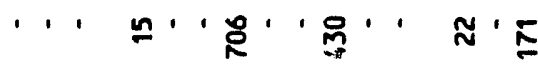

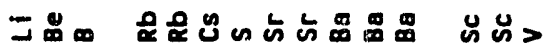
56 


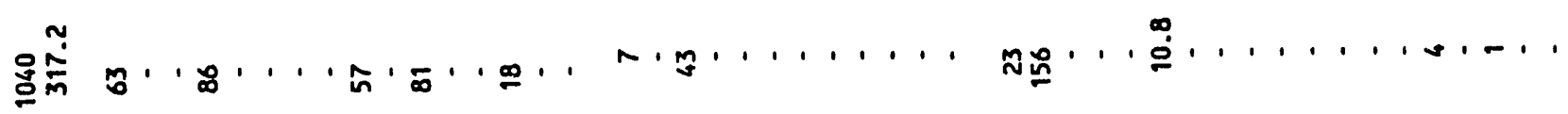

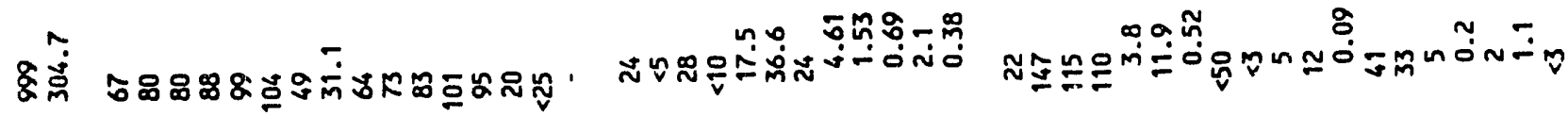

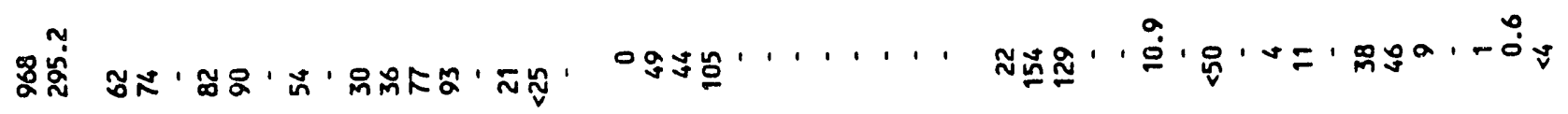
这

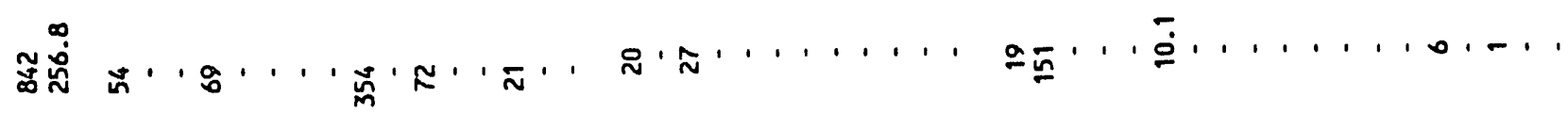

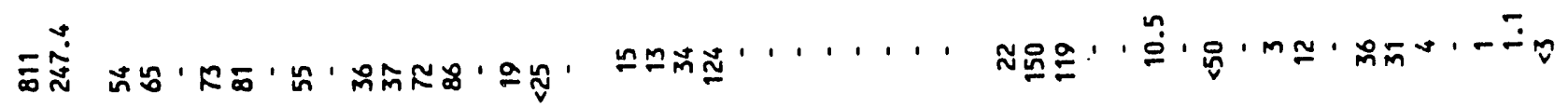

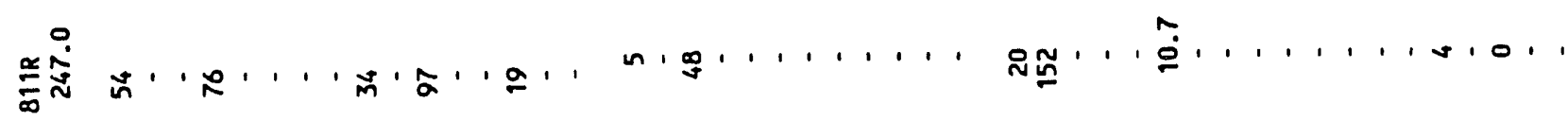

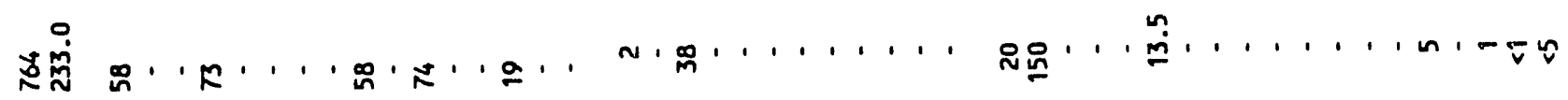

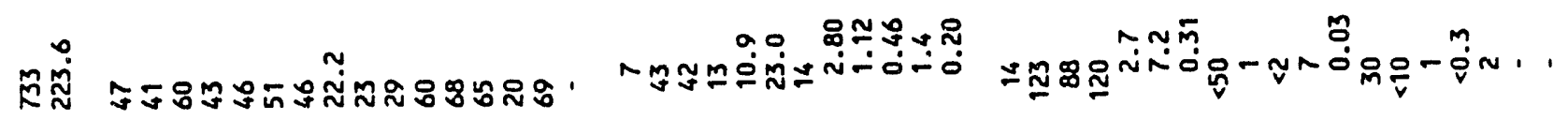
㝵空

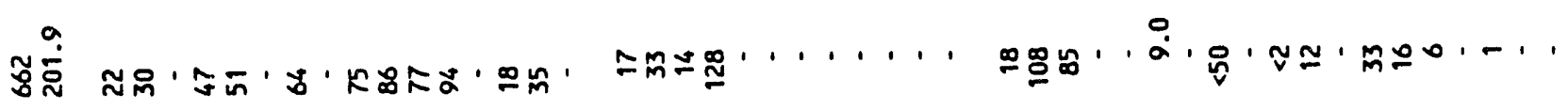

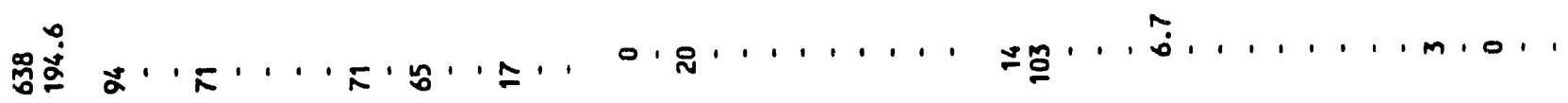

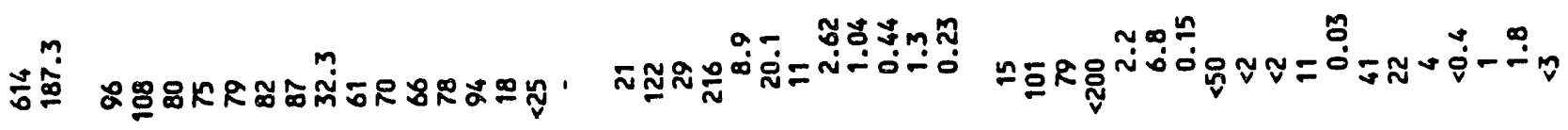

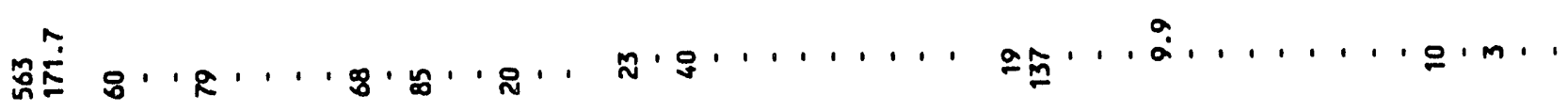

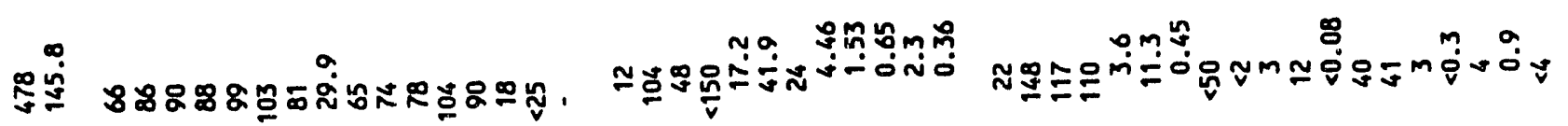

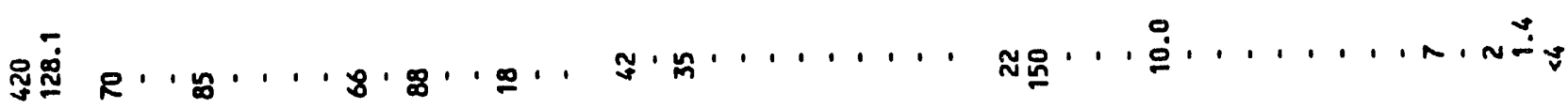

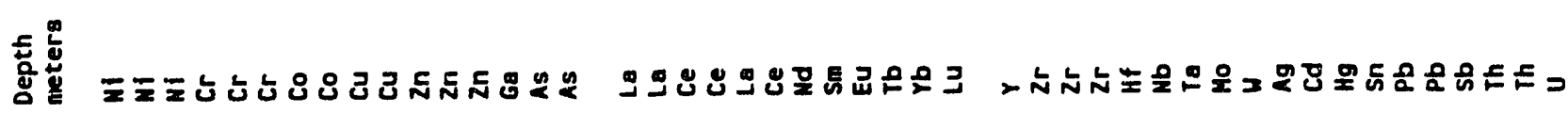
$x-<x-<-<x-x-<x-<$ 
造商 过

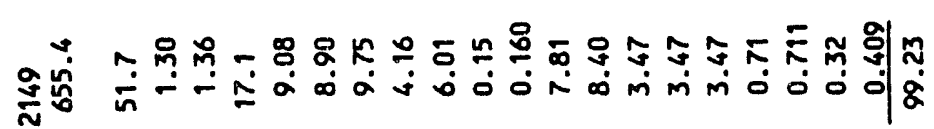

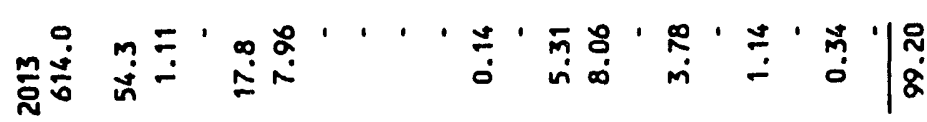

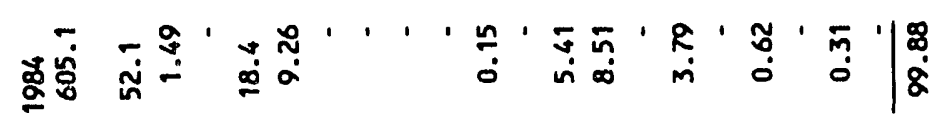

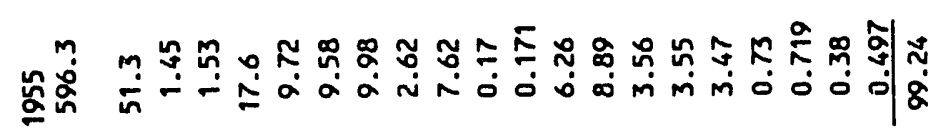

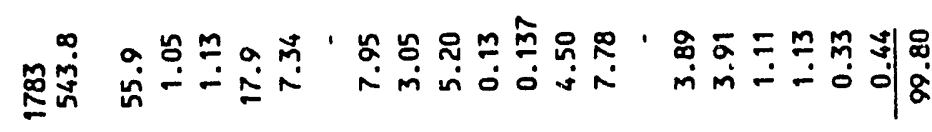

叁芯

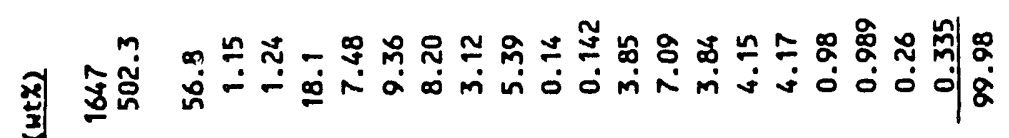

隺

雚

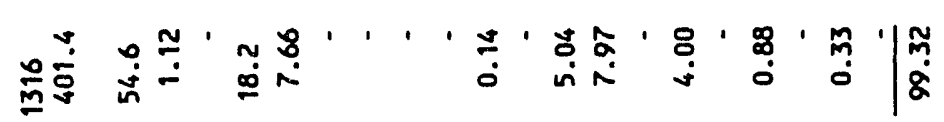

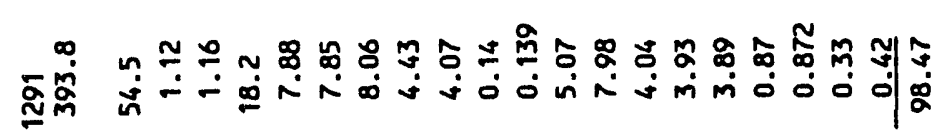

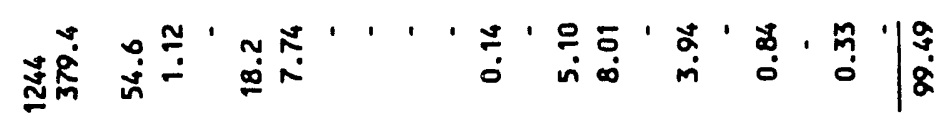

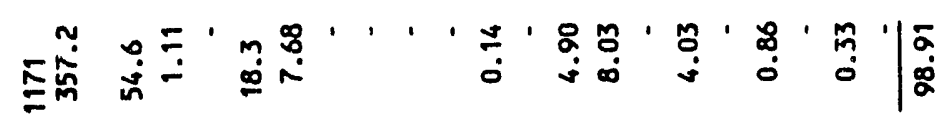

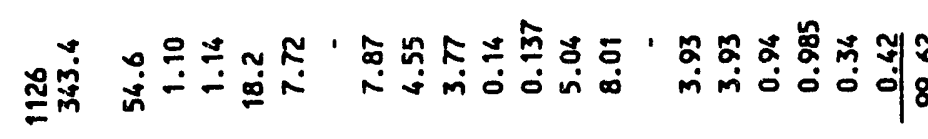

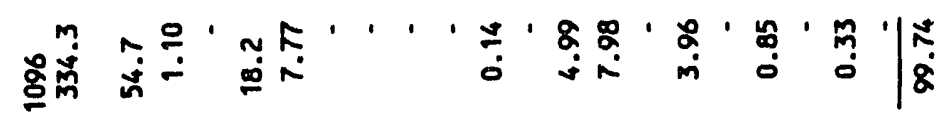

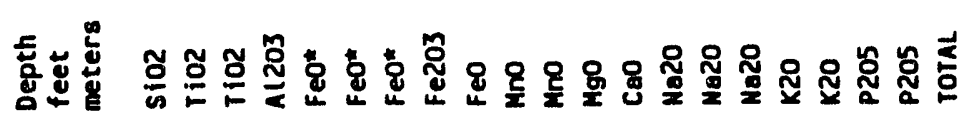
Open-File Report ${ }^{x} \times-92-3$ am

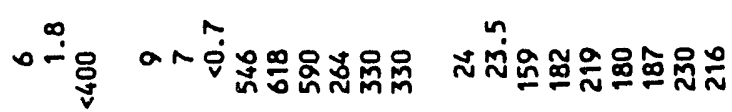
드ำ

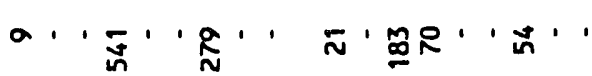

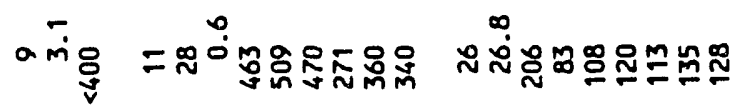

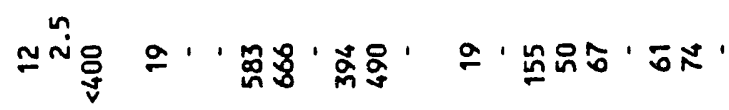

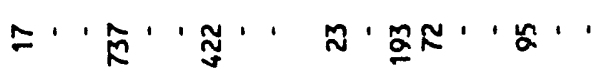

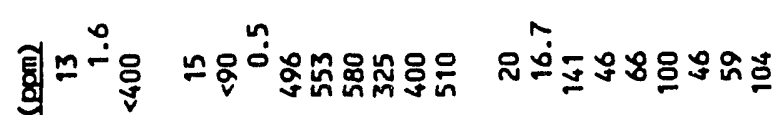

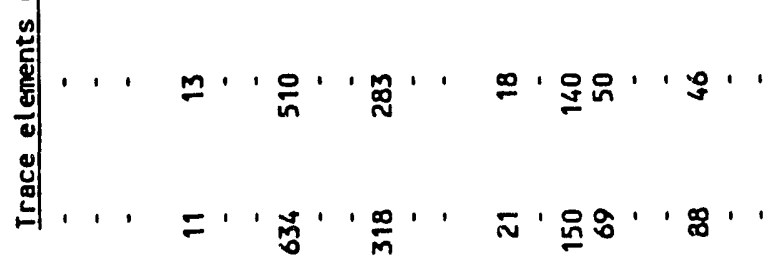

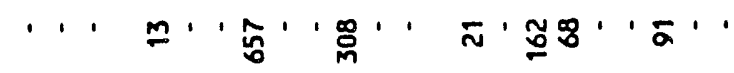

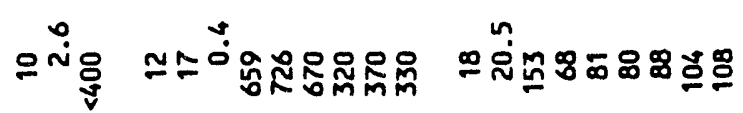

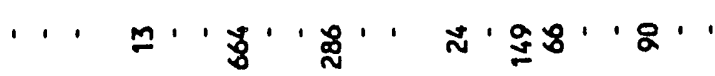

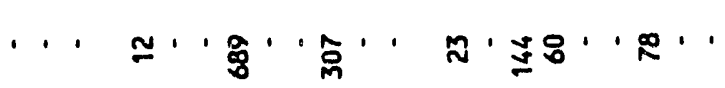

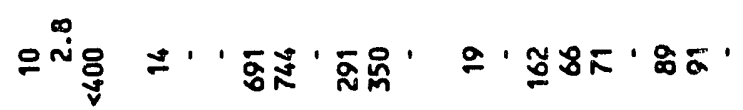

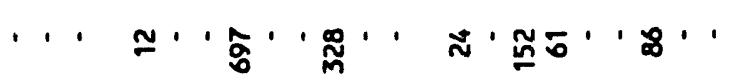

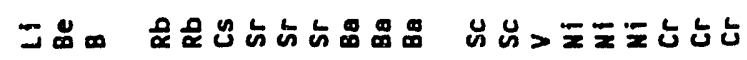
- $-x<<x-<x-<<x<x-<x-<$ 


\section{Appendix C}

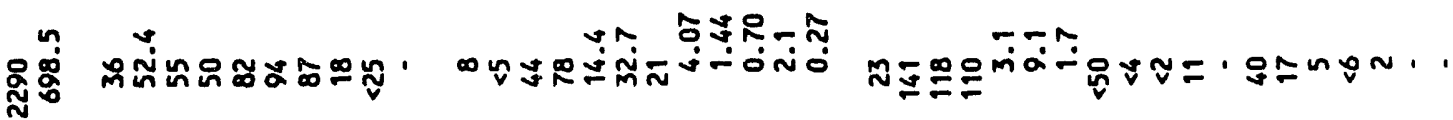

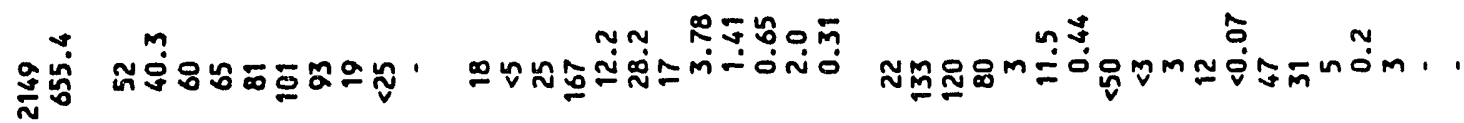

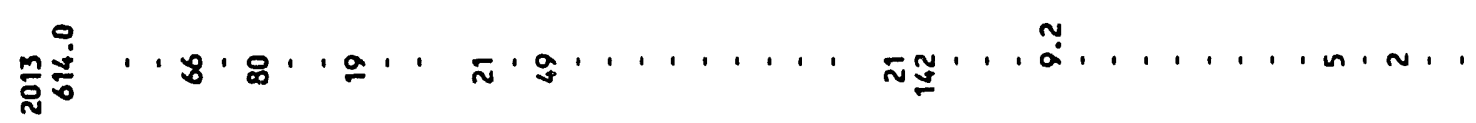

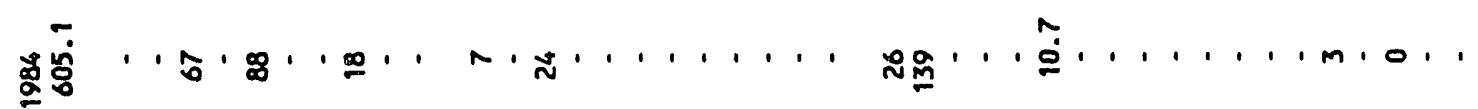

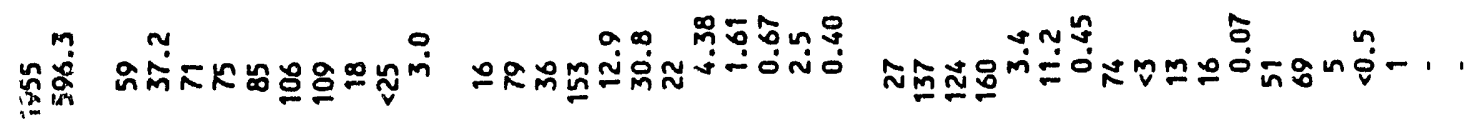

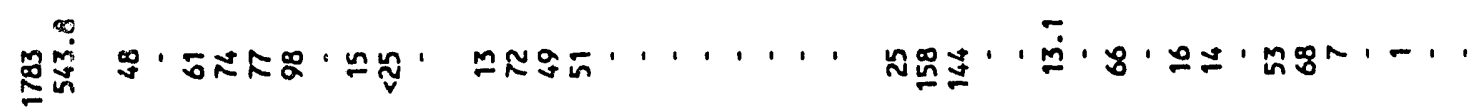

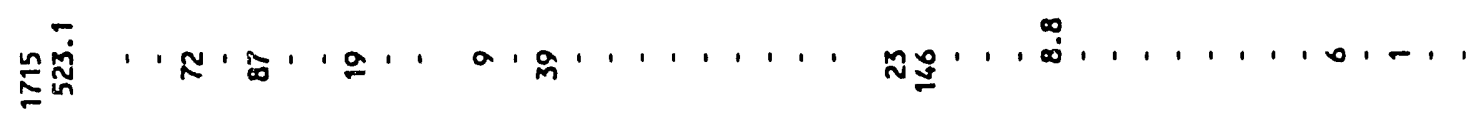

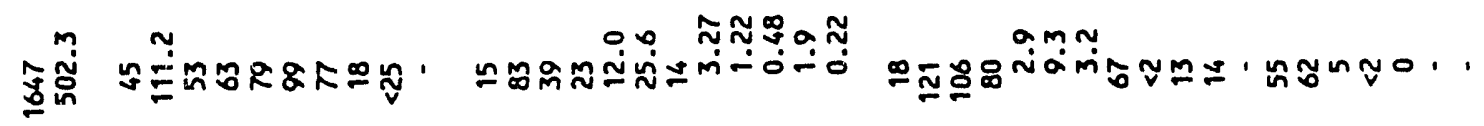

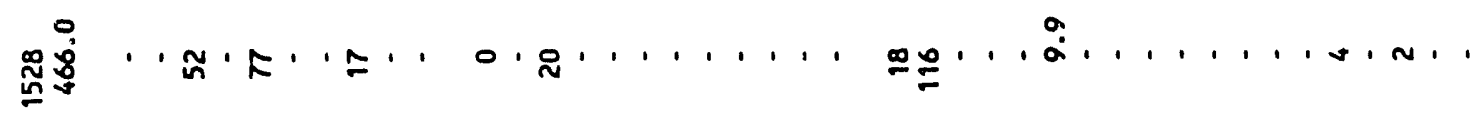

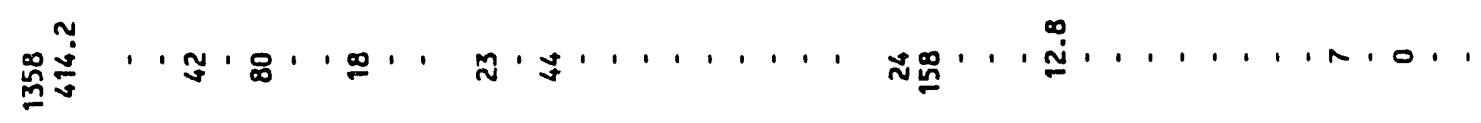

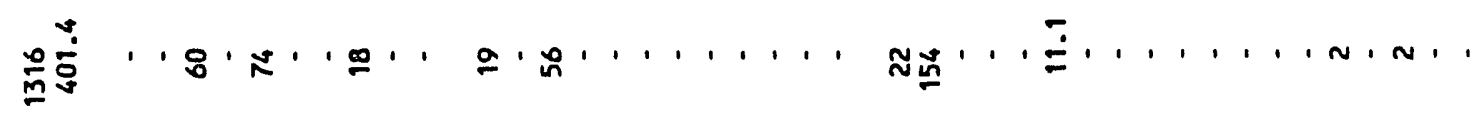

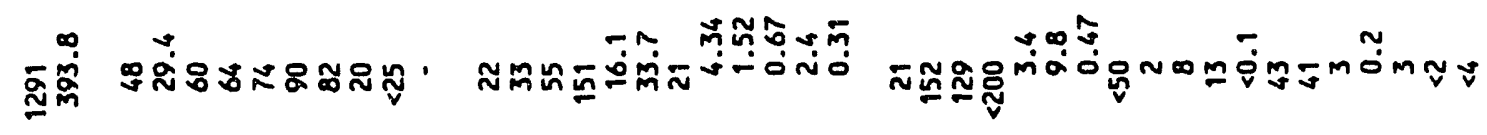

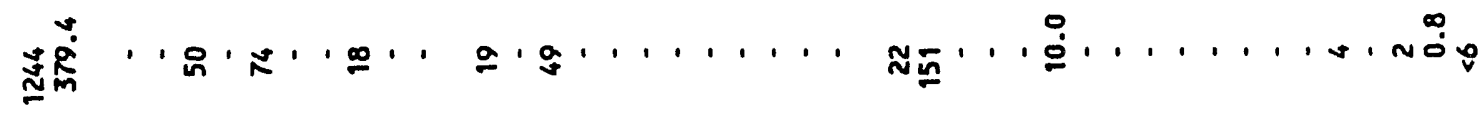

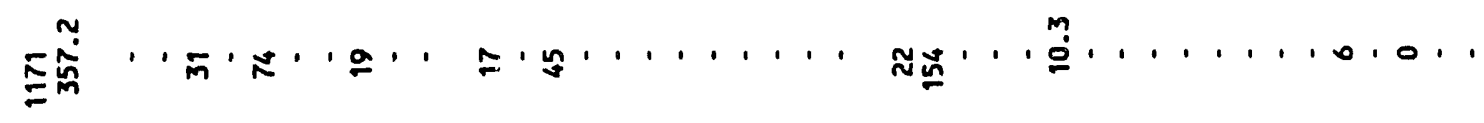

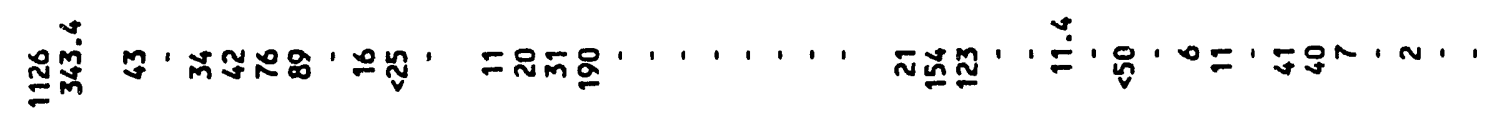

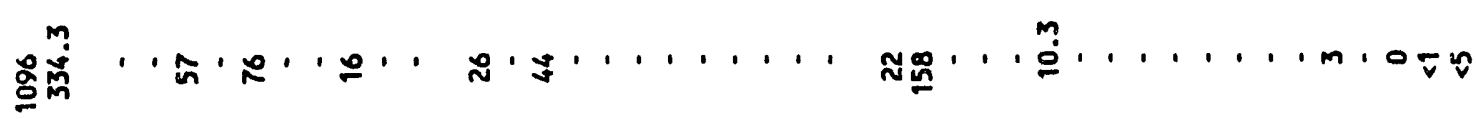

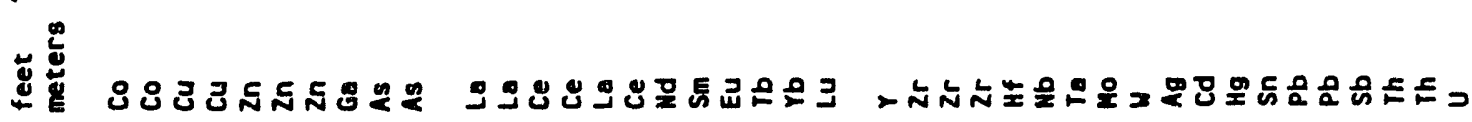

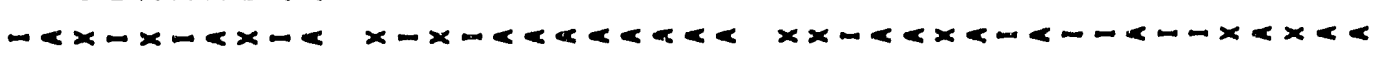




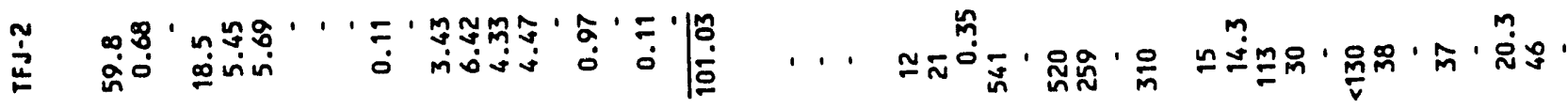

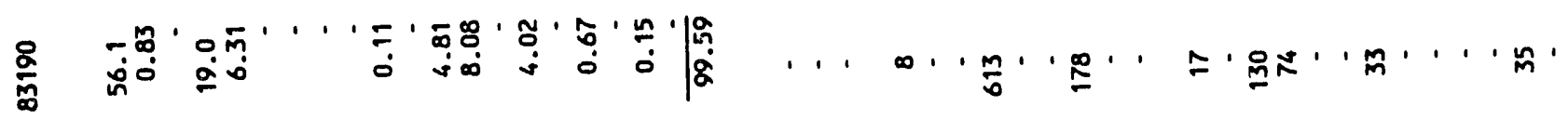

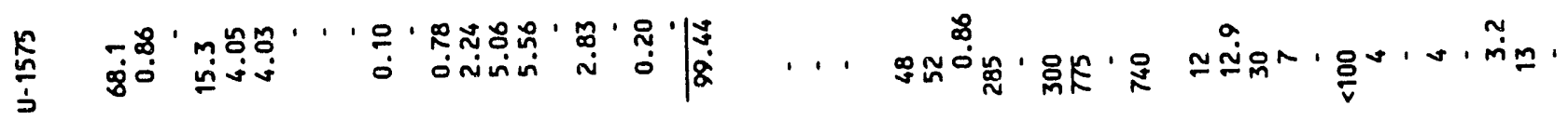

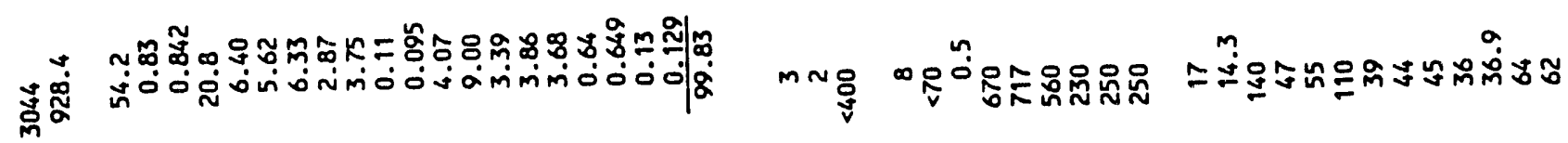

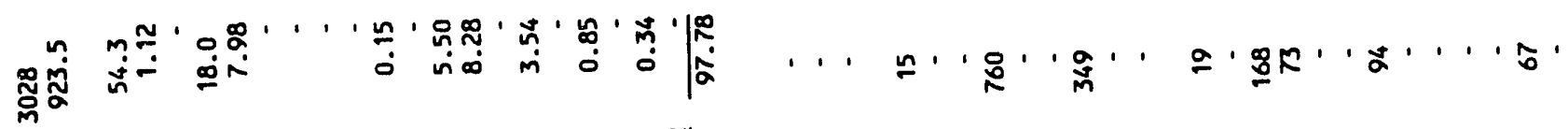

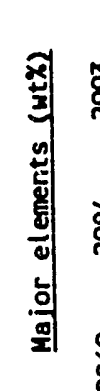

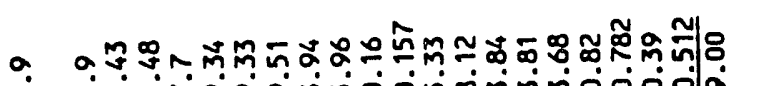

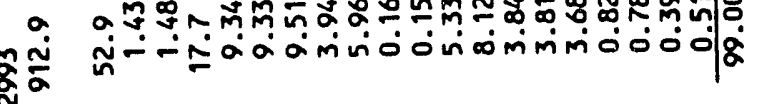

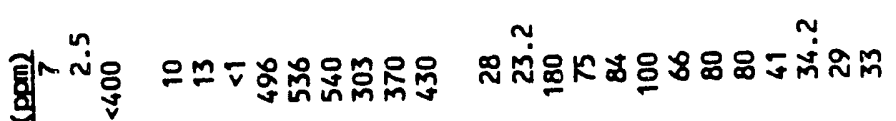

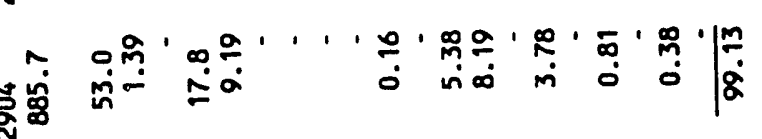

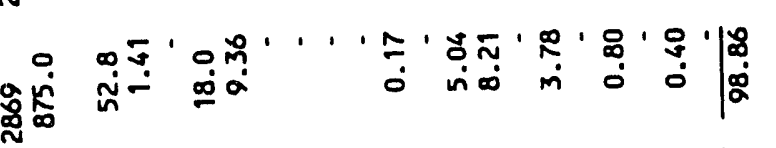

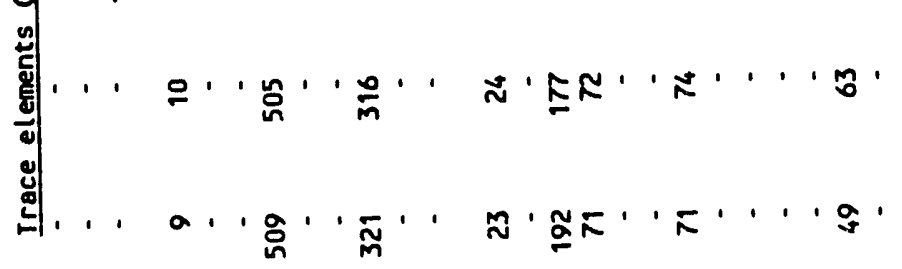

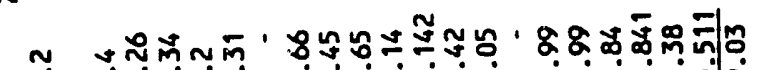

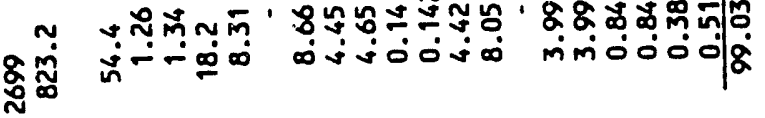

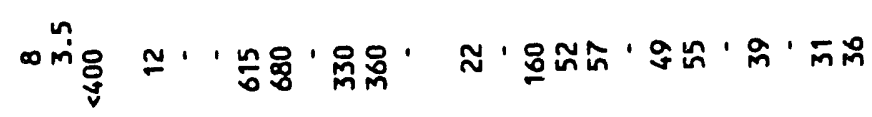

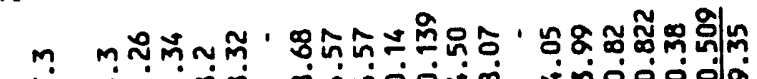

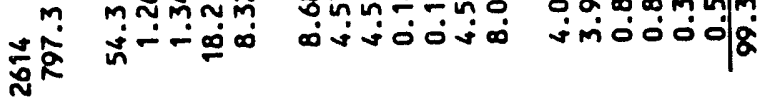

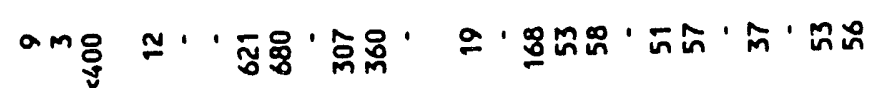
顼 总

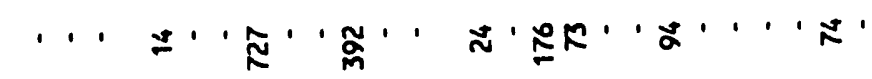

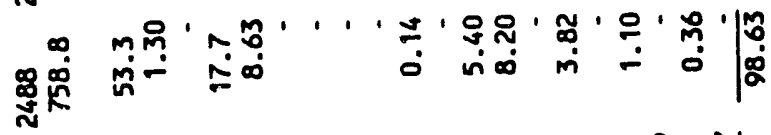
, n '

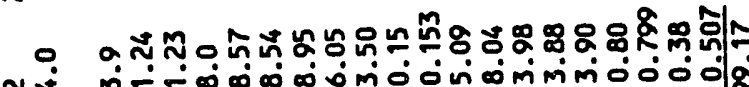

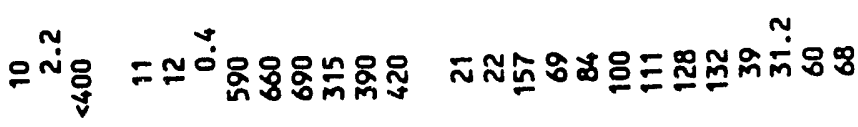

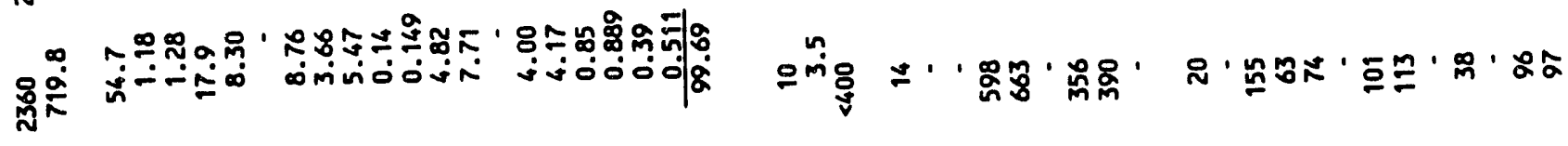

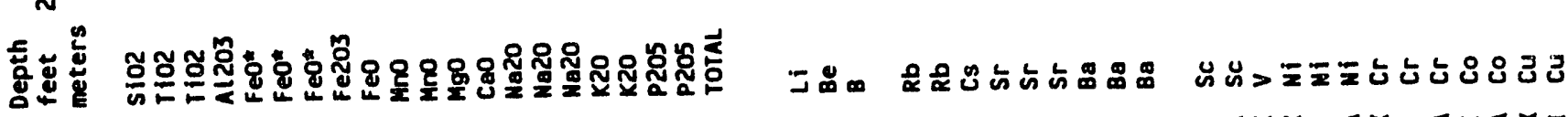




\section{Appendix C}

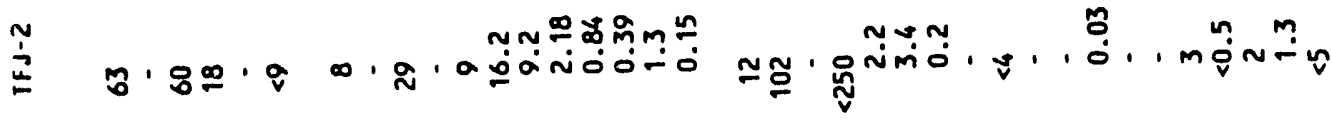

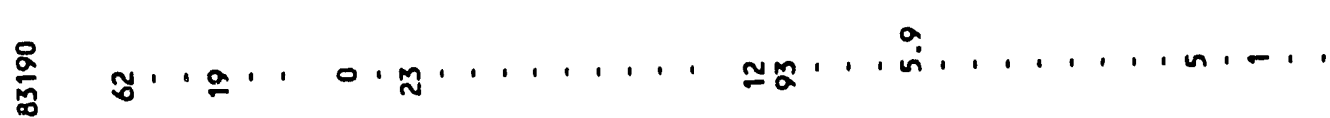

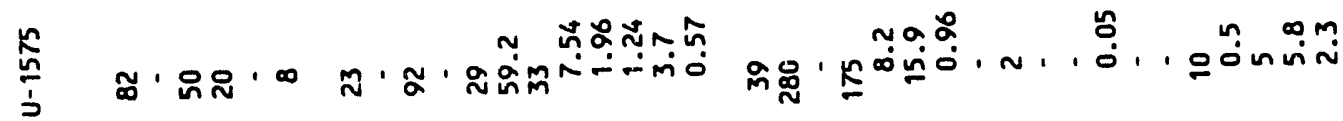

䒠苔

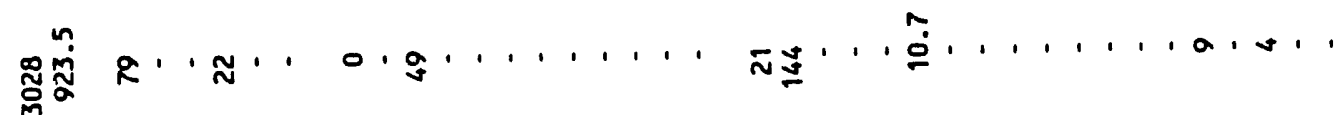

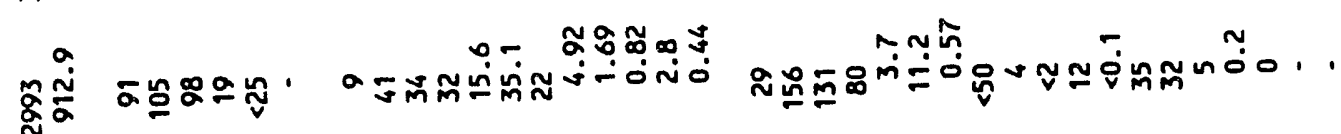

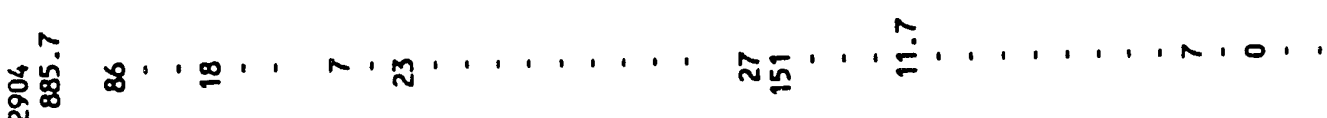

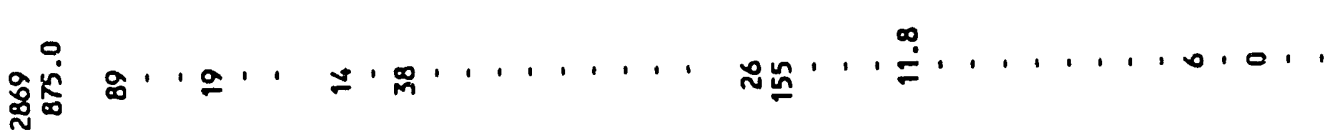

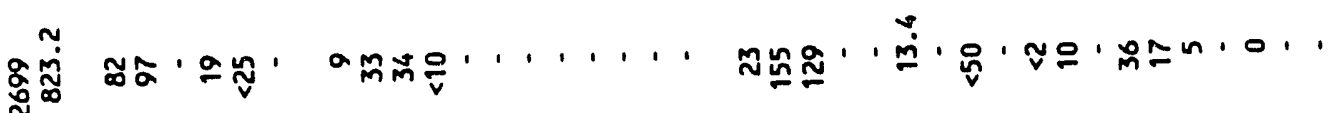

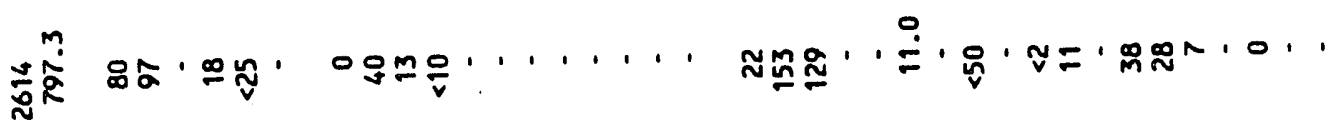

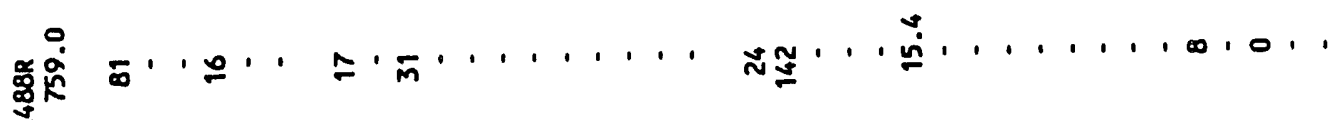

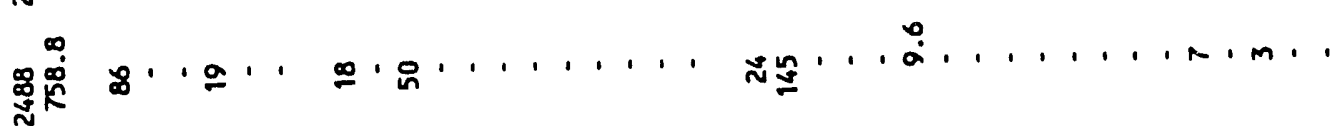

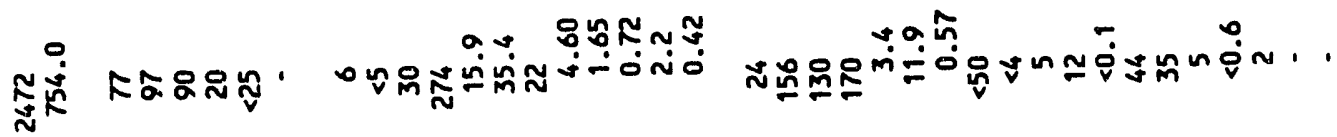

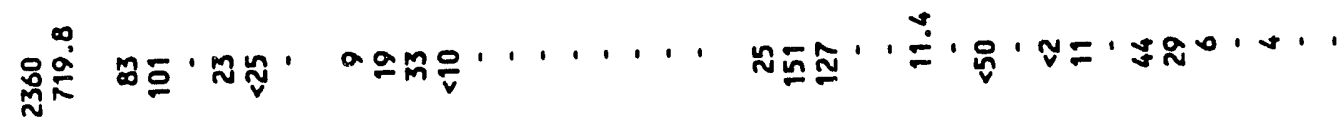

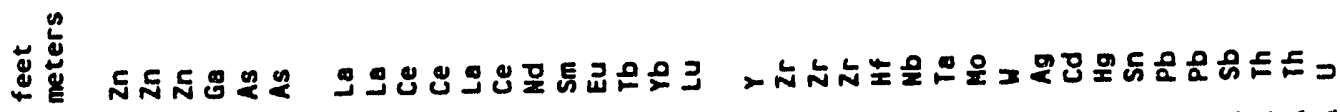

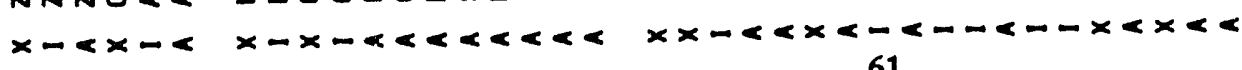


STATE OF OREGON

DEPARTMENT OF GEOLOGY AND MINERAL INDUSTRIES

DONALD A. HULL, STATE GEOLOGIST

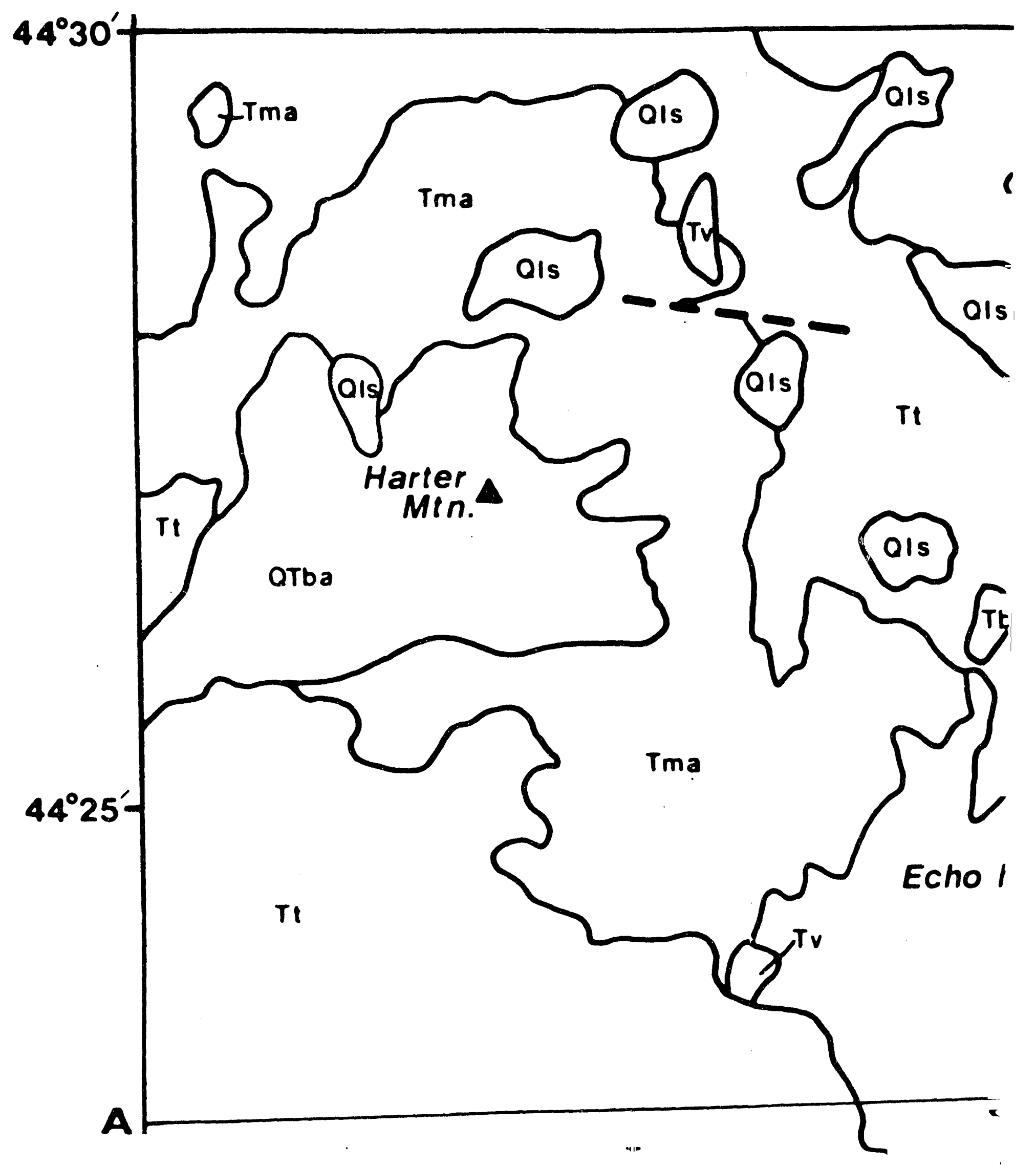




\section{GEOLOC \\ OF THE OREGC}

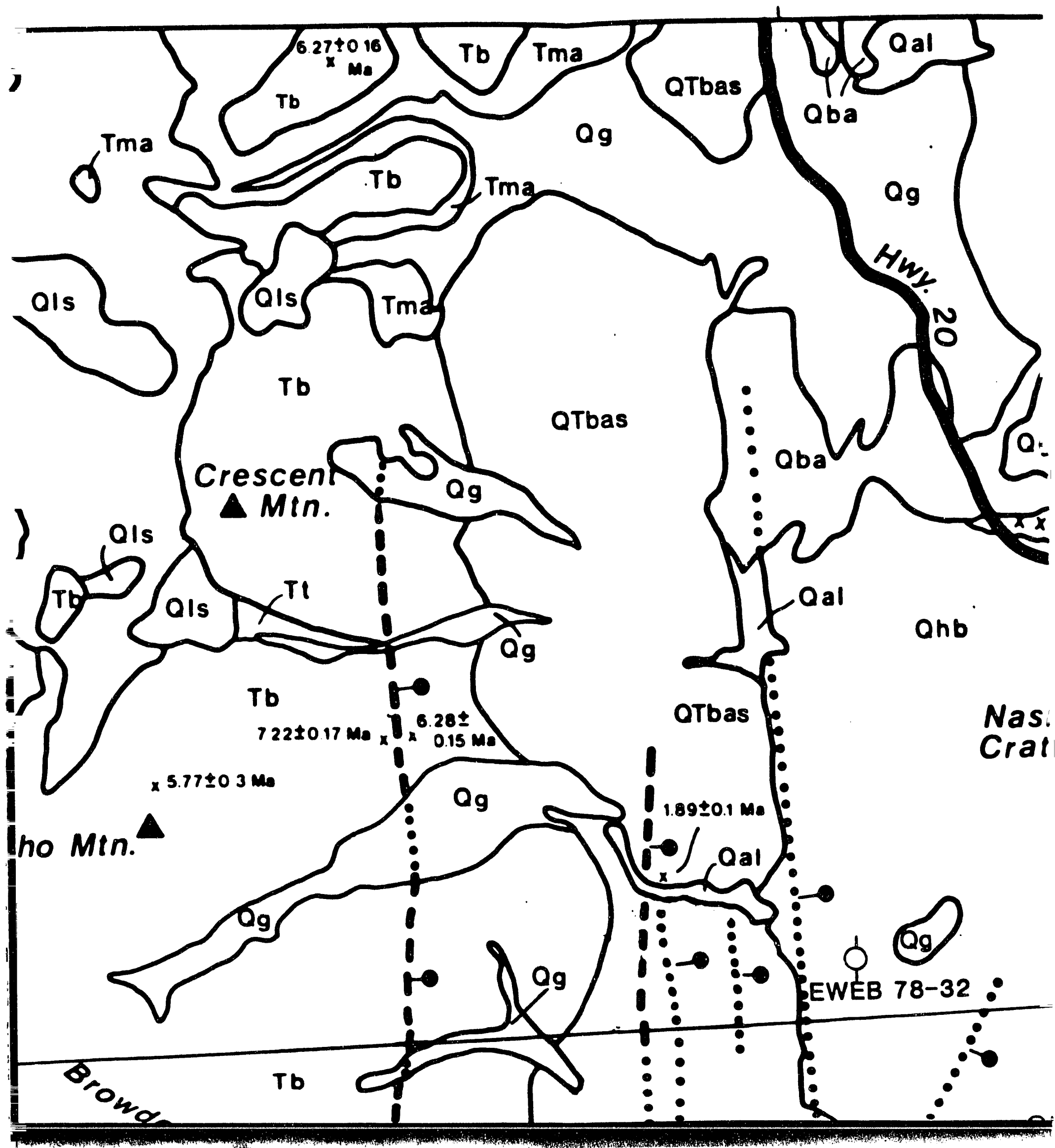


JLOGY AND GEOTHERMAL RESOUHLiES NIAT' UEEGON CASCADE RANGE, DESCHUTES, JEFFERSOI

1992

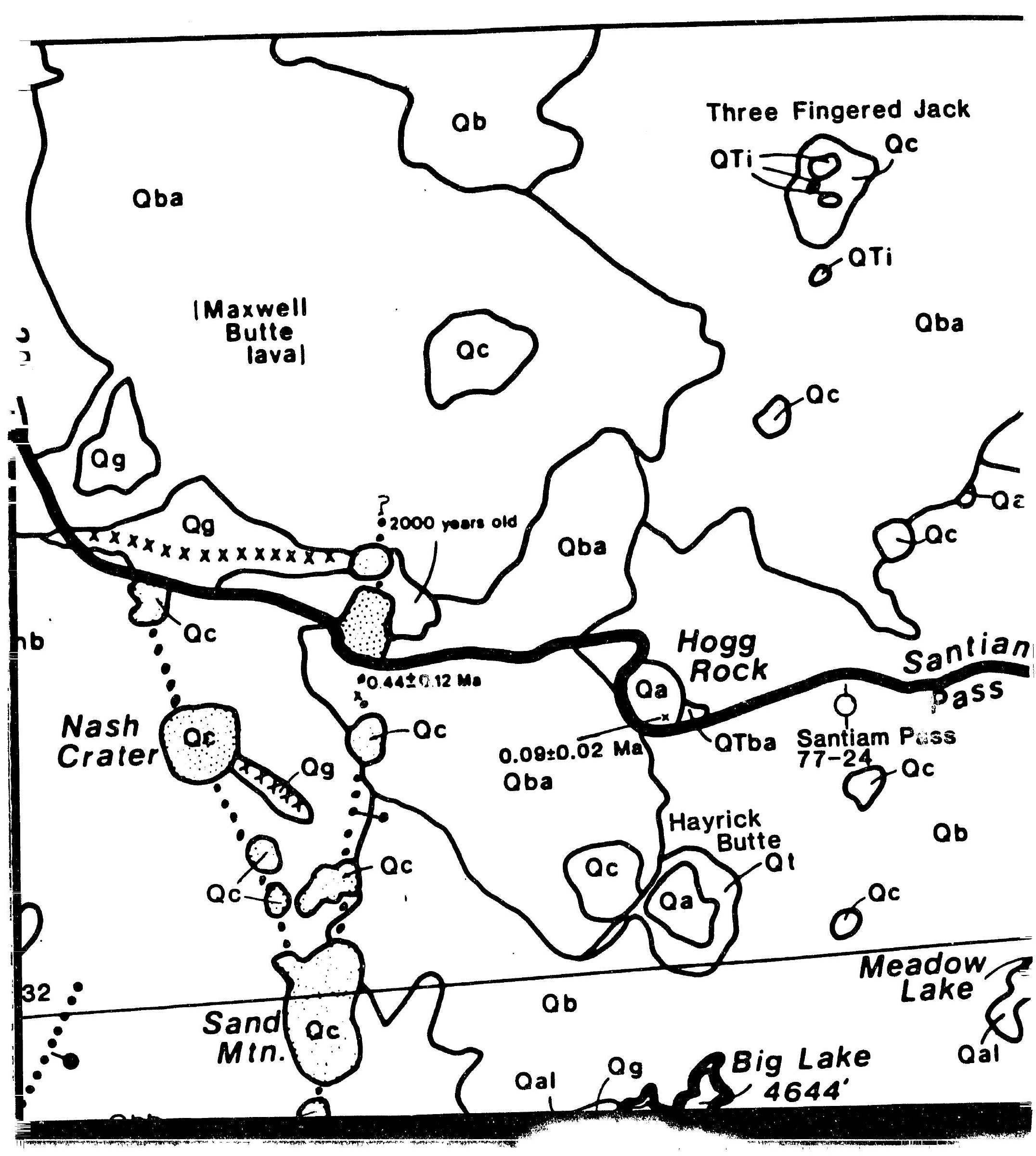


JF THE SANTIAM PASS AREA

SON AND LINN COUNTIES, OREGON

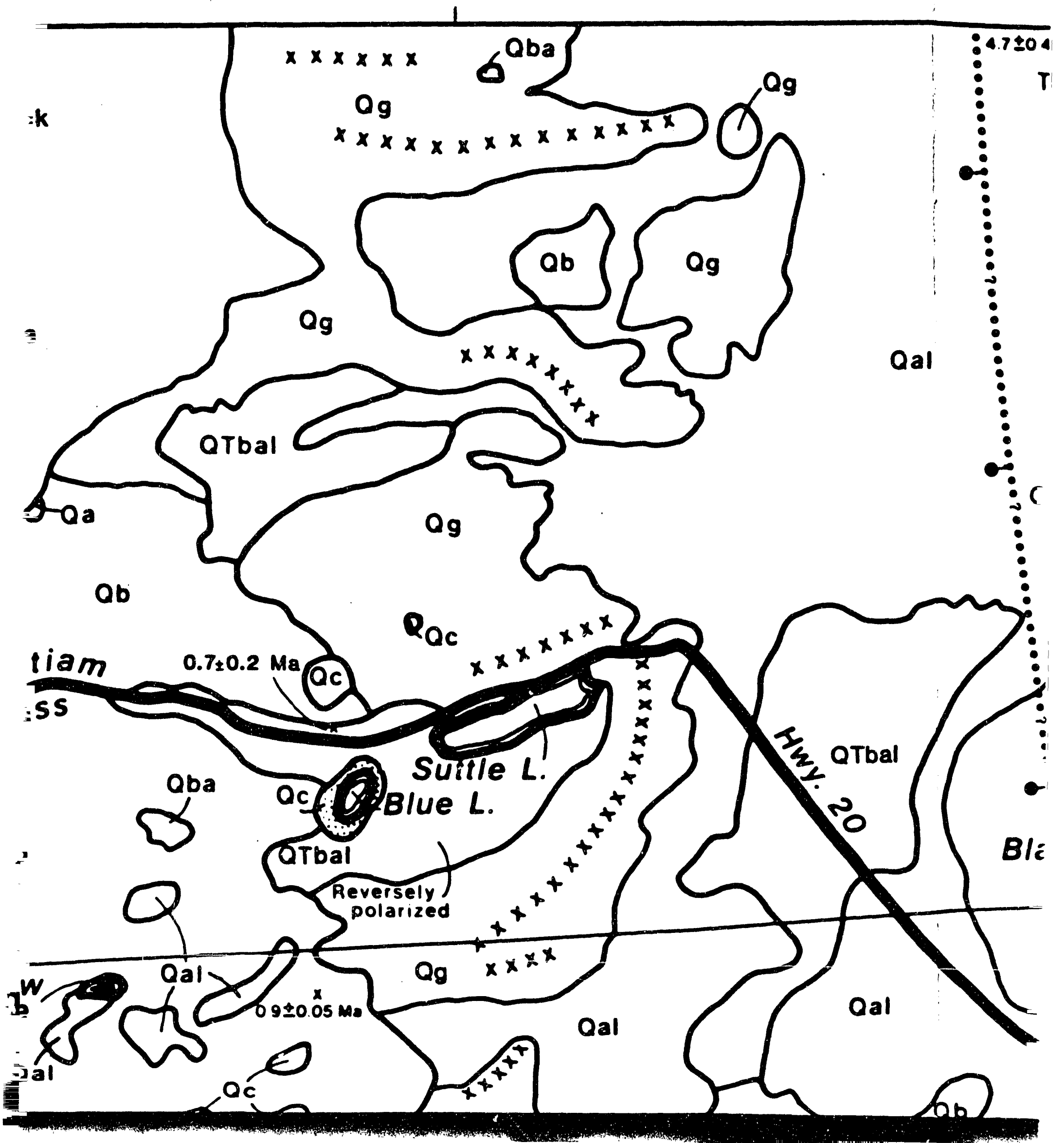


OPEN-FILE REPORT 0-92-3

GEOLOGY AND GEOTHERMAL RESOURCES OF THE

SANTIAM PASS AREA OF THE OREGON CASCADE

RANGE, DESCHUTES, JEFFERSON AND

LINN COUNTIES, OREGON

By Britain E. Hill

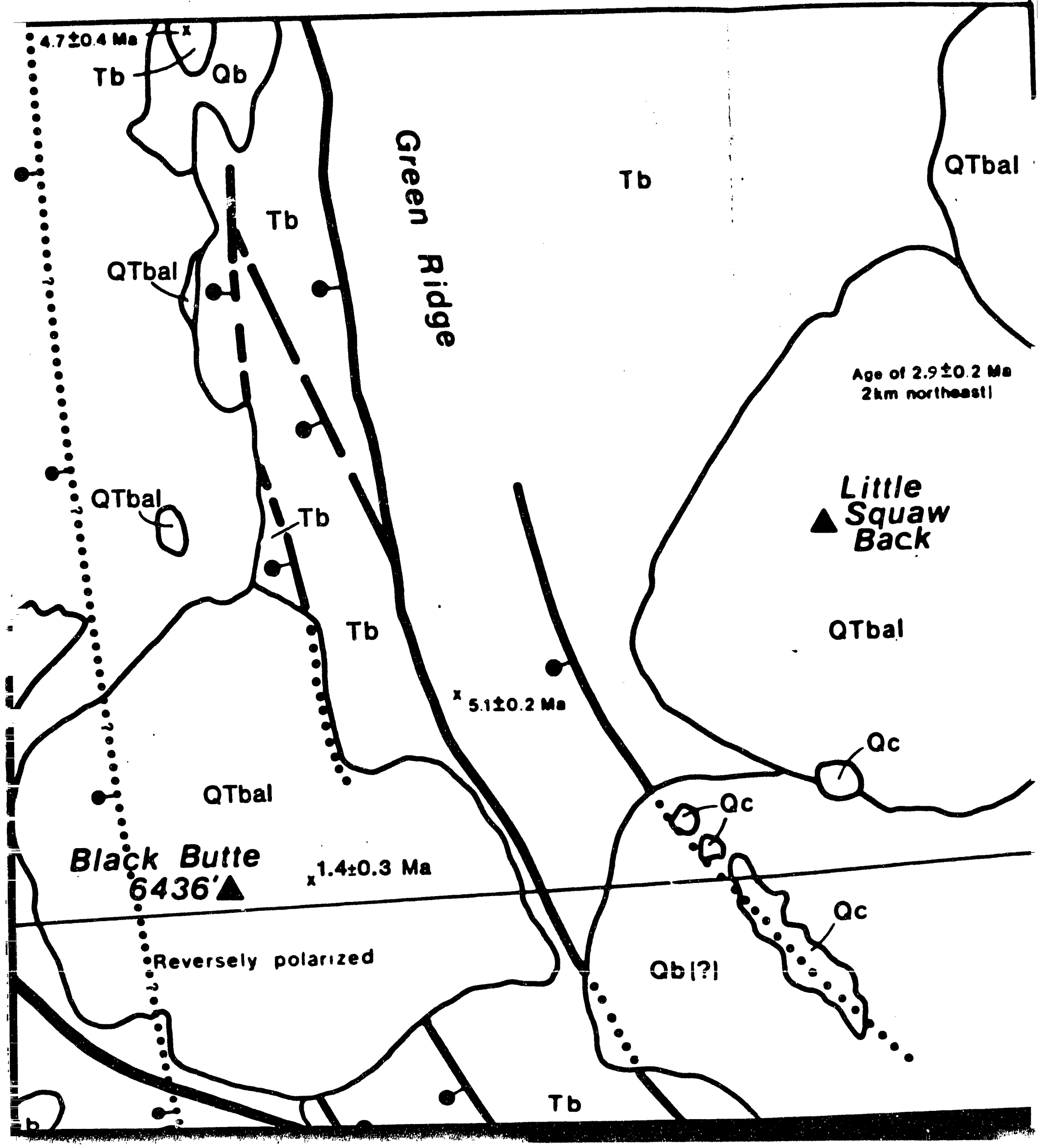




\section{JURCES OF THEE JON CASCADE SON AND \\ ON}

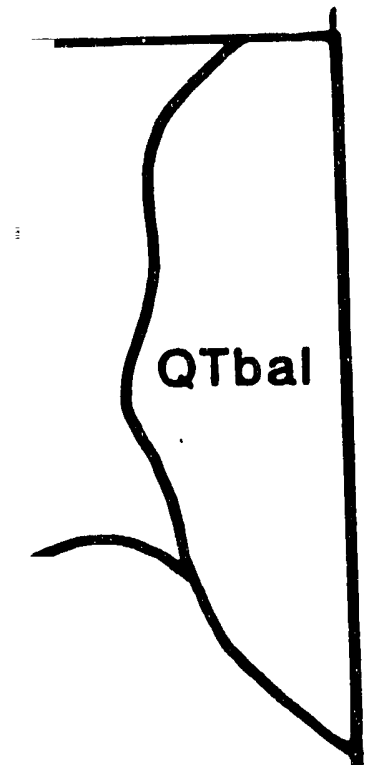

of $2.9 \pm 0.2 \mathrm{Me}$ m m northastl

1 4 He uaw bck

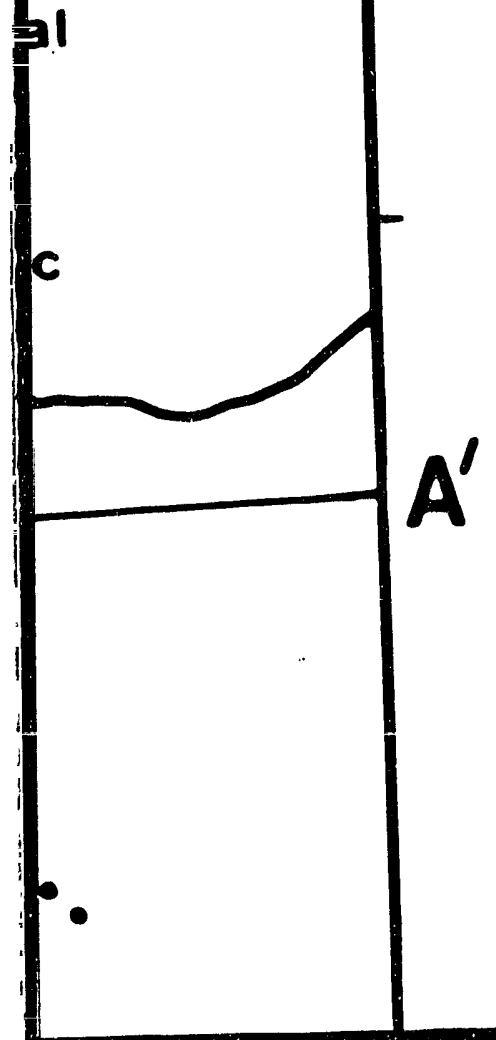

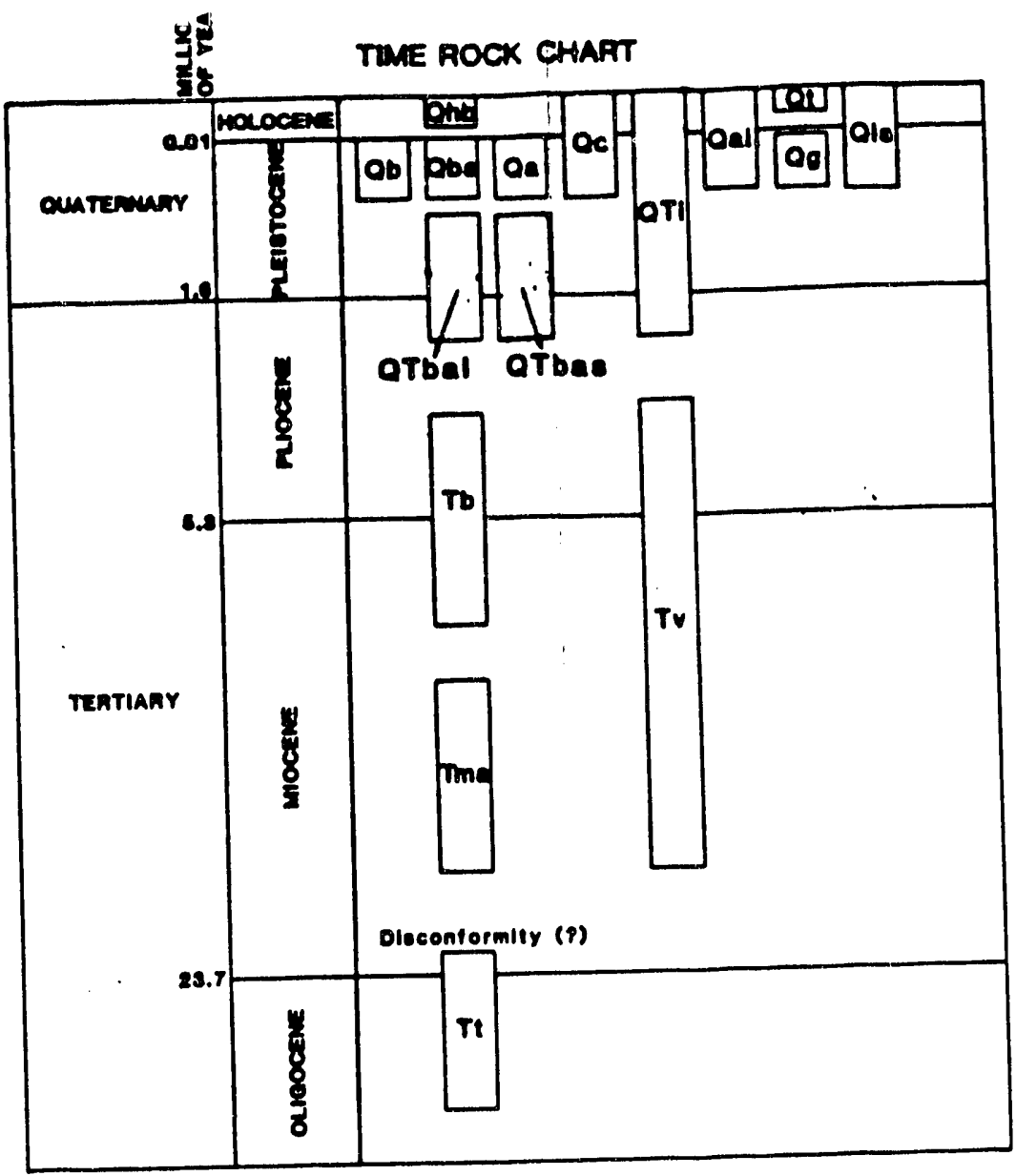

Dalee teken from Palmor (1eas).

Upoer and lower lime boundarles of rock unllo are echomalle.

\section{EXPLANATION}

SURFICLAL UNITS

Qal

Nluvium (Holocene and Pleistocene)-Sand, gravel, and silt in valley foors; east of longitude $1211^{\circ} 45^{\circ} \mathrm{W}$ includes flood deposits related to Pleistocene glaciation

Qls

Q

Qs

\section{Landslide (Holocene and Pleirlocene)}

Talus (Holocene and Pleirtocese)-Sheets and cones of coarse poorly soned andesite debris adjacent to Hayrick and Hoodoo Buttes

Glacial drin (Holoceme and Pleistacene)-Stratified and unstratified deposits of till; includes Canyon Creek, Jack Creek, and Abbot Butte formations of Scott (1977); lines of $x$ 's indicate moraine crests

\section{VOLCANIC UNITS}

Bosalt (Holocene)-Lava flows and breccia that form lava field Besaln (Holocene thass distribution of Holosene flows and vents west of Santiam Pass; distribution of holoxene hows and vents from Taylor (1968); Holocene basal is younger than Marase ash that is dated at $6,845 \pm 50{ }^{14} \mathrm{C}$-years
(1967) for ${ }^{14} \mathrm{C}$ ages in specific areas

Cones (Holocene and Pleistocene)-Cones and irregular Cinder cones (Holocene and Pleistoce ae)-Cones and irregular accumulations of cinders with lesser volumes of lave nows and intrusions; includes deeply eroded vem structures that bow crop intrusions; includes deeply eroded vem strolanic necks out as volcanic necks; cinder cones and volcanic nech hows (units sites of vents for the Holocene and Pleistocene lava nows (unith Qhb, Qbs, and Qb): Holocene cinder cones are shown with stipple pattern

Basaltic andesite (Pleistocene)-Lava flows and breceia: probably

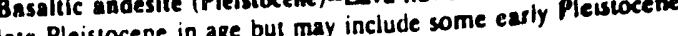
rocks; normal magnetic polarity

Rows or dornes Andesite (Pleistocene)-Large flat-lopped andesit mows or of of Hayrick Butte. Hogs Rock, and a small body monthearom and Hogg Rock: units commonly have glassy, colummo Racrated iops: age of Hose Rock is

REFER:

Amstrone R.L. Taylor, E.M.. He! dates for volcanic rocks, centr West, no. 13, p. 9.7.

Avramenko, W., 1981. Voleanusm Mountain centrd Oregon C. of Oregon, M.S. thesu, IS6

Bacor C.R. 1983, Enupive histor, ealdera Cuscade Range. U.SA mal Research, v. 18, p. 57.115 .

Black G.L Woller. N.M. and Fer: Cresceat Mounisin area Lna Depariment of Geologr and $M$

Couch, R.W. Pits, G.S. Bramar 1 graviry anomaly map and coms Cuscade Mounum Range. nor: Geology and Mineral Indusine 1:250,000.

Dane, E.I. 1900. The seology and High Cascades volano in cen of Oregon. M.S. inesis 138 p

Fiebelkorn, R.B., Walker, G.W.. A J.G. 1982, Index to K.As age U.S. Geological Survey Open.

Palmer, A.R., 1983. The Decade I Geologic Time Scale: Geolos

Priest, G.R. Barear. K.E. Blact. Duncar RA. Evank J. Cok Duncal Reut TEC Koros , Th R.H. Mooney, W.D. Rown Weaver, CS. Woller. N.M. "
the thermal repons and Furs phe of o propen

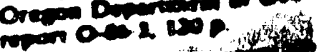

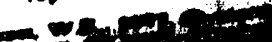




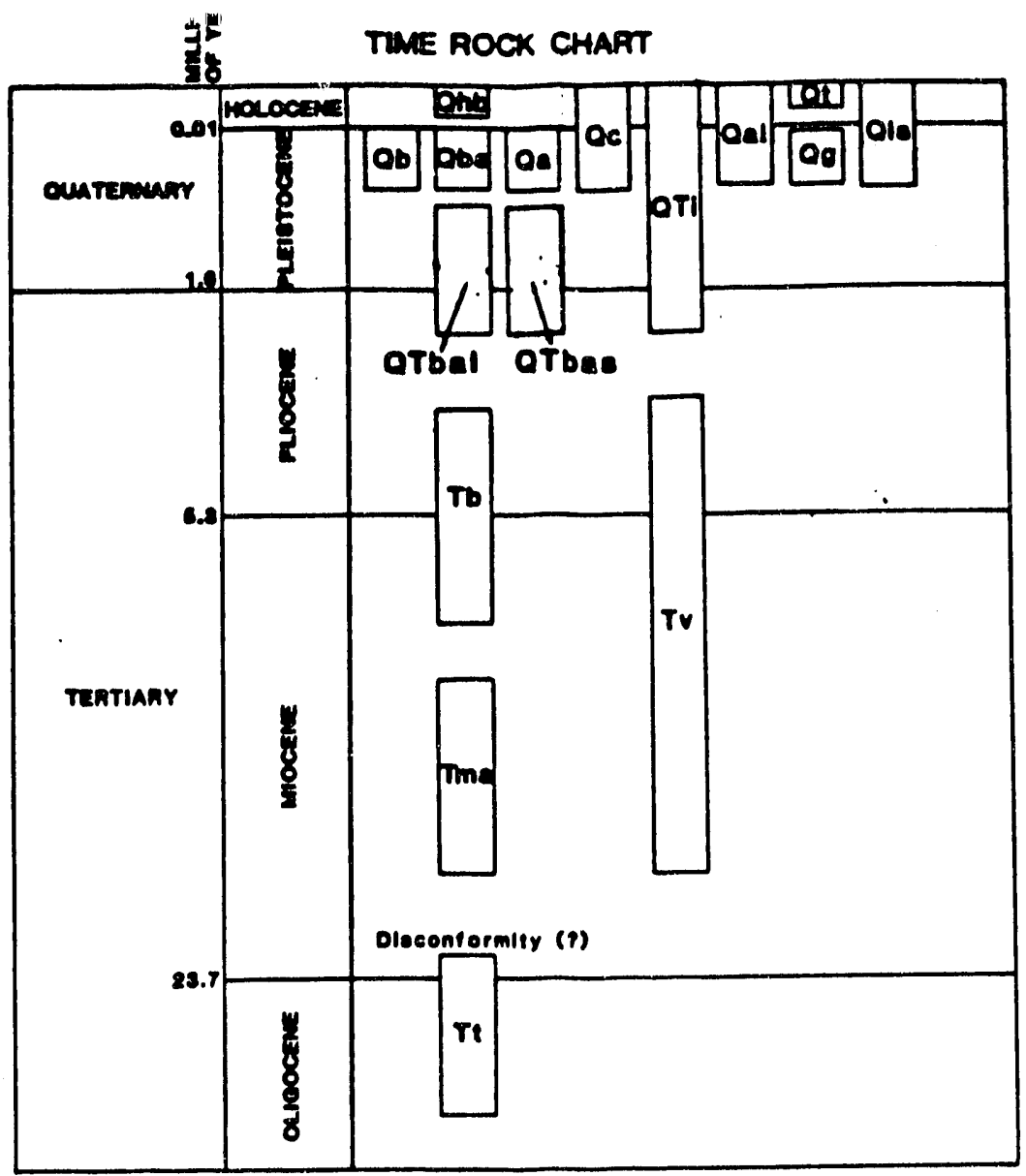

Defee taken Irom Palmor (19es).

Upper and lower lime boundarles of rock unile are echometic.

\section{EXPLANATION}

\section{SURFICLAL UNITS}

Nluvium (Holocene and Pleistocese)-Sand, gravel, and silt in valley floors: east of longitude $121^{\circ} 49^{\circ} \mathrm{W}$ includes flood deposits related to Pleistocene glacration

Q1s

Landslide (Holocene and Pleistocene)

Q

Talus (Holocene and Pleislocene)-Sheets and cones of coarse, poorly soned andesite debris adjacent to Hayrick and Hoodoo Buttes

Q. Glaciel drin (Holocens and Pleistocene)-Stratified and unstratified deposits of till; includes Canyon Creek, Jack Creek, and Abbot Butte formations of Scoll (1977); lines of x's indicate moraine erests

\section{VOLCANIC UNITS}

Rasalt (Holocene)-.Lava flows and breccia that form lava field west of Santiam Pass; distribution of Holocene flows and vents from Taylor (1968); Holocene basalt is younger than Mazama ash that is dated at 6,845 550 "C C-years (Bacon, 1983); see Taylor (1967) for ${ }^{14} \mathrm{C}$ ages in specific areas

Oc Cinder cones (Holocene and Pleistoxene)-Cones and irregular accumulations of cinders with lessir volumes of lava hows and out as volcanic necks; cinder cones and volcanic necks mark the sites of vents for the Holocene and Pleistocene lava hows (units Qfib, Qba, and Qb); Holocene cinder cones are shown with a stipple pattern

Bassttic andesite (Pleistocene)-.Lava nows and breccia: probably late Pleistocene in age but may include some early Pleistocene rocks; normal magnetic polarity

Andesire (Pleistocene)-Large flat-lopped andesite flows or domes of Hayrick Butie. Hogg Rock, and a small body northeast of Hoge Rock: units commonly have glassy, columnar margins and glaciated tops: age of Hogg Rock is $0.09 \pm 0.02 \mathrm{Ma}$

\section{REFERENCES CITED}

Armstrone R.L., Taylor, E.M., Hales, P.O., and Parker, D.J., 1975, K-Ar dates for volcanic rocks, central Cascade Range of Oregon: Isochron/. West, no. 13, p. 5.7 .

Avramenko, W., 1981, Volcanism and structure in the vicinity of Echo Mountain, central Oreson Cascade Range: Eugene, Oreg., University of Oregon, M.S. thesis, $156 \mathrm{p}$.

Bacon, C.R., 1983, Enuptive history of Mount Mazama and Crater Lake caldera, Cascade Range, U.S.A.: Joumal of Volcanolory and Geother. mal Research, v. 18, p. 57-115.

Black, G.L. Woller, N.M., and Ferns, M.L., 1987, Geologic map of the Crescent Mountain area, Linn County, Oregom, scale 1:62500: Oregon Deparument of Geolory and Mineral Industries Map GMS-17.

Couch, R.W., Pitss, G.S., Braman, D.E., and Gemperle, M., 1981, Free-air gravity anomaly map and complete Bouguer gravity anomaly map. Cascade Mountain Range, northern Oregon: Oregon Department of Geology and Mineral Industries Geological Map Series GMS.15, scale 1:250,000.

Davie, E.1. 1980. The geology and petrology of Three Fingered Jack, a High Cascades voleano in central Oregon: Eugene, Oreg., University of Oregon, M.S. thesis, 138 p.

Fiebelkorn, R.B., Walker, G.W., MacLeod, N.S., McKee, E.H., and Smith, S.G. 1982 Index $10 \mathrm{~K}$.As age determinations for the state of Oregon: U.S. Geological Survey Open-File Report 82-596, 40 p.

Palmer, A.R., 1983, The Decade of North American Geology 1983 Geologic Time Scale: Geology, v. 11, p. 503-504.

Priest, G.R., Bargar, K.E., Black, G.R., Blackwell, D.D., Couch, R.A, Duncan R. Evans, J., Goldstein, W., Haimson, B.C., Hughes, S., lyet. M., Keith, T.E.C. Kormec, M.A., Laul, J.C., Levy, S., Mariner, R.H. Mooney, W.D. Rowley, Jn Sherrod, D.R., Smith, M., Waibel, A, Weaver, C.S. Woller, N.M., and Wright, P.M., 1987a, Investigation of the thermal regime and geciogic history of the Cascade volcanic arc: First phase of a program for scientific drilling in the Cascade Range: Oregon Department of Geology and Mineral Industries Open-File repon 0.86-3. $120 \mathrm{p}$. 


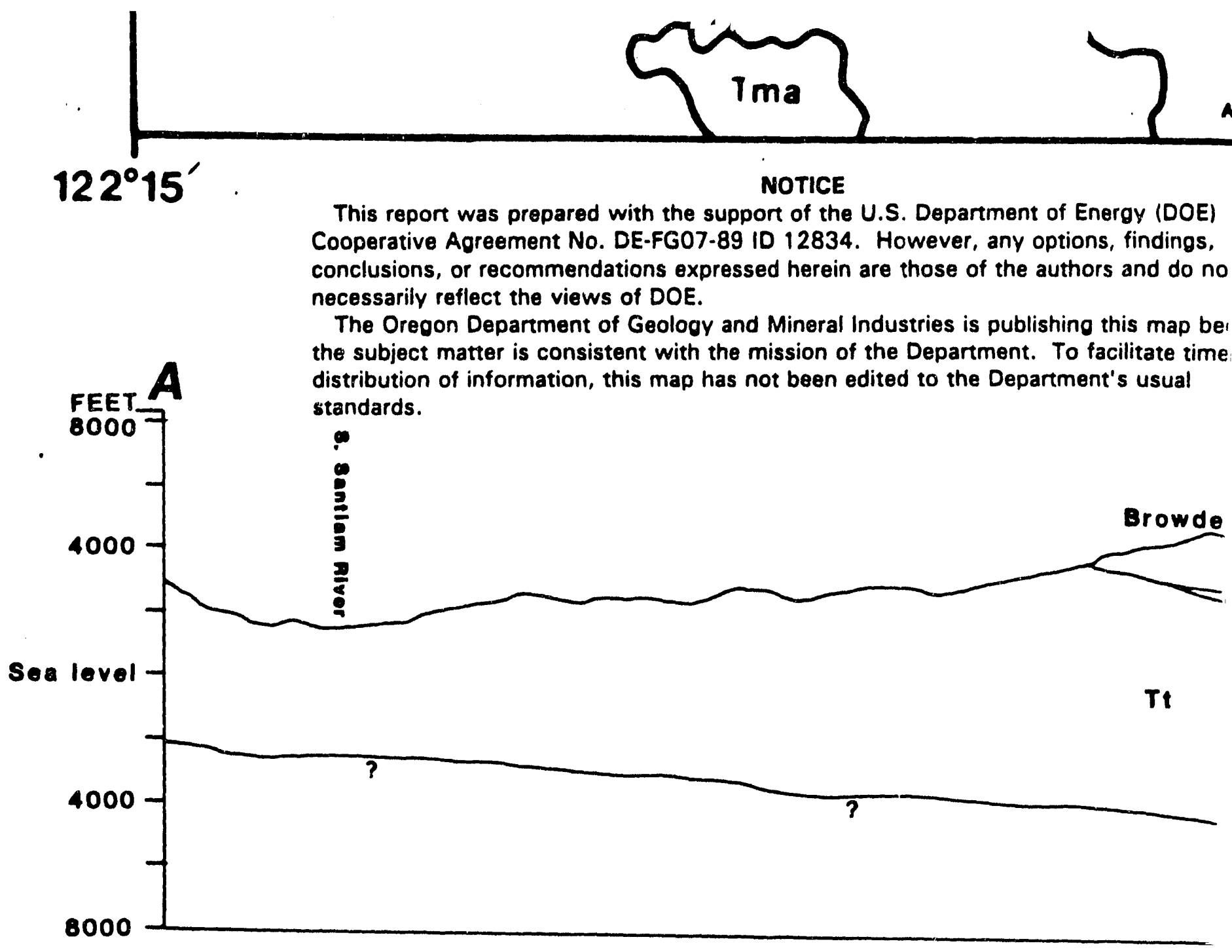




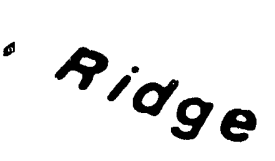

Age of $51 \pm 01$ me $4 \mathrm{~km}$ soulhl

ieroy (DOE)

$s$, findings,

is and do not

this map because

acilitate timely

it's usual

LOCATION MAP

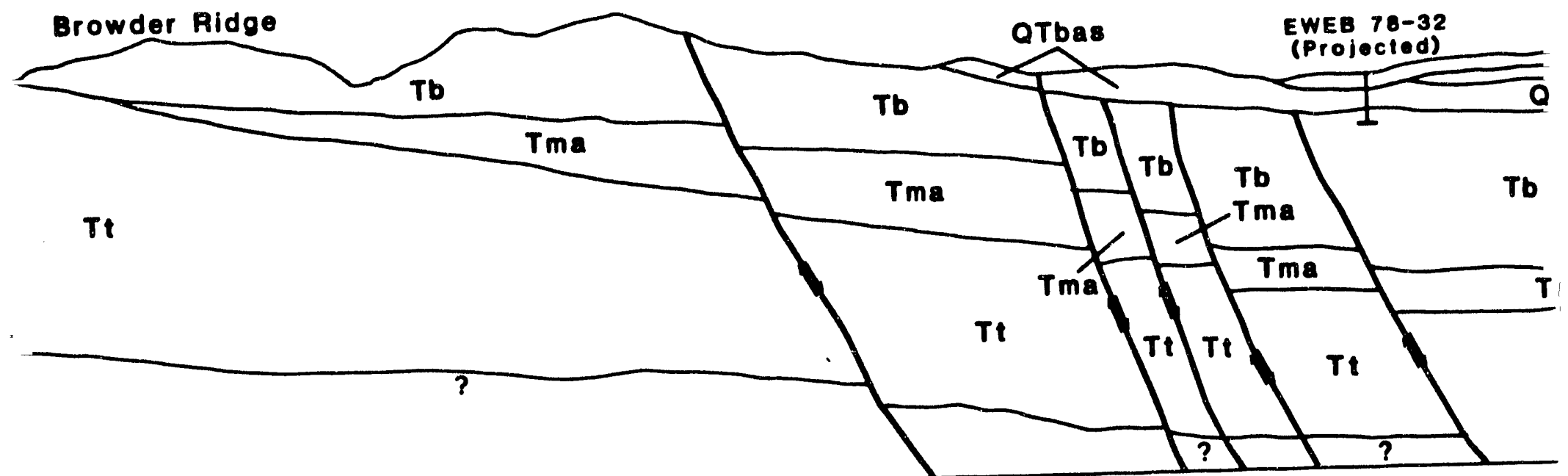



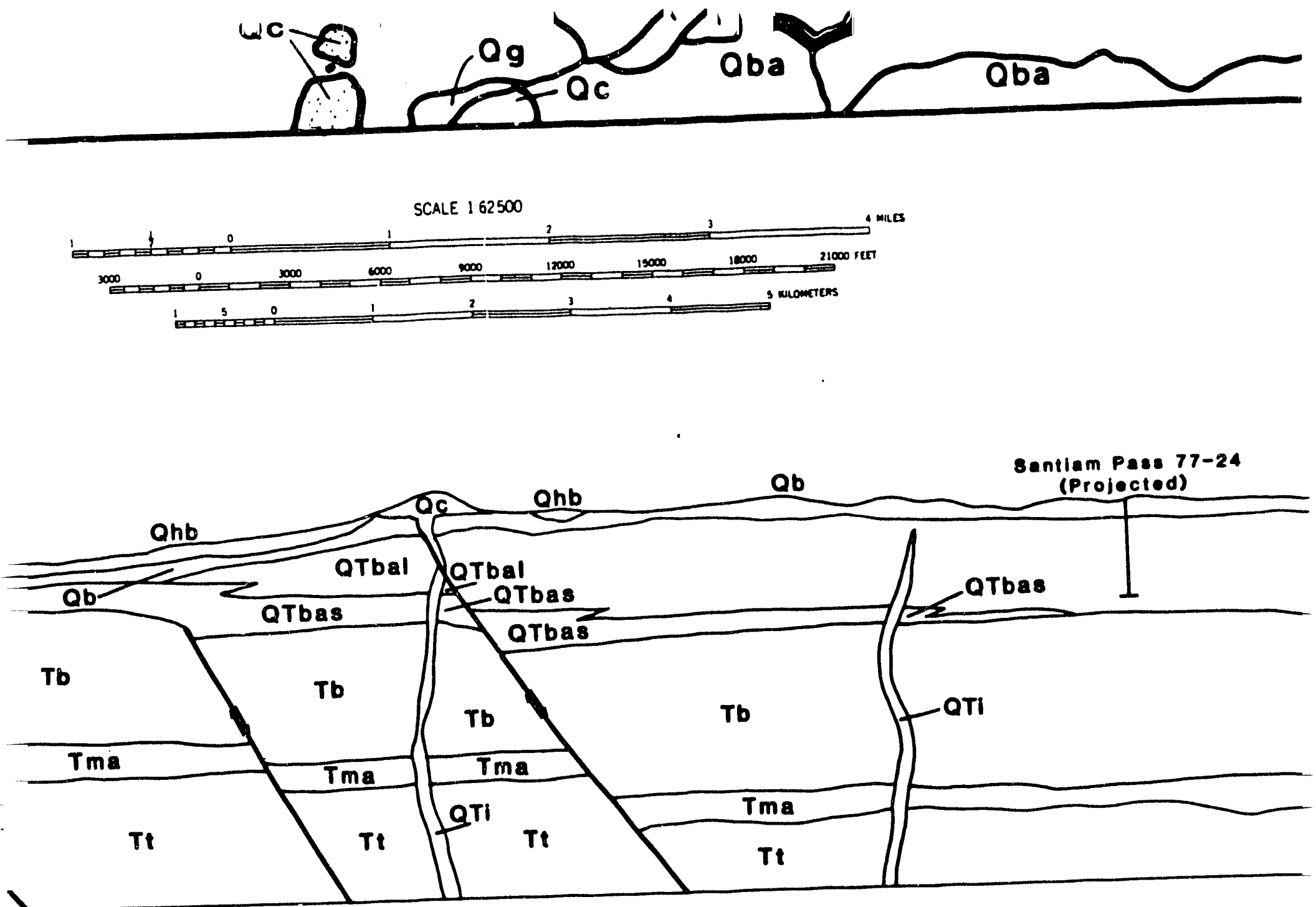

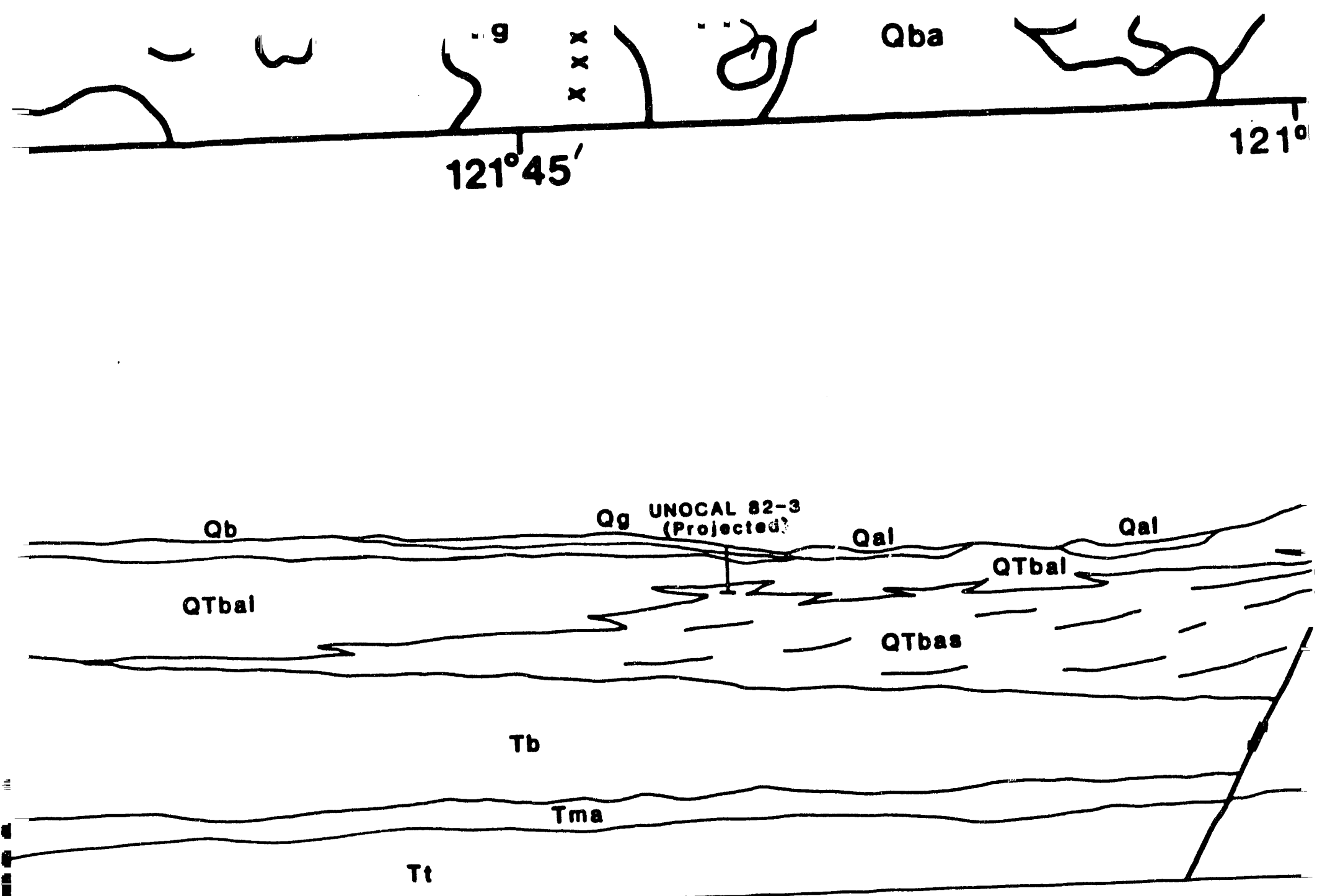


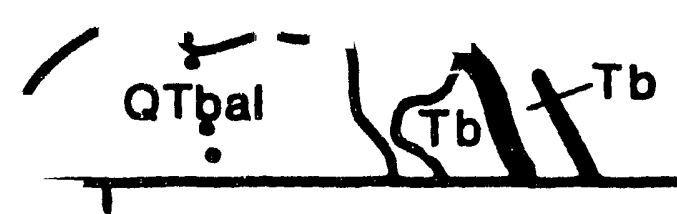

$21^{\circ} 39^{\prime}$ Map compiled by David Sherrod, cross-section by B. Hill and D. Sherrod. Geology from Taylor (1968, 1981), Avramenko (1981), Davie (1981), Black et al., (1987), and unpublished map data of G.W. Walker (1984). Isotopic age data from Taylor (1968, 1981), Armstrong et al., (1975), Fiebelkorn et al., (1981), unpublished data of B. Dalrymple (1982), and this report. Gravity cross section by D. Sherrod, based on data of Thiruvathukal et al., (1970), and Couch et al., (1981).

\section{GEOLOGIC CROSS SECTION}

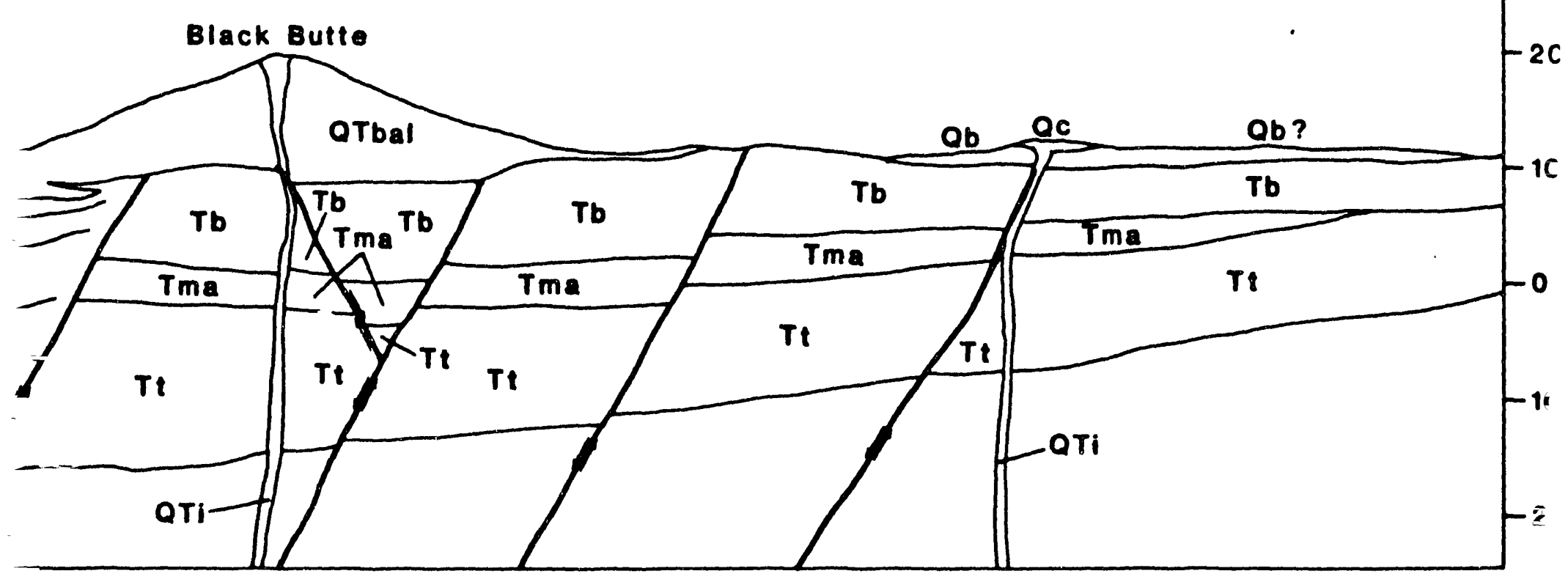




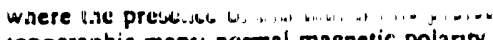

topographic maps; normal magnetic polarity

QTbal Basaltic andesite and basall (Pleistocene and Pliocene)-Lave flows and breccia; includes the lasge shield volcanoes of Black Butte and Litule Squawback: age probably ranges from about 0.7 to about $3 \mathrm{Ma}$; reverse and normal magnetic polarity; commonty interbedded with subordinate anounts of fluvial, volcaniclastic, and lacustrine sedimentary rocks

QTbas Volcaniclastic racks (Pleistocene and Pliocene)--Debris-flow deposits, coarse- 10 fine-grained volcanic conglomerate and sandstone, fine-grained and locally diatomaceous lacustrine mudstone; commonly interbedded with subordinate amounts of basalt and basaltic andesite flows and breccias

Tb Basalt and basaltic andesite (Pliocetue and Miocene)-Lava flows and breccia; locally interbedded with volcaniclastic sedimentary rocks, which increase in abundance at the eastern and western margins of the map area; includes Iron Mountain and BrowderBunchgrass formations of Avramenko (1981), and Deschutes Formation of Smith (1986); K.As ages range from about 4- 107.

\section{METERS}

2000 $\mathrm{Ma}$ but the base of the unit is probably older; unit iacludes rocks ranging in age from about $3 \mathrm{Ma}$ to about $8 \mathrm{Ma}$; age is Pliocene to late Miocene

TV Vents (Pllocene and Mlocene)-Plugs. cinders, and lava flows that form deeply eroded vent complexes

1000

Tma Andesite (Miocene)-Andesite and basalic andesite lava flows and breccia; age is mostly middle Miocene but may include rocks of late Miocene age

$\mathbf{0}$

In Ash-flow turf (Mlocene and Oliecene)-Tuff and lapilli wff with lesser lava flows, domes, and intrusions; composition is poorly known but petrography indicates probable compositions ranging from andesite to rbyodacite

\section{INTRUSIVES}

QTI Intrusions (Holocene, Pleistoceme, and Pliocene)-Dikes and plugs; shown mainly on cross section

\section{MAP SYMBOLS}

Smith, G.A., 1986, Stratigraphy, sedimentology and petrology of Neogene rocks in the Deschutes Basin, central Oregon: A record of cominenta margin volcanism and its influence on huvial sedimentation in an arc. adjacent basin: Corvallis, Oreg., Oregon State University, Ph.D. dissertation, $467 \mathrm{p}$.

Taylor, E.M., 1967, Recent volcanism berween Three Fingered Jack and North Sister, Oregon Cascade Range: Pullman, Wash., Washington State Unuversity, Ph.D. dissertation, 84 p.

1981, Central High Cascade roadside geology--Bend, Sisters, McKenz Pass, and Santiam Pass, Oregon: in D.A. Johnston and J.Donnelly- Nolar eds., Guides to some volcanic terranes in Washington, Idaho, Oregon and Northern California. U.S. Geological Survey Circulas 838 p. 55.58.

Thiruvathukal, J.V., Berg, J.W., Jr., and Heinrichs, D.F., 1970, Regional gravity of Oregon: Geological Society of America Bulletin, v, 81, p. 725.738.

Fault--Dashed where inferred; dotted where concealed; ball and bas on downthrown side.

$x$
$\times \times$ Crests of Individual eoraleses
Locations of wountain peaks
E Locations of K.Ar datiag samples
L cocations of temperaturegradieat boles 

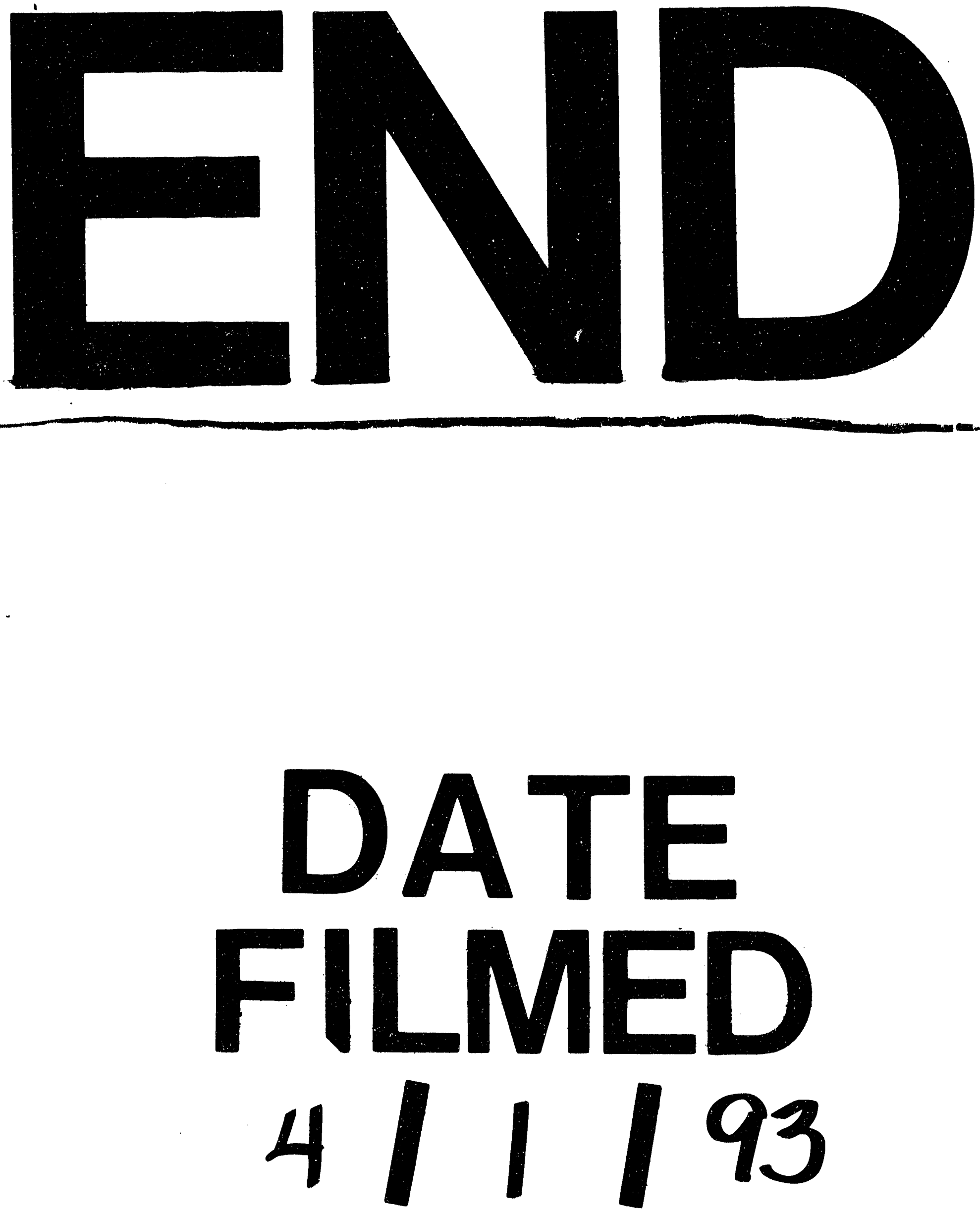
